\title{
AVALIAÇÃO DA RESISTÊNCIA E MÓDULO DE ELASTICIDADE DE OSSO MINERALIZADO E DESMINERALIZADO PELOS TESTES DE MICROTRAÇÃO
}

\author{
JEFFERSON TOMIO SANADA
}

Dissertação apresentada à Faculdade de Odontologia de Bauru da Universidade de São Paulo, como parte dos requisitos para a obtenção do título de Mestre em Odontologia - Área de Reabilitação Oral. 


\section{AVALIAÇÃO DA RESISTÊNCIA E MÓDULO DE ELASTICIDADE DE OSSO MINERALIZADO E DESMINERALIZADO PELOS TESTES DE MICROTRAÇÃO}

\section{JEFFERSON TOMIO SANADA}

Dissertação apresentada à Faculdade de Odontologia de Bauru da Universidade de São Paulo, como parte dos requisitos para a obtenção do título de Mestre em Odontologia - Área de Reabilitação Oral.

Orientador: Prof. Dr. Accácio Lins do Valle 


Sa51a Sanada, Jefferson Tomio
Avaliação da resistência e módulo de elasticidade de osso
mineralizado e desmineralizado pelos testes de microtração /
Jefferson Tomio Sanada./ -- Bauru, 2007.
112 p.: il.; 30cm
Dissertação. (Mestrado) -- Faculdade de Odontologia de
Bauru. Universidade de São Paulo.
Orientador: Prof. Dr. Accácio Lins do Valle

Autorizo, exclusivamente para fins acadêmicos e científicos, a reprodução total ou parcial desta dissertação/tese, por processos fotocopiadores e outros meios eletrônicos.

Assinatura

Data de aprovação pela Comissão de Ética no Ensino e Pesquisa em Animais: 06 de outubro de 2004.

Número do processo: 22/2004.

A cópia do parecer de aprovação encontra-se no capítulo "Anexo" 


\section{DADOS CURRICULARES}

\section{JEFFERSON TOMIO SANADA}

Nascimento

Filiação

$2000-2003$

$2005-2007$

Associações
25 de Janeiro de 1980

Londrina - PR

Edson Yoshinobu Sanada

Iracema Kimi Muraguchi Sanada

Curso de Graduação em Odontologia Faculdade de Odontologia de Bauru USP.

Curso de Pós-Graduação em Reabilitação Oral em nível de Mestrado, na Faculdade de Odontologia de Bauru -USP.

APCD - Associação Paulista de Cirurgião

Dentista.

$\mathrm{SBPqO}$ - Sociedade Brasileira de Pesquisa Odontológica. 


\section{Dedicatória}

A Deus que sempre me guiou para os caminhos certos da vida.

Aos meus pais, Edson e Iracema, fundamentais nos momentos mais difícies da minha vida, sempre acreditando, confiando e compartilhando com a idealização dos meus sonhos. Amo vocês com toda a força deste mundo, alicerces na minha vida, essa é uma conquista nossa.

A todos os meus familiares, pelo apoio sempre dado nas minhas decisões, principalmente, minha Tia Eunice e Neusa, que nunca negaram esforços na minha formação.

Ao meu amor, Ingrid, palavras neste momento seriam pouco perto do que eu sinto, você sabe muito bem o que eu passei para chegar aqui, viveu e vive ao meu lado dando sempre força, paz, amor e compreesão, nunca esquecerei de tudo isso. Essa conquista também é sua.

Este trabalho dedico a vocês, pessoas fundamentais neste trabalho e na minha vida. 


\section{Agradecimento Especial}

Ao Prof. Dr. Accácio Lins do Valle, um mestre e amigo que em todos os momentos da minha vida acadêmica me orientou e guiou meus pensamentos. Devo muito dos meus conhecimentos e da minha maturidade a este grande orientador, ou melhor, um grande amigo. Agradeço pela sua paciência e dedicação dada durante estes anos de convívio. 


\section{Agradecimentos}

Ao Prof.Dr.Luiz Fernando Pegoraro, exemplo de sensatez, pela condução de seus ensinamentos e princípios.

Prof.Dr. GersonBonfante, pela disponibilidade e valiosas orientações e exemplo de caráter e senso critico.

Ao Prof.Dr.José Henrique Rubo, pela transmissão de conhecimentos e convívio. Pelo exemplo de uma pessoa serena e disciplinada.

Ao Prof.Dr. Paulo César Rodrigues Conti, pela responsabilidade e transmissão de conhecimento.

Ao Prof. Dr. Paulo Martins, pela amizade e companheirismo desde a graduação.

Aos Profs. Drs. Salvador e Lucimar, pelos seus ensinamentos desde a graduação e que sou grato para sempre, pessoas de grande coração.

Ao Prof. Dr. Vinícius Porto, pela amizade, estima e exemplo.

Ao Prof. Dr. Ricardo Marins de Carvalho, mesmo com pouco tempo de departamento soube demonstrar todo o seu conhecimento, agradeço pela sua amizade e exemplo de vida.

Ao Prof. Dr. Pedro, o pouco tempo de convívio não me impede de falar da pessoa boa e prestativa que você é. 
Aos Professores do Departamento de Prótese, Renato, Wellington e Carlos Araújo por tudo que me ensinaram,

Aos amigos de mestrado, Adriana, Ana Paula, Daniel Bayardo, Daniel Sartorelli, Fernando, Flora, Gabriela, Luciana, Paola, Rafael, Valéria. Vocês sempre estarão guardados nas minhas lembranças, especialmente DUDU, ROMÃO e THIAGO, amigos para todos os momentos.

Aos amigos do doutorado "novo”, Estevam, Kátia, Livia, Mikaela, Patrícia, Rodrigo, Sadam, pelas orientações e conselhos.

Aos amigos do doutorado "antigo", Eduardo Ayub, Jefferson, Leila, Paulo Fukashi, Paulo Rosseti, Rafael, Ricardo, Tatiane.

Aos doutorandos da Periodontia, Marly, Ana Lúcia, Marcio Taga e Andréia, principalmente na ajuda em nossas clínicas.

Aos ex-estagiários, e hoje colegas de mestrado, Cíntia, Daniel, Gustavo, João Paulo, José Luiz (Zezo), Marcelo, Paulo Maurício, pela disponibilidade em sempre nos auxiliar e pelo convívio, e principalmente o Fábio (Budinha) amigo de muito trabalho.

A todo amigos mestrandos de 2005/2006, especialmente aos membros da APG - Bauru, os quais dividimos momentos inesquecíveis.

A Daniela Viveiros, amiga que sempre me ajudou e tenho grande estima.

Aos funcionários da biblioteca pela solicitude e profissionalismo. 
Aos funcionários do Departamento, Cláudia, Deborah, Rivanildo, Marcelo Giatti e Valquíria, pelo profissionalismo e gentileza em todos os momentos.

Aos funcionários do Centro Integrado de Pesquisa (CIP), principalmente a Dona Neusa e Marcelo que sempre ajudaram e auxiliaram nos momentos importantes dessa pesquisa.

Aos funcionários do Biotério da FOB, pela compreensão, calma e ajuda com uma das peças fundamentais deste trabalho que foram os meus animais.

Aos funcionários da Secretária de Pós-Graduação da FOB, pela atenção e sempre disponibilidade, obrigado Giane, Letícia e Margareth.

Aos funcionários da Clínica de Pós-Graduação da FOB, pela paciência e calma nas clínicas “demoradas”, obrigado Cleusa, Hebe e Du.

À Faculdade de Odontologia de Bauru - USP, representada por seu Diretor

Prof. Dr. Luiz Fernando Pegoraro, e à sua Comissão de Pós-Graduação, representada pelo Prof ${ }^{a}$.Dr ${ }^{a}$. Maria Aparecida de Andrade Moreira Machado.

Ao $\mathrm{CNpQ}$, pelo apoio financeiro tornando exeqüível este trabalho.

A todas as pessoas que de alguma maneira, direta ou indiretamente, contribuíram com esta conquista.

Meus sinceros agradecimentos. 


\section{SUMÁRIO}

DEDICATÓRIA E AGRADECIMENTOS ii

LISTA DE FIGURAS ix

LISTA DE TABELAS Xii

LISTA DE ABREVIATURAS E SÍMBOLOS xiv

RESUMO $\quad \mathbf{x v i}$

1 - INTRODUÇÃO

2 - REVISÃO DA LITERATURA 9

2.1 - Tecido ósseo

2.2 - Enxerto ósseo

2.3 - Testes experimentais em calvária de ratos

2.4 - Comportamento mecânico dos ossos

3 - PROPOSIÇÃO

3.1 - Objetivo geral

3.2 - Objetivo específico

4 - MATERIAL E MÉTODOS

4.2 - Animais

4.2 - Sacrifício dos animais

4.3 - Grupo mineralizado

4.3.1 - Preparo das peças para teste de microtração

4.3.2 - Teste de microtração

4.3.3 - Preparo das peças para teste de módulo de elasticidade

4.3.4. - Teste de módulo de elasticidade

4.4 - Grupo desmineralizado

4.4.1 - Preparo das peças para teste de módulo de elasticidade e microtração 
4.4.2 - Teste de módulo de elasticidade e microtração

4.5. - Análise estatística

5 - RESULTADOS

5.1 - Microtração

5.2 - Módulo de elasticidade

6 - DISCUSSÃO

7 - CONCLUSÕES

89

ANEXO

93

REFERÊNCIAS

97

ABSTRACT

109 


\section{LISTA DE FIGURAS}

Pág.

Figura 1 Desenho teórico representativo das regiões de deformação elástica e plástica observadas em uma curva teórica tensão $x$ deformação.

Figura 2 Ratos albinos da linhagem Wistar (Rattus norvegicus) do Biotério Central da Faculdade de Odontologia de Bauru USP

Figura 3 Esquema da calvária de ratos. A área em destaque referese às duas parietais do animal

Figura 4 Esquema das divisões dos grupos e sub-grupos.

Figura 5 Drogas utilizadas no procedimento de sacrifício dos animais, 57 Dopalen $^{\circledR}$ e Anasedan ${ }^{\circledR}$ (SESPO - Divisão vetbrands saúde animal, Jacareí, São Paulo, Brasil).

Figura 6 Esquema para o preparo do espécime. a)calota craniana após a dissecação pronto para o preparo do corpo de prova. b)Corpo de prova divido para confecção do espécime. c)padronizado nas dimensões adequadas para teste mecânico (10x3mm), seta azul demonstrando a região que foi utilizada para mensuração da secção transversal (largura). 
Figura 7 Máquina de ensaio Vitrodyne, modelo V1000 (Liveco Inc., 59 Burlington, VT).

Figura 8 Esquema para o preparo do espécime. a) calota craniana 60 após a dissecação pronto para o preparo do corpo de prova. b) Corpo de prova divido ao meio para confecção do espécime. c) padronizado nas dimensões adequadas para teste mecânico (10 × $3 \mathrm{~mm})$.

Figura 9 Desenho do espécime para o teste de módulo de 62 elasticidade, observar os ângulos vivos criados para conseguir determinar o tamanho inicial da região do espécime que sofrerá a tensão.

Figura 10 Esmalte de unha para proteção da desmineralização pelo 63 EDTA 0,5M das extremidades do espécime.

Figura 11 Esquema do teste de módulo de elasticidade sob imersão de 63 solução aquosa.

Figura 12 Análise estatística pelo programa SigmaStat 3,1. Teste T de

Studentavaliando as Médias, Desvio Padrão, Grau de Liberdade, Intervalo de Confiabilidade e Diferença Estatísicas 
Figura 13 Representação gráfica dos valores médios, em MPa, da 71 Resistência a Tração para cada grupo. As barras dentro das colunas são representações do desvio padrão.

Figura 14 Análise estatística pelo programa SigmaStat 3,1. Teste T de

Student Avaliando as Médias, Desvio Padrão, Grau de Liberdade, Intervalo de Confiabilidade e Diferença Estatísicas.

Figura 15 Representação gráfica dos valores médios, em $\mathrm{MPa}$, do 76 Módulo de Elasticidade para cada grupo. As barras dentro das colunas são representações do desvio padrão.

Figura 16 Representação gráfica de um espécime de cada sub-grupo (mineralizado e desmineralizado) dos valores de tensão em relação ao deslocamento do espécime (\%). 


\section{LISTA DE TABELAS}

Pág.

Tabela 1 Valores individuas para cada espécime do sub-grupo

mineralizado frente ao teste de microtração, ilustrando a área da secção transversal $\left(\mathrm{cm}^{2}\right)$, tensão máxima $(\mathrm{KgF})$, tensão máxima sobre a área $\left(\mathrm{KgF} / \mathrm{cm}^{2}\right)$ e tensão $(\mathrm{MPa})$.

Tabela 2 Valores individuas para cada espécime do sub-grupo 69 desmineralizado frente ao teste de microtração, ilustrando a área da secção transversal $\left(\mathrm{cm}^{2}\right)$, tensão máxima $(\mathrm{KgF})$, tensão máxima sobre a área $\left(\mathrm{KgF} / \mathrm{cm}^{2}\right)$ e tensão (MPa).

Tabela 3 Valores individuas para cada espécime do sub-grupo mineralizado frente ao teste de Módulo de Elasticidade, ilustrando o Módulo de Elasticidade (MPa), Tensão (MPa), Deformação (\%) e a área de secção transversal $\left(\mathrm{cm}^{2}\right)$.

Tabela 4 Valores individuas para cada espécime do sub-grupo desmineralizado frente ao teste de Módulo de Elasticidade, ilustrando o Módulo de Elasticidade (MPa), Tensão (MPa), Deformação (\%) e a área de secção transversal $\left(\mathrm{cm}^{2}\right)$. 
Tabela 5 Valores médios do osso humano (adaptação de

BILEZIKIAN; RAISZ; RODAN $\left.{ }^{14}, 2002\right)$

Tabela 6 Estudos que avaliaram de alguma forma o módulo de elasticidade. 


\section{LISTA DE ABREVIATURAS E SÍMBOLOS}

$\begin{array}{ll}\text { BMP } & \text { Proteína morfogéntica óssea (bone morphogenic proteins) } \\ \text { hBMP } & \text { Proteína morfogenética óssea humana } \\ \text { rhBMP } & \text { Proteína morfogenética óssea recombiante humana } \\ \text { HIV } & \begin{array}{l}\text { Vírus da Imunodeficiência Humana (Human Imunnedeficiency } \\ \text { Virus) }\end{array} \\ \text { FDBA } & \text { Enxerto alógeno de osso liofilizado } \\ \text { DFDBA } & \text { Enxerto alógeno de osso liofilizado desmineralizado } \\ \text { RGO } & \text { Regeneração Guiada Óssea } \\ \text { RTG } & \text { Regeneração tecidual guiada } \\ \text { TGF } & \text { Fator de crescimento transformante } \\ \text { FGF } & \text { Fator de crescimento de fibroblasto } \\ \text { IGF } & \text { Fator de crescimento similar a insulina } \\ \text { PDGF } & \text { Fatores de crescimento derivados das plaquetas } \\ \text { FCDM } & \text { Fator de crescimento derivados dos macrófagos } \\ \text { HA } & \text { Ácido etilenodiamino tetra-acético } \\ \text { PTI } & \text { Hidroxiapatita } \\ \text { PTFE-e } & \text { Prótese total imediata } \\ \text { MHPC } & \text { Tetrafluoretileno expandido } \\ \text { PBBM } & \text { Metil-hidroxi-propil-celulose } \\ \text { DBM } & \text { Osso bovino poroso mineral } \\ \text { TCP } & \text { Matriz óssea desmineralizada } \\ \text { ACS } & \text { Trifosfato de cálcio } \\ \text { DVS } & \text { xinil-estireno } \\ \text { EDA } & \text { Áta de colágeno absorvível } \\ & \end{array}$




\begin{tabular}{|c|c|}
\hline rhTGF -ß1 & $\begin{array}{l}\text { Fator de transformação de crescimento humano recombinante } \\
\text { B }\end{array}$ \\
\hline PRP & Plasma rico em plaqueta \\
\hline hPDLF & Fibroblasto do ligamento periodontal humano \\
\hline MMT & 3-(4,5-dimetil-tiazole-2yl)-2,5-difenil brometo de tetrazolio \\
\hline RT-PCR & Reação de cadeia de transcrição-polimerase reversa \\
\hline ALPase & Atividade de fosfatase alcalina \\
\hline FFSS & Sistema de selamento de fibina-fibronectina \\
\hline $\mathrm{cm}$ & Centímetro \\
\hline $\mathrm{mm}$ & Milímetro \\
\hline $\mathrm{cm}^{2}$ & Centímetro quadrado \\
\hline$\mu \mathrm{m}$ & Micrometros \\
\hline $\mathrm{mg} / \mathrm{mL}$ & Miligramas por mililitros \\
\hline $\mathrm{g} / \mathrm{cm}^{3}$ & Grama por centímetro cúbico \\
\hline $\mathrm{KgF}$ & Quilograma força \\
\hline $\mathrm{MPa}$ & Megapaschal \\
\hline GPa & Gigapaschal \\
\hline M & Molaridade (relação molar) \\
\hline$<$ & Menor \\
\hline$>$ & Maior \\
\hline$=$ & Menor ou igual \\
\hline$=$ & Maior ou igual \\
\hline B & Beta \\
\hline$\%$ & Porcentagem \\
\hline $\mathrm{p}$ & Nível de significância \\
\hline TM & Marca registrada (Trade market) \\
\hline
\end{tabular}




\section{RESUMO}

A perda do osso alveolar como resultado de doença periodontal ou secundariamente à cirurgia são fontes de inúmeras complicações para os cirurgiões dentistas, e a solução para tal problema se baseiam em procedimentos regenerativos. A regeneração é feita através de enxertos ósseos que estabelecem um arcabouço para a reparação tecidual, aumentando os tecidos ósseos nos defeitos resultantes de trauma ou cirurgias, preenchendo os alvéolos após extração para preservar a altura e espessura do rebordo alveolar e aumentando e/ou reconstruindo o rebordo alveolar. Estes procedimentos são realizados através da utilização de enxertos autógenos, alógenos, aloplásticos ou xenogênicos, tendo cada um suas características e indicações. Com o desenvolvimento dos implantes osseointegrados, viu-se a necessidade de manter uma boa quantidade e qualidade óssea. Este projeto tem como objetivo avaliar a resistência a tração e módulo de elasticidade do osso mineralizado e desmineralizado de calvária de ratos, a fim de determinar padrões iniciais (máximos e mínimos) para comparações com possíveis biomateriais de preenchimento de osteoindução e osteocondução. Foram utilizados 24 animais divididos em 2 grupos. O grupo 1 $(n=12)$ : módulo de elasticidade sendo que utilizaremos as duas parietais do animal, possibilitando 24 espécimes, subdividido em mineralizado $(n=12)$ e desmineralizado $(n=12)$. O grupo $2(n=12)$ : microtração, sendo que 12 hemicalvária foram utilizado para o sub-grupo desmineralizado e as outras 12 hemicalvária para o sub-grupo mineralizado. Após a morte dos animais, os espécimes serão coletados e tratados de acordo com o subgrupo (mineralizado e desmineralizado). Os testes foram realizados numa máquina de teste universal (Vitrodyme, V1000). As médias de resistência a tração do mineralizado foi 129,814 $\pm 34,921 \mathrm{MPa}$ e o desmineralizado foi $18,547 \pm 3,682 \mathrm{MPa}$. Para o módulo de elasticidade obtivemos os valores de 1377,792 \pm 208,331 MPa para o grupo mineralizado e 49,669 $\pm 11,204 \mathrm{MPa}$ para o grupo desmineralizado, ao compararmos o módulo de elasticidade e resistência a tração entre os subgrupo desmineralizado e mineralizado observa-se uma diferença estatisticamente significante para o grupo mineralizado $(p<0,001)$. Conclui-se que 0 teste de microtração pode ser utilizado para avaliar as propriedades mecânicas nesse modelo experimental biológico.

Palavras-chaves: Implantes dentários. Osso. Materiais biocompatíveis. 


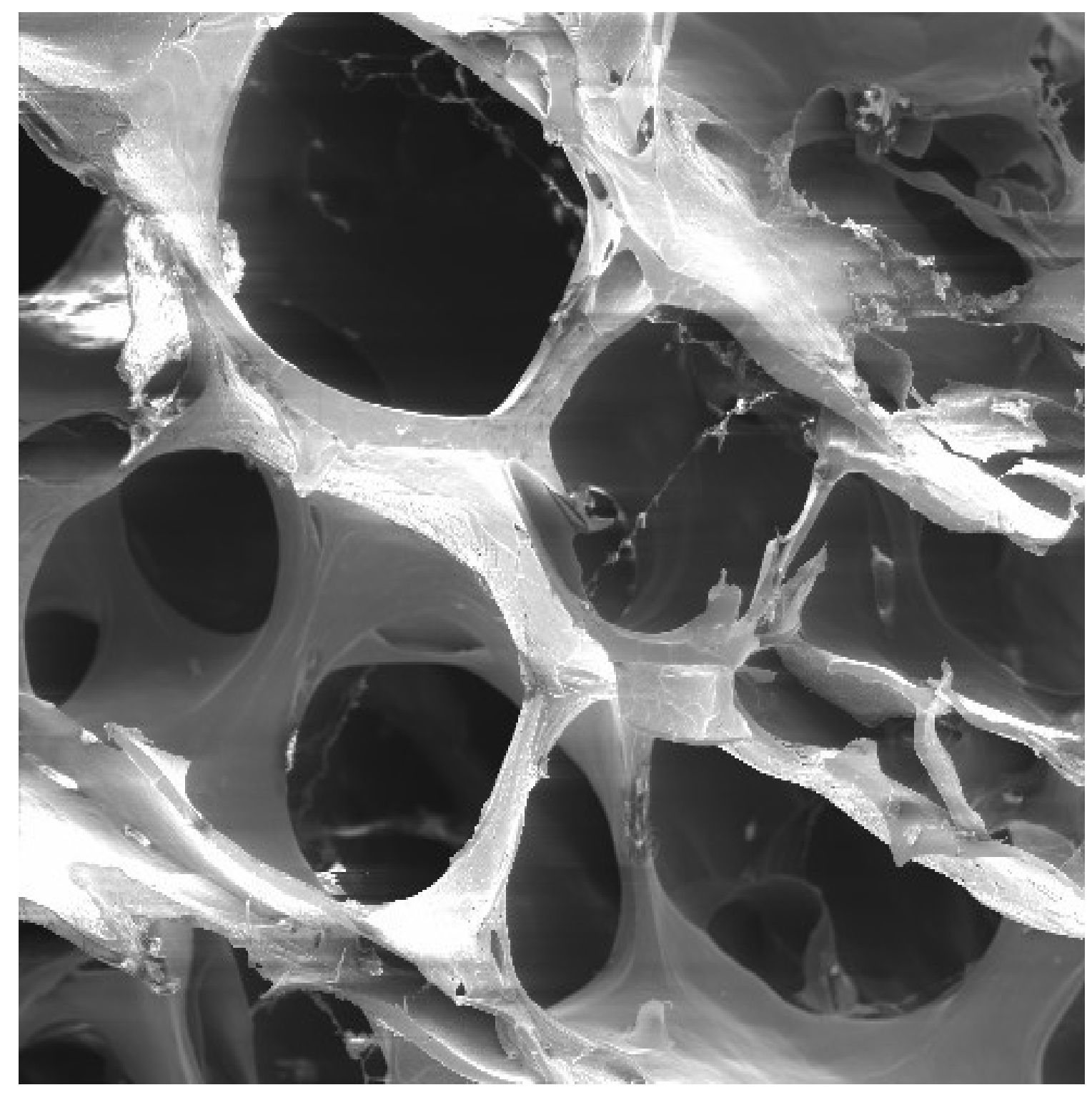

\section{1 - INTRODUÇÃO}

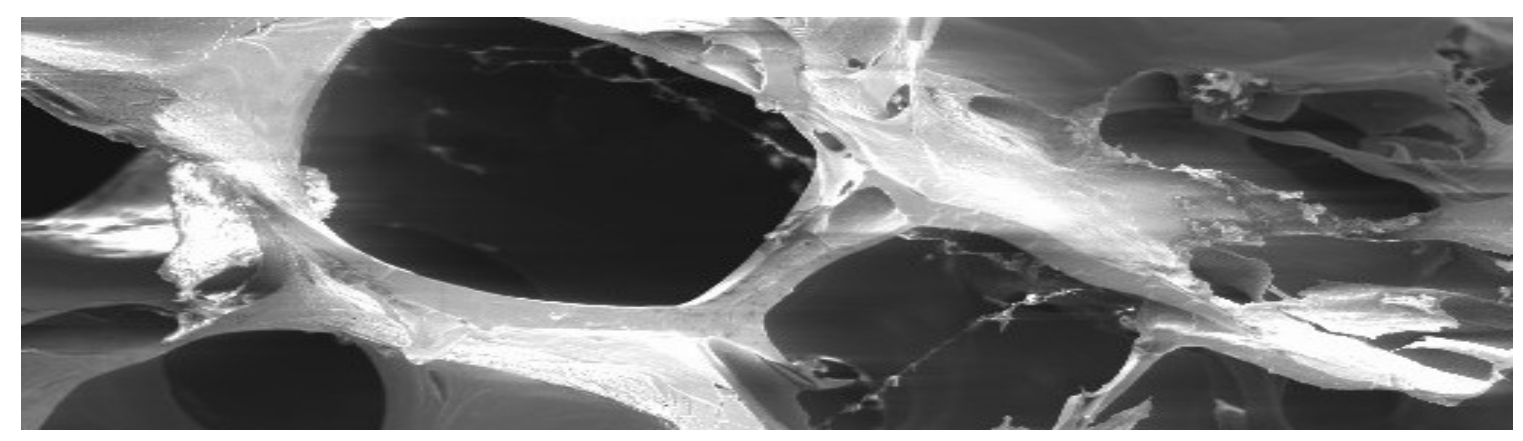




\section{INTRODUÇÃO}

Quando se tem a perda do elemento dentário, seja por cárie dentária, doença periodontal, traumas, trepanações, lesões endodônticas, entre outras, ocorre o desencadeamento de um processo fisiológico de reabsorção do tecido ósseo nesta área, que pode ser em altura ou espessura, denominada de reabsorção do rebordo alveolar (HOWELL et al. ${ }^{53}$, 1997, JAHANGIRI et al. $^{57}, 1998$, SCHEER; BOYNE $\left.{ }^{90}, 1987\right)$.

Após a extração dentária há uma série de eventos fisiológicos, levando a uma resposta inflamatória, juntamente com o preenchimento do alvéolo pelo coágulo sanguíneo. Os tecidos epiteliais iniciam sua proliferação e migração na primeira semana. Após duas semanas, observa-se a presença de tecido ósseo na porção mais profunda do alvéolo, que será preenchido lentamente por um novo tecido ósseo num período de 6 meses. Em média, a maxila perde cerca de 2 a $4 \mathrm{~mm}$ de osso no primeiro ano após a exodontia e $0,1 \mathrm{~mm}$ por ano no anos subseqüentes. Na mandíbula, a perda óssea no primeiro ano é de 4 a $6 \mathrm{~mm}$ e a média anual passa a ser de 0,4mm. Esta remodelação óssea afeta o funcionamento de qualquer prótese que se apóie sobre o rebordo residual, dificultando a reabilitação protética desses pacientes, seja através de próteses totais, parciais removíveis ou próteses sobre implantes (fixas ou removíveis) (AMLER ${ }^{4}$, 1969, JAHANGIRI et al. ${ }^{57}, 1998$, SIMPSON $\left.^{93}, 1969\right)$.

Devido a esta dificuldade, a literatura tem demonstrado que a utilização de biomateriais no preenchimento destes alvéolos após a exodontia pode contribuir na manutenção tanto da altura como em espessura (HOWELL et al. ${ }^{53}$, 1997) e com o avanço da tecnologia médica e odontológica observa-se um crescimento dos biomateriais no intuito de se buscar uma melhoria em relação à reabsorção óssea causada pela extração dentária.

Os biomaterias encontrados no mercado são inúmeros, com indicações de uso de acordo com seu mecanismo de ação e origem.

O mecanismo de ação desses enxertos ósseos ocorre de quatro maneiras: osteogênese, osteoindução, osteopromoção e osteocondução (FRAME $^{40}$, 1987, LANE ${ }^{61}$, 1995, MELLONIG; PREWETT; MOYER ${ }^{68}$, 1992, PINTO et al. ${ }^{78}$, 2000). A osteogênese é a formação e desenvolvimento do osso 
a partir de células ósseas presentes no material utilizado, o osso autógeno. Desta forma o enxerto osteogênico é derivado de tecido ósseo de um local diferente do sítio receptor. Células osteogênicas podem favorecer a formação óssea em tecidos moles ou ativarem rapidamente o crescimento ósseo em sítios com presença do tecido ósseo, uma vez que agregam as propriedades de ostegênese, osteoindução e osteocondução, definidas a seguir:

- Osteoindução é a ação ou processo de estímulo à osteogênese. Enxertos osteoindutores são utilizados como intensificadores da regeneração óssea, e o osso pode crescer ou estender-se dentro de áreas onde normalmente não se encontra tal tecido. O potencial de osteoindução é disparado por proteínas morfogenéticas ósseas (BMPs) isoladas da matriz óssea (WOZNEY $\left.{ }^{112}, 1995\right)$ ou pela própria matriz óssea (URIST $\left.{ }^{104}, 1965\right)$.

- Osteocondução é dependente de uma matriz física ou um arcabouço capaz de guiar as células envolvidas no processo de reparo, promovendo a angiogênese e a deposição de novo osso. Estes materiais, entretanto, são incapazes de induzir à formação óssea ectópica como ocorre com os enxertos osteoindutores.

Dependendo da origem, os materiais para enxerto ósseo podem ser classificados como: autógeno, alógeno e aloplástico.

O enxerto autógeno é, ainda, a referência ("gold standard") devido a vantagens biológicas, por possuir alto poder osteogênico e preencher adequadamente os requisitos referentes à estrutura de arcabouço, essencial para a regeneração óssea (BECKER; BECKER; CAFFESSE ${ }^{11}$, 1994). O osso autógeno pode ser obtido da crista ilíaca ou sítios intraorais (sínfise mandibular, tuberosidade maxilar, ramo e exostoses) (KOOLE; BOSKER; VAN DER DUSSEN $^{59}$, 1989, MISCH; DIETSH ${ }^{71}$, 1993). Porém, uma série de inconvenientes como um maior período de convalescença, morbidade e susceptibilidade a infecções no sítio doador e a reabsorção progressiva e constante do enxerto, estimulou a busca de novos materiais para substituir este tipo de enxerto (GOSAIN $\left.{ }^{46}, 1997\right)$.

O aloenxerto é obtido de outro indivíduo da mesma espécie, apresentando-se em várias formas para utilização de acordo com o processamento laboratorial: congelados, liofilizados, desmineralizados 
juntamente com a liofilização ou irradiados. Esses materiais potencialmente podem transmitir o HIV, mas estudos têm demonstrado, que por meio do congelamento ou utilização de agentes anti-viróticos e a desmineralização, ocorre a inativação do agente patogênico (BUCK et al. ${ }^{20}, 1990$, DIES et al. ${ }^{34}$, 1996), e a possibilidade de transmissão, atualmente, é de aproximadamente 1:1.600.000 (BUCK; MALININ; BROWN ${ }^{19}$, 1989).

Os derivados inorgânicos como o fosfato tricálcico e a hidroxiapatita (enxertos autoplásticos) receberam grande atenção como materiais de preenchimento, espaçadores e substitutos para os enxertos ósseos, principalmente devido à sua biocompatibilidade, bioatividade e características de osteocondução em relação ao tecido hospedeiro (BURSTEIN et al. ${ }^{25}$, 1997, DE GROOT ${ }^{32}$, 1980). Porém, foi relatado que a hidroxiapatita sintética (biomaterial aloplástico) possui microestrutura e tamanho do cristal, diferente do osso natural, podendo produzir resposta biológica indesejada (STEPHAN et al. $\left.{ }^{95}, 1999\right)$, pois a falta de padronização do tamanho da partícula interfere no processo de reparo ósseo.

$\mathrm{Na}$ busca por alternativas à realização do segundo leito cirúrgico (enxerto autógeno) ou aos riscos de contaminação e custos com exames laboratoriais (enxerto alógeno), o enxerto xenogênico (obtido de outra espécie) vem apresentando resultados promissores. Alicerçado na fácil aquisição, baixo custo do osso bovino e no processamento mecânico e químico adequados, diversas empresas vêm produzindo biomateriais de origem bovina, utilizandoos como substituto ósseo (Gen-Ox ${ }^{\circledR}$, Baumer S.A., Mogi Mirim, Brasil; Keil Bone $^{\mathrm{TM}}$, Braun Milsungen, Milsungen, Alemanha; Bio-Oss ${ }^{\mathrm{TM}}$, Geistlich Pharma, Wolhusen, Suíça; e Surgibone ${ }^{\mathrm{TM}}$, Unilab Surgibone, Mississauga, Ontário, Canadá) (ZHAO et al. $\left.{ }^{113}, 1999\right)$.

Todos estes biomateriais sofrem diversos processos de avaliações laboratoriais, experimentos em animais e humanos para serem integrados ao meio mercadológico. Dentre os processos laboratoriais, temos avaliação de cultura de células, citotoxicidade, análises imunológicos sendo esses processos muitas vezes distantes do meio odontológico, pois há necessidade de laboratórios bem equipados e equipe multidisciplinar (biólogos, 
farmacêuticos, engenheiros, cirurgiões-dentistas, técnicos de laboratório, dentre outros).

Por outro lado, observamos uma grande participação da área odontológica nos procedimentos experimentais clínicos e em animais, muitas vezes para não depender de profissionais de outras áreas. Dentre os experimentos em animais temos diversos modelos (ratos, macacos, cães, porcos, cobaias, coelhos), que podem avaliar esses biomateriais de várias formas biológicas (biocompatibilidade, tempo de reparo ósseo, resposta imunológica, resposta inflamatória, contagem e tipo celular).

Um dos modelos experimentais para avaliação do reparo de áreas enxertadas é a calvária de ratos, cujo modelo consta da realização de defeitos na calvária do animal e preenchida com diversos biomateriais, avaliando-se assim sua biocompatibilidade, tempo de reparo, tipo celular, qualidade e quantidade de tecido ósseo formado, dentre outros.

O defeito na calvária de ratos pode ser classificado em 2 tipos: críticos (maiores que $6 \mathrm{~mm}$ de diâmetro) ou não críticos (menores que $6 \mathrm{~mm}$ de diâmetro) (AABOE; PINHOLT; HJORTING-HANSEN ${ }^{1}, 1995$, AHN et al. ${ }^{2}, 2003$, BOSCH; MELSEN; VARGERVIK ${ }^{16}, 1998$, FOWLER et al. ${ }^{39}, 2002$, FRANCIS et al. $^{41}$, 2003, GLOWACKI; ALTOBELLI; MULLIKEN ${ }^{45}$, 1981, HAN et al. ${ }^{48}$, 2005, HONG et al. ${ }^{51}, 2006$, HYUN et al. ${ }^{55}$, 2005, JUNG et al. ${ }^{58}, 2006$, LEE et al. ${ }^{62}$, 2003, MATZENBACHER et al. ${ }^{67}$, 2003, PANG et al. $^{76}, 2005$, POEHLING et al. $^{79}$, 2006, PRYOR et al. ${ }^{80}$, 2005, PRYOR; SUSIN; WIKESJO ${ }^{81}$, 2006, TAMIMI et al. ${ }^{97}, 2006$, TAMURA et al. ${ }^{98}$, 2005, VERNA et al. ${ }^{110}$, 2002). A realização de um defeito crítico está indicado para casos em que se verifica a necessidade do biomaterial possuir capacidade de indução e/ou condução à uma formação óssea em casos onde não haja fechamento natural dessa área, ou seja, o biomaterial teria capacidade induzir e/ou conduzir uma formação óssea além da capacidade fisiológica do organismo em se reparar. Este tipo de experimento é classificado em grupos de diferentes períodos de sacrifício para possibilitar acompanhamento histológico e radiográfico do reparo ósseo, podendo-se assim quantificar o tempo de reparo do defeito.

No caso de defeitos não críticos em calvária de ratos, o objetivo é a avaliação da qualidade e quantidade de tecido formado pelo biomaterial, seja pelo seu papel osteoindutor, ostocondutor ou osteogênico, pois neste modelo 
experimental temos a certeza do fechamento do defeito criado, avaliando-se somente o tipo celular, quantidade e qualidade óssea.

Existem outros fatores importantes na avaliação desses biomateriais como as suas propriedades mecânicas (resistência, módulo de elasticidade, tenacidade, plasticidade, etc). A literatura mostra-se vasta quando se quer a avaliação do tecido ósseo na área ortopédica, principalmente nos casos de ossos longos, como por exemplo, fêmures ou tíbias humanas ou bovinas, e os testes realizados em geral são de tração ou compressão de ossos longos, nanoedentação, mensurações ultrasônicas e microtração.

Em odontologia não se tem avaliação dos tecidos neoformados quanto a sua resistência, embora seja de grande importância, principalmente quando se relaciona à implantodontia, pois quando ocorre a perda do elemento dentário há a previsibilidade da colocação de implantes osseointegrados nesta área com a utilização dos biomateriais para a preservação do tecido ósseo do alvéolo, sendo grande o estudo na literatura para a avaliação histológica desta área, tanto em experimentos animais como em humanos. Observa-se a ausência da avaliação das propriedades mecânicas dessas áreas enxertadas, seja em experimentos animais ou em humanos.

Constada a falta de estudo da resistência óssea, nosso trabalho tem como objetivo unir duas metodologias consolidadas pela literatura (avaliação de reparo ósseo em calvária de ratos e teste de resistência pela técnica de microtração) para a avaliação da resistência e módulo de elasticidade do osso mineralizado e desmineralizado da calvária de ratos através do teste de microtração, possibilitando assim criar padrões (máximo e mínimo) de resistência e módulo de elasticidade para futuras comparações de áreas reparadas com diversos biomateriais em calvária de ratos. 


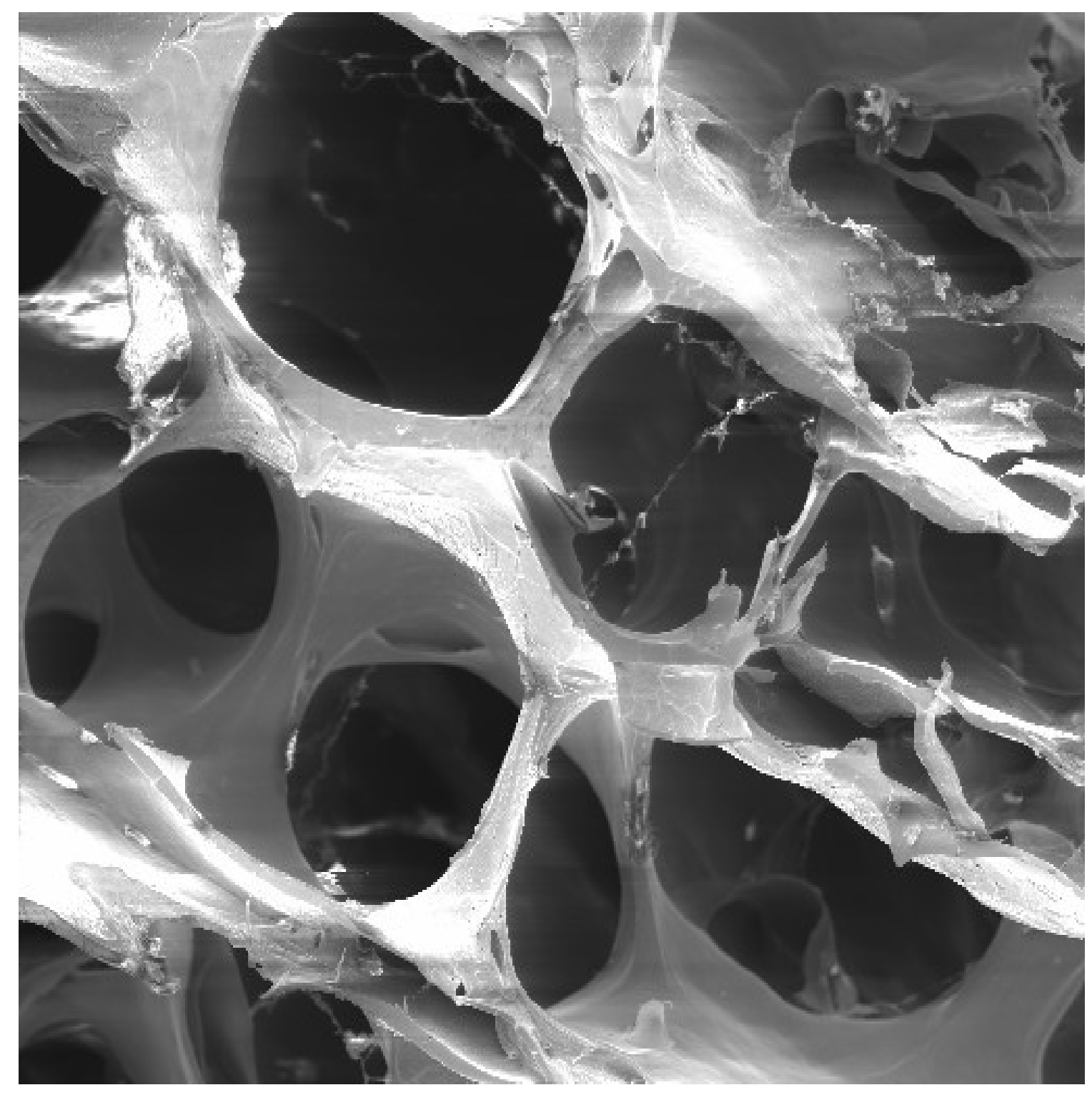

\section{2 - REVISÃO DE LITERATURA}

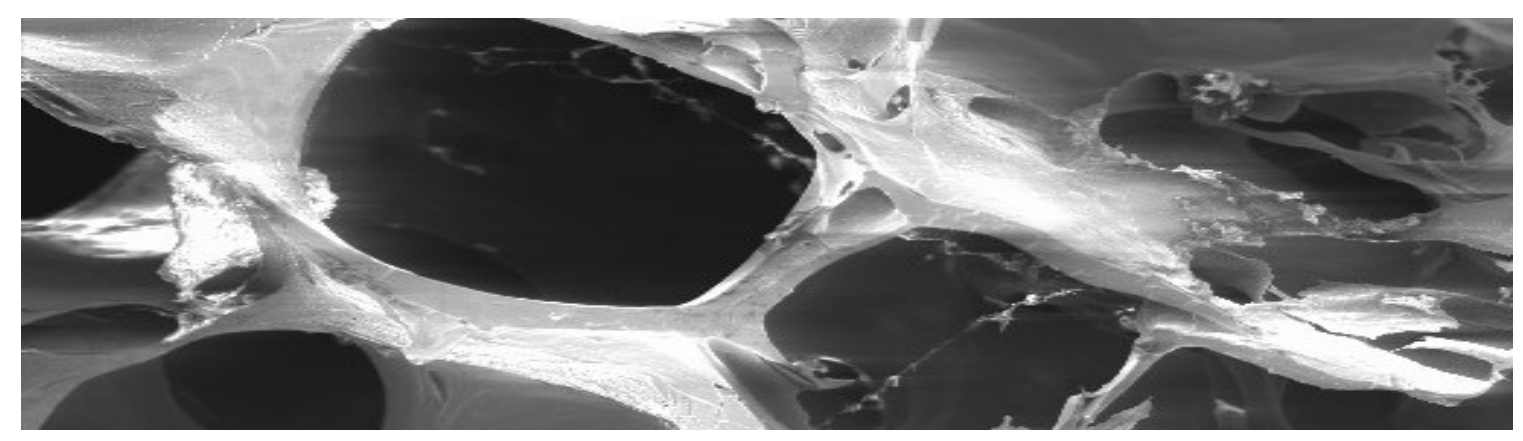




\section{REVISÃO DE LITERATURA}

\subsection{TECIDO ÓSSEO}

O osso é uma importante reserva mineral que tem como função o suporte, proteção e a locomoção do corpo humano. Seu metabolismo é controlado sistemicamente por meio de hormônios e por influência direta das forças mecânicas e piezoelétricas, capazes de reparar defeitos locais com tecido regenerado, restaurando seu aspecto sem deixar cicatriz. O modelo reparador é considerado uma recapitulação da osteogênese embriológica e do crescimento. Este tecido conjuntivo especial é constituído por cerca de $65 \%$ de matriz mineral (hidroxiapatita), 25\% de matriz orgânica (proteína) e 10\% de água ( $\left(\mathrm{LANE}^{60}, 1979\right.$ ), sendo que $90 \%$ da fase orgânica é constituída por colágeno, proteoglicanos de pequeno peso molecular e proteínas não colágenas. Seu arranjo macroscópico é caracterizado por uma densa camada externa de osso compacto que envolve um interstício medular.

Histologicamente é possível identificar três tipos de arranjos morfológicos: circunferencial, concêntrico e intersticial. O circunferencial é aquele que cobre o osso adulto, o concêntrico é a massa de osso compacto e sua forma metabólica básica chamada de ósteon. $O$ arranjo intersticial é encarregado de ocupar os espaços entre os ósteons.

As células que compõem o tecido ósseo são quatro:

- Osteoprogenitoras - encontrada na medula óssea, periósteo e na cavidade medular. Possui capacidade de se diferenciar quando é estimulada.

- Osteoblastos - são oriundas das células osteoprogenitoras, sua função é de síntese protéica e formação do tecido ósseo.

- Osteócitos - células que se caracterizam por serem osteoblastos aprisionados na matriz óssea, sendo mediadoras de uma importante função dentro do tecido onde recebem e transmitem sinais elétricos atraindo, através 
destes, ou um osteoblasto ou um osteoclasto dando, assim, início ao processo de remodelagem.

- Osteoclastos - derivado de monócitos circundantes no sangue, é responsável pela reabsorção do tecido ósseo.

\subsection{ENXERTO ÓSSEO}

Os enxertos podem ser classificados quanto sua origem e quanto ao seu mecanismo de ação. Em relação a sua origem os enxertos ósseos podem ser: autógeno, alógeno, xenógeno e aloplástico.

O autógeno é removido do próprio paciente, de regiões doadoras extrabucais (ilíaco, calota cranaina, clavícula) ou intrabucais (região do mento, região da linha obliqua externa, tuberosidade), de acordo com a quantidade necessária. A vantagem deste enxerto é a presença de células osteoprogenitoras e osteoblastos viáveis junto a matrizes orgânica e inorgânica (HUNT; JOVANOVIC ${ }^{54}$, 1999). Outra vantagem é ausência de rejeição, mas por outro lado o risco de reabsorção é alto, podendo acontecer antes mesmo de se completar a osteogênese (BURG; PORTER; KELLAM ${ }^{22}, 2000$ ). Dentre as desvantagens do enxerto autógeno estão: existência do segundo sítio cirúrgico, morbidade pós-operatória, volume ósseo limitado e a possibilidade de seqüelas (OREFFO; TRIFFITT ${ }^{75}$, 1999).

O alógeno é adquirido a partir de osso humano, através de bancos de ossos humanos, e se apresenta em duas formas: enxerto alógeno de osso liofilizado (FDBA) e enxerto alógeno de osso liofilizado desmineralizado (DFDBA). Este tipo de enxerto se caracteriza por estimular resposta imune no receptor.

O xenógeno é oriundo de outras espécies, principalmente de origem bovina. Exigem processamento adequado para eliminar o potencial antigênico, pois o grande problema destes materiais está na possibilidade da transmissão do príon, proteína causadora da encefalopatia espongioforme bovina (doença da "vaca louca"). WENZ; OESCH; HORST ${ }^{111}$, 2001, comentaram que este 
risco diminui à medida que o osso passa por um tratamento acima de $300^{\circ} \mathrm{C}$ ou com álcalis, seguindo de neutralização, removendo-se praticamente toda possibilidade da presença de príon porventura existente na amostra, assegurando-se assim a proteção contra a transmissão. O Brasil tem ainda uma posição invejável neste campo, por ter seu rebanho livre da doença.

O aloplástico é de origem sintética, apresentado em texturas, tamanhos e formas diversas. O desenvolvimento destes materiais é cada vez maior, pois são sabidas as dificuldades encontradas em outros tipos de enxerto. Entre suas vantagens, estão o controle dos riscos biológicos, suas propriedades físico-químicas e seu custo.

Os mecanismos de ação do enxerto são classificados em três categorias distintas, porém um mesmo tipo de enxerto pode possuir mais de um mecanismo de ação, e ainda, os materiais de origens diferentes podem assumir o mesmo mecanismo de ação requerido no tipo de tratamento desejado: osteoindução, osteocondução e osteopromoção.

A osteoindução é o mecanismo pelo qual o tecido é estimulado a formar elementos que permitem a osteogênese, principalmente à diferenciação de células mesenquimais em osteoblastos. O estímulo pode partir do próprio enxerto em um ambiente favorável para a osteogênese. Em condições ideais a osteoindução estimula a osteocondução, criando então uma aceleração do processo em relação aos demais materiais não viáveis ou não biológicos (BURCHARDT ${ }^{21}$, 1983).

Osteocondução é dependente de uma matriz física ou um arcabouço capaz de guiar as células envolvidas no processo de reparo, promovendo a angiogênese e a deposição de novo osso. Estes materiais, entretanto, são incapazes de induzir a formação óssea ectópica como ocorre com os enxertos osteoindutores.

A osteopromoção é a capacidade de um material proporcionar a proliferação tecidual sem que haja interferência de fatores externos ou internos 
para tal evento, promovendo uma proliferação óssea (Regeneração Óssea Guiada - ROG) ou tecidual/conjuntivo (Regeneração Tecidual Guiada - RTG).

A osteogênese define-se como a transferência de células viáveis do enxerto para o leito receptor. Aqui existem controvérsias sobre o início do processo de cicatrização, pois existe a hipótese de que as células ósseas do espaço criado pelo enxerto tenham origem no hospedeiro, estimuladas pelo enxerto. De qualquer maneira, ambas as origens devem contribuir para população celular (MILLER et al. ${ }^{70}, 1991$ ). Após a instalação do enxerto iniciarse-á a reparação óssea pela liberação dos fatores de crescimento no enxerto e pela degranulação das plaquetas.

Os fatores liberados são os Fator de Crescimento Transformante (TGF-ß), o Fator de Crescimento de Fibroblasto (FGF), e o Fator de Crescimento Similar a Insulina (IGF) que são responsáveis pela migração de células endoteliais, e pela proliferação e formação de capilares além de outros eventos celulares. O Fatores de crescimento derivados das plaquetas (PDGF) estimula a mitogênese e inicia a angiogênese do complexo capilar. Suas ações nos osteoblastos são de mitose e de quimiotaxia (GAMAL et al. ${ }^{43}$, 1998, HAASE et al. ${ }^{47}$, 1998, MATSUDA et al. ${ }^{66}$, 1992). Os TGF-ßs são fatores de crescimento e de transformação. São cinco os membros desta família (B1 a B5), destes apenas o $B 1$ e o $B 2$ estão ligados à regeneração óssea. Suas funções mais importantes são a quimiotaxia e a mitogênese dos osteoblastos. O IGF atua nos osteoblastos do endósteo para limitar o enxerto ósseo. Uma resposta coordenada de várias células é desencadeada nos tecidos biológicos. Estas células são responsáveis pela defesa humoral que neutralizam e eliminam moléculas estranhas, trocando sinais para ativar os processos de sobrevivência do organismo.

A resposta humoral é decorrência de uma série de ações que freqüentemente ocorre e pode ser classificada em diversas fases. A primeira fase é a de inflamação, caracterizada por uma série de atividades celulares como crescimento de capilares sanguíneos, multiplicação e a diferenciação das células mesenquimais indiferenciadas do canal medular em osteoblastos. Estes irão secretar TGF-ß e IGF na matriz óssea. O PDGF atrai os macrófagos para 
área enxertada. A partir desta etapa os processos reparativos serão mediados pelos fatores de crescimento derivados dos macrófagos (FCDM). Sendo que a resposta autócrina é mantida por células oriundas do canal medular que continuam a secretar TGF-ß e IGF.

$\mathrm{Na} 2^{\text {a }}$ fase os fatores de crescimento contribuem no processo de regeneração, principalmente na mitogênese das células do canal medular e angiogênese capilar. Caracteriza-se pela consolidação clínica do enxerto. Na fase final o enxerto já é vascularizado e a regeneração óssea está em fase final. O estágio chamado de remodelação é caracterizado pela liberação de proteína morfogenética óssea (BMP) e IGF e proteínas ácido-insolúveis. A arquitetura óssea já é madura havendo a presença de sistemas haversianos, endósteo e periósteo, portanto considerada auto sustentada.

\subsection{UTILIZAÇÃO DE BIOMATERIAIS EM ALVÉOLOS}

Em 1974, OKAMOTO et al. ${ }^{74}$ desenvolveram uma linha de pesquisa sobre reparo alveolar frente a vários fatores, sejam intrínsecos ou extrínsecos. Relataram uma análise do material BOPLANT, osso bovino desprovido das frações orgânicas, em alvéolos de ratos, para avaliar o comportamento do processo de reparo em feridas de extração dental. Foram utilizados 24 ratos divididos em 6 grupos mortos após 1, 3, 6, 9, 15 e 21 dias após o enxerto. 0 material foi colocado em alvéolos dos incisivos superiores, sendo compactado no interior do coágulo em formação, preenchendo parcialmente o alvéolo. Após os sacrifícios, as biópsias foram processadas para confeccionar lâminas coradas com hematoxilina e eosina. Com base nos resultados histológicos, concluíram que o reparo alveolar é retardado pela presença do material, que provocou intensa reação inflamatória nos estágios iniciais, não estimulando a osteogênese; porém na reconstrução de cristas alveolares ou para perda de lesões periodontais o material mostrou excelentes resultados.

Em 1987, SCHEER; BOYNE ${ }^{90}$ realizaram uma revisão de literatura sobre alguns biomateriais para manutenção de osso do rebordo alveolar, enfatizando o uso da hidroxiapatita (HA) sintética e osso bovino inorgânico. A HA sintética é um material compatível e osteofílico, mas não osteogênico, ou 
seja, ele não promove o crescimento ósseo, mas possui a função de um mantenedor de espaço ou um arcabouço para a proliferação celular e formação óssea. O osso bovino inorgânico demonstrou ser biocompatível e com reabsorção mais lenta que a HA sintética, tendo o rebordo alveolar enxertado com osso bovino inorgânico apresentando melhor conformidade e com menores ângulos do que o rebordo que recebeu a HA sintética.

BONACHELA et al. ${ }^{15}$, 1992, relataram um caso clinico, em que na extração dos dentes $31,32,41,42,43,44,45$ foi usada a HA sintética microgranular (Biohidroxi - Inodon), em seus respectivos alvéolos para auxiliar na manutenção do rebordo alveolar. Um protocolo cirúrgico foi realizado para propiciar o menor dano possível aos tecidos adjacentes que levaria a um melhor reparo da ferida cirúrgica. Após as exodontias, o biomaterial foi inserido no alvéolo, o tecido gengival foi suturado buscando uma boa coaptação das margens do retalho. A função mastigatória do paciente foi reestabelecida com a instalação de uma prótese total imediata (PTI), seguida de avaliação radiográfica e clínica. Após 7 dias, foram notadas ulcerações provocadas pela $\mathrm{PTI}$, mas a área da intervenção cirúrgica seguia o processo normal de reparação. Aos 3 meses a mucosa estava firme à palpação e com uma coloração normal, sem ulcerações. A análise radiográfica evidenciou 0 aumento da radiopacidade na região apical dos alvéolos e também na manutenção do nível ósseo original.

BECKER et al. ${ }^{13}, 1992$, compararam a formação de osso ao redor de implantes colocados em alvéolos de cães imediatamente após exodontia, alvéolos nos quais foram realizados deiscências nas paredes vestibulares, com uso de brocas. Os grupos foram divididos de seguinte forma; 1) Implante + Membrana de Politetrafluoretileno expandida (PTFE-e); 2) Implante + PTFE-e + osso alógeno cortical desmineralizado liofilizado; 3) Implante + PTFE-e + fatores de crescimento de plaqueta + fatores de crescimento insulinodependente 1. Após 18 meses os animais foram sacrificados e submetidos a processos laboratorias histológicos para futura análise histológica. Após a análise dos resultados no grupo 2 o nível ósseo manteve-se inalterado. No grupo 1 e 3 foram encontrados resultados diferentes, ocorrendo crescimento 
ósseo ao redor do implante. Histologicamente, o grupo 3 apresentou maior densidade óssea comparada aos outros grupos.

BECKER; BECKER; CAFFESSE ${ }^{11}, 1994$, avaliou a capacidade de formação óssea do osso desmineralizado liofilizado colocado em alvéolos humanos após exodontia. Os pacientes deveriam apresentar 2 sítios com dentes peridontalmente condenados, sendo que sete pares de sítio foram enxertados com osso desmineralizado liofilizado ou osso autógeno. Os sítios foram reabertos entre 3 e 13 meses para a obtenção das biópsias e colocação de implantes. As biópsias foram coletadas da seguinte forma: 1 biópsia após 3 meses; 2 após 4 meses da cirurgia; 2 após 7 meses da cirurgia; 1 após 8 meses da cirurgia e 1 após 13 meses da cirurgia. Nos sítios que receberam osso desmineralizado liofilizado constatou-se a presença de partículas do enxerto sem nenhuma evidência de formação óssea em sua superfície e nenhuma evidência de reabsorção por osteoblastos de partículas ósseas. Já nas biópsias de 6 sítios autógenos observaram-se canais vasculares com osso medular e lamelar, formação óssea secundária e, sinais de reabsorção. Alguns espécimes apresentavam esquírolas ósseas não vitais que estavam sendo reabsorvidas por osteoclastos.

DIES et al. ${ }^{34}, 1996$, analisaram 12 casos clínicos submetidos à regeneração tecidual guiada (RTG) com ou sem biomaterial (Bio-Oss ou DFDBA) sob uma membrana de PTEF-e. Histologicamente observou-se que houve formação óssea em todos os casos, mas com variações individuais na quantidade de osso formado, confirmando os dados obtidos radiograficamente e clinicamente. Nos sítios tratados apenas com membrana, havia osso lamelar com grande espaço medular nos períodos de 6 meses, enquanto que aos 9 meses observava-se boa densidade óssea. Nos sítios com membrana e biomaterial observou-se tecido ósseo mineralizado e com grande quantidade de xenoenxerto após 6 meses, demonstrando o maior tempo necessário para a regeneração óssea.

BECKER et al. ${ }^{12}$, 1998, realizaram um levantamento de casos clínicos de 7 diferentes centros clínicos e observaram clinicamente 15 pacientes e o aspecto microscópico de 21 biópsias. Os enxertos de osso 
autógeno foram da região intra-oral e aplicados a 6 sítios, osso desmineralizado liofilizado a 7 sítios, osso mineralizado liofilizado a 7 sítios ou a combinação de osso autógeno com osso desmineralizado liofilizado e membrana aplicada a 1 sítio. Estes sítios foram alvéolos ou em recobrimento de implantes. Foi determinado um escore de 0-4 para avaliar a presença de restos de materiais implantados, vasos sanguíneos, ilhas de cartilagem, osteoblastos e formação de novo osso. Os resultados demonstraram que o osso desmineralizado liofilizado e o osso mineralizado liofilizado proporcionaram valores inferiores a 1 devido à retenção de partículas de enxerto não vital dentro de tecido fibroso conjuntivo. Nas biópsias adjacentes o leito hospedeiro demonstrou incorporação de aloenxerto (osteocondução), concluindo que o enxerto autógeno e o aloenxerto podem ser carreadores biológicos, mas aparentemente não contribuíram para osteoindução.

HOWELL et al. ${ }^{53}$, 1997, avaliaram a BMP-2 recombinante humana (rhBMP-2) associada a uma esponja de colágeno absorvível e utilizadas para preservação do rebordo alveolar depois da extração dentária ou aumento ósseo de defeitos localizados. Os autores avaliaram a segurança e a facilidade técnica da implantação da rhBMP-2. Foram monitorados 12 pacientes, sendo 6 para preservação de rebordo e 6 para aumento do rebordo alveolar. A facilidade da técnica foi avaliada pela coleta de informação relatada pelos cirurgiões quanto as propriedades do manejo da rhBMP-2. Observaram que a manipulação foi fácil e a adaptação nos rebordos e alvéolos adequadas. A análise clínica evidenciou que a rhBMP-2 foi bem tolerada sistêmica (por exemplo, não houve nenhuma resposta alérgica ou imunológica) e localmente (edema, rejeição do enxerto). Todos os sítios demonstraram firmeza e integridade à palpação na $4^{\mathrm{a}}$ semana, mostrando porém uma perda de volume em algumas áreas entre $4^{\mathrm{a}}$ e $8^{\mathrm{a}}$ semana.

PERRI DE CARVALHO; OKAMOTO; GARCIA JR. ${ }^{77}, 1998$, realizaram um estudo laboratorial onde se utilizou a hidroxiapatita policristalina porosa não reabsorvível (Osteosynt, Einco BHZ, Brasil) associada ou não com uma membrana de teflon (Regetec, Brasil) em alvéolo de ratos, com objetivo de se comparar histologicamente a evolução do processo de reparo em feridas de 
extração dental com alveolectomia parcial. Verificou-se que o colágeno não preencheu uma de suas finalidades, que seria de auxiliar na fixação e manutenção da hidroxiapatita na área implantada. $O$ tempo de reparo foi mais lento no grupo em que se empregou a membrana.

Em 1998, BECKER et al. ${ }^{12}$ realizaram um estudo comparativo entre osso bovino inorgânico ( $n=5$ sítios), osso desmineralizado liofilizado ( $n=3$ sítios), osso autógeno ( $\mathrm{n}=3$ sítios) ou BMP humana (hBMP) associada osteocalcina/osteonectina ( $\mathrm{n}=2$ sítios), em 3 pacientes que receberam 6 micro parafusos fixados nos alvéolos implantados com o osso bovino (3 sítios), osso humano liofilizado desmineralizado (DFDBA) (2 sítios) ou osso autógeno intraoral (1 sítio). Nas biópsias do grupo que recebeu o osso bovino revelou-se partículas do enxerto ao redor do tecido conjuntivo. Foram observados também osso do hospedeiro em contato com partículas de osso bovino. No grupo com DFDBA foi notada a presença de partículas do enxerto entrelaçadas com tecido conjuntivo denso. Em biópsias de hBMP exibiram combinação de osso medular e lamelar. Com os micros parafusos e osso bovino houve uma interface de tecido conjuntivo entre o parafuso e o tecido ósseo circundante. Os parafusos associados ao DFDBA estavam circundados com tecido conjuntivo e com partículas de osso envolvendo o tecido fibroso. Os parafusos associado ao osso autógeno estava primariamente circundada por osso vital e com interface de tecido conjuntivo. Observaram que nos alvéolos que receberam somente os enxertos de osso bovino e DFDBA havia resquícios de materiais, enquanto que em alveolos com hBMP, já se observava formação de osso lamelar e medular.

Em 1998, LEKOVIC et al. ${ }^{63}$ utilizaram membranas bioabsorvíveis feitas de ácido polilático e poliglicólico para melhorar a preservação de rebordo alveolar em 16 pacientes com indicação de exodontia de dentes anterior ou pré-molares. Foram realizadaos as exodontias, buscando-se preservar as estruturas adjacentes, e em seguida as membranas foram colocadas seguindose a técnica de RTG e fixadas com pinos de titânio. A análise clínica evidenciou pequena perda em altura do rebordo alveolar nos sítios que receberam a membrana em comparação ao controle, sem membrana. 
$\mathrm{TAL}^{96}$, 1999, utilizaram o osso bovino desproteinizado e osso desmineralizado liofilizado (aloenxerto) ambos recobertos com enxerto de mucosa queratinizada obtida do palato do paciente. A sua avaliação foi baseada em parâmetros clínicos, julgando estes como: vital, o alvéolo deve estar totalmente selado com tecido conjuntivo após 2 semanas e o tecido gengival sem aspecto de necrose; parcialmente vital, quando parte do enxerto gengival tem sinal de vitalidade e outra com possível sinal de necrose e o alvéolo deve estar parcialmente preenchido de tecido conjuntivo após 2 semanas; não vital, o enxerto gengival é facilmente removido sem sinal de vitalidade e com exposição de coágulo e perda espontânea do enxerto ósseo durante as primeiras 2 semanas. Os resultados demonstraram que após 1 mês todas as áreas encontravam-se com selamento da mucosa. Os alvéolos preenchidos com osso desmineralizado liofilizado apresentaram uma porcentagem maior quando considerado vital ou parcialmente vital em relação ao osso bovino desproteinizado (86\% x 62\%).

THOMPSON $^{99}$, 1999, publicaram um artigo que demonstrou um protocolo minucioso na utilização de biomateriais em alvéolos após exodontia, relatando desde a aceitação do paciente até o controle pós-operatório. Foi utilizado vidro bioativo associado à membrana não absorvível de PTFE-e. Após 10 meses, radiograficamente, observou-se o alvéolo intacto e pronto para o restabelecimento protético final ou para a colocação de um implante osteointegrado.

GAUTHIER et al. $^{44}$, 1999, utilizaram um polímero derivado de celulose (metil-hidroxi-propil-celulose, MHPC) associado a grânulos de fosfato de cálcio bifásico implantados em alvéolos de pré-molares superiores e inferiores de cachorros. Após 3 meses da implantação foi realizada a biopsia dos alvéolos e observaram uma quantidade maior de osso formado na mandíbula, tanto do lado controle, quanto o experimental. Histologicamente, foi observada intensa mineralização constituída de osso lamelar envolta de todo grânulo do polímero. A quantidade de osso formado entre o grupo controle e o experimental não foram estatisticamente significante, sendo o controle $56,19 \%$ $\pm 12,17 \%$ e o experimental $59,15 \% \pm 8,61 \%$. 
Em 1999, SMUKLER; LANDI; SETAYESH ${ }^{94}$ utilizaram DFDBA (American Red Cross, St. Luis, MO) com membrana não reabsorvível de PTFEe (GTAM, WL Gore, Flagstaff, AZ) para avaliar a quantidade de osso formado em alvéolo após extração dentária e aumento no rebordo alveolar. Em um período entre 8 e 23 meses realizaram a biópsia e colocação de implantes na região do enxerto. Clinicamente a espessura e altura óssea em todos os casos permitiram a colocação dos implantes. Histologicamente não se observou qualquer resposta inflamatória ou encapsulamento fibroso das partículas do enxerto, encontrando porém alguns osteoclastos em volta do remanescente do DFDBA.

ARTZI; TAL; DAYAN ${ }^{8}, 2000$, avaliaram histomorfometricamente a evolução do reparo alveolar preenchido com osso bovino mineral poroso após 5 meses. O estudo foi realizado em 15 alvéolos de 15 pacientes, onde foram mensuradas as alturas iniciais dos rebordos. Após 9 meses, realizaram outra mensuração e obteve-se um valor de $82,3 \%$ de aumento do rebordo, histologicamente verificou-se que na área coronal havia uma quantidade de osso formado com abundantes células medulares, enquanto que na região apical somente um arranjo lamelar. O tecido conjuntivo diminuiu de 52,4\% para $9,5 \%$ da crista para a região apical, enquanto que para o tecido ósseo foi de $15,9 \%$ coronal para $63,9 \%$ apical.

Em um estudo in vivo utilizando poros de HA pré-incubados em solução de bifosfonato, que foram inseridos em alvéolos de cabra, para avaliar a osteocondução e o reparo alveolar, DENISSEN et al. ${ }^{33}, 2000$, observou que houve uma total integração do material acompanhado de uma boa vascularização e osteocondução para o crescimento de osso em volta e dentro da estrutura porosa.

PINTO et al. ${ }^{78}$, 2000, em relato de um caso clinico, utilizando BMPs bovina associada a hidroxiapatita absorvível $\left(\mathrm{BMP}^{\circledR}\right.$ - Dentoflex) e matriz orgânica de osso bovino liofilizado (Osseobond ${ }^{\circledR}$ - Dentoflex) em alvéolo após exodontia e recoberto com uma membrana absorvível de cortical óssea bovina liofilizada (Bioplant ${ }^{\circledR}$ - Dentoflex), verificaram que os resultados histológicos 
demonstraram osso em quantidade e qualidade satisfatória para futura instalação de implantes, sendo rico em células (osteócito) rodeadas por fibras colágenas dispostas paralelas umas a outras, boa vascularização, com atividade osteoclástica e presença de resquícios de matriz orgânica.

CAMARGO et al. ${ }^{27}, 2000$, utilizou o vidro bioativo em alvéolos após exodontia para verificar a influencia deste no processo de reparo alveolar. Após a colocação do material foram instalados pinos de titânio nas áreas, tanto controle, como no experimental, sendo um parâmetro de medição. Os resultados demonstraram uma quantidade intensa de osso preenchendo o alvéolo nas áreas experimentais e uma menor reabsorção em altura quando comparado com o controle, em relação a reabsorção horizontal, houve uma similar diminuição em ambos.

Em 2000, CORDIOLI; PUSTIGLIONI; GEORGETTI ${ }^{31}$ estudaram a reparação óssea alveolar pós-exodontia em cães, com ou sem o uso de membrana de PTFE-e, observaram que o tecido ósseo neoformado nos alvéolos apresentaram características de osso imaturo, tanto no lado com membrana quanto no lado sem membrana e os alvéolos mostraram um padrão de reparação óssea semelhante, com ou sem membrana. Porém nos casos onde a membrana sofreu deslocamento observou-se um retardo na reparação quando comparado aos demais.

CALIXTO et al. $^{26}, 2001$, testaram partículas de resina de mamona (AUG-EX; Poliquil Polímeros químicos, LTDA, Araraquara, SP) em alvéolo dental de ratos, para verificar a sua biocompatibilidade e a sua interferência na cronologia de reparo alveolar. Os resultados histológicos demonstraram a localização das partículas na região media e cervical que com o decorrer do período foi circundado por tecido conjuntivo frouxo e posteriormente por tecido ósseo, algumas células gigantes tipo corpo estranho aderidos à sua superfície. O reparo foi retardado em $13 \%$ a $20 \%$ com menor neoformação óssea.

Em 2001, ARTZI; NEMCOVSKY; TAL $^{7}$ publicaram a segunda parte do trabalho apresentado em 2000, onde utilizaram o osso bovino mineral poroso em alvéolos. A metodologia e material foram a mesma do primeiro 
artigo, exceto quando do processamento histológico, onde foi utilizado outro tipo de corante na avaliação da quantidade de osso lamelar em comparação ao osso medular na superfície, meio e profundidade dos espécimes. Em todos os métodos notou-se a neoformação óssea ao redor aderido ao material enxertado. Com o corante Tricômio de Mallory, observaram-se osteoblastos presentes com uma camada osteóide, entre as partículas de PBBM (porous bovine bone mineral) e o novo tecido ósseo. Com o Picro Sírius Vermelho observou-se um aumento de tecido ósseo na direção corono-apical. A quantidade de tecido ósseo na região superficial é de 17,1\% com proporção de $1: 12,9$ de osso lamelar/medular. Na região média a quantidade de osso foi 48,3\% com uma proporção 1:3,8 em um aumento ósseo de 63,9\% com proporção de 1:1,7 de osso lamelar/medular. As partículas do material não foram significantemente absovidas após 9 meses.

FROUM et al. ${ }^{42}$, 2002, compararam o vidro bioativo e o osso desmineralizado liofilizado quando utilizados em alvéolos dentários. Utilizaram 30 pacientes, divididos em 3 grupos de 10 indivíduos cada; um grupo recebeu o vidro bioativo, 10 receberam osso desmineralizado liofilizado e 10 com coágulo (controle). Após 8 meses, retirou-se uma amostra da área antes da colocação do implante. Na análise histológica observou-se que a quantidade de osso neoformado foi de 59,5\% com vidro bioativo, $34,7 \%$ com o osso desmineralizado liofilizado e 32, 4\% no controle. Não houve diferença estatística ao volume de osso neoformado, mas em relação ao material implantado residual foi significantemente maior no grupo com osso desmineralizado liofilizado (13,5\%) quando comparado ao vidro bioativo $(5,5 \%)$.

BRANDAO et al. $^{18}$, 2002, implantaram em alvéolos de ratos HA associada ou não a BMPs. Neste estudo utilizaram-se 45 ratos que foram divididos em 3 grupos de 15 animais: controle (não tratados), implantados com HA pura e implantados com HA acrescida de BMPs. Cinco animais de cada grupo foram sacrificados nos períodos de 7, 21 e 42 dias após procedimentos cirúrgicos. Realizadas análise histológica e histométrica, e observou-se que a reparo alveolar sofreu um atraso em ambos os grupos que receberam material (HA pura ou HA/BMPs), principalmente no grupo que recebeu HA/BMPs e no 
período de 21 dias, ou seja, ao comparamos com o grupo controle o reparo alveolar ficou atrasado com a utilização desses materiais.

NORTON et al. $^{72}$, 2003, avaliaram 15 pacientes, de uma clínica privada especilizada, os quais sofreram a extração dentária e colocação de Bio-Oss (Geistlich Pharma, Wolhusen, Switzerland). Após o tempo de reparo as áreas foram abertas e através de um trefina retiradas biopsias para análise histológica, avalinado assim a porcentagem de osso formado, o resto de BioOss, tecido conjuntivo na área e porcentagem de contato entre o enxerto e o tecido ósseo. A formação óssea foi de $26.9 \%$, a porcentagem de resto de BioOss foi de $25,6 \%$ e tecido conjuntivo foi de $47,4 \%$. A média do contato entre 0 Bio-Oss e o tecido ósseo foi de 34\%. A taxa de sucesso dos implantes colocados após a cicatrização completa dos enxertos foi de $97 \%$.

FISHER et al. ${ }^{38}$, 2004, utilizaram um gel de polímero hidrofílico em alvéolos de coelhos para impedir o processo de reabsorção e adesão celular. Após a remoção do inciso central o alvéolo foi preenchido com o biomaterial, os períodos experimentais foram 4 dias, 1, 2, 4 e 8 semanas após a cirurgia. Os animais foram sacrificados e realizados processamentos histológicos, obtendose lâminas coradas com hematoxilina e eosina, e realizou-se imunohistoquimica. Os resultados enfatizaram a necessidade de considerar as propriedades do biomaterial e os efeitos diferentes sobre os fatores de crescimento endógenos e a cicatrização óssea, juntamente com desenvolvimento da engenharia tecidual. 


\subsection{TESTES EXPERIMENTAIS EM CALVÁRIA DE RATOS}

Os biomateriais, antes de serem utilizados em humanos, necessitam de análises laboratoriais como teste de biocompatibilidade (subcutâneo de ratos), teste de formação óssea ectópica (intra-muscular de animais), evolução do reparo ósseo e a qualidade e quantidade óssea neoformada (calvaria de ratos).

Em 1981, GLOWACKI; ALTOBELLI; MULLIKEN ${ }^{45}$ avaliaram através de defeitos ósseos de $4 \mathrm{~mm}$ de diâmetro em calvária de ratos o fator de reparo ósseo, tipo celular presente nessas áreas enxertadas com osso mineralizado e desmineralizado alogênicos. Após 2 semanas verificaram um preenchimento do defeito em $100 \%$ no grupo desmineralizado e que através de histomorfometria, pequenas partículas deste biomaterial induziam mais a formação óssea do que as partículas de maiores tamanhos. Já no grupo mineralizado observaram reabsorção total do enxerto após 3 semanas sem o preenchimento total do defeito, encontrando muitas células multinucleadas e tecido conjuntivo.

BOSCH; MELSEN; VARGERVIK ${ }^{16}$, 1998, provocaram defeitos bilateralmente críticos de $5 \mathrm{~mm}$ em calvária de ratos Wistar, sendo que um lado serviu de controle, não recebendo nenhum tipo de material, enquanto que o outro lado recebeu um material osteopromotor. Os animais foram sacrificados após 6 e 12 meses pós-cirurgia e avaliados a formação e fechamento da calvária, classificando-os em fechamento total, parcial ou sem fechamento. Apos 6 ou 12 meses observaram um fechamento parcial dos defeitos no lado controle, apresentando somente tecido ósseo na periferia do defeito. Concluíram que a utilização de um defeito bilateral de $5 \mathrm{~mm}$ é eficaz como defeito crítico e possibilita uma avaliação pareada de materiais já que nessa dimensão de defeito podemos realizar na duas parietais do animal sem haver interferência de um lado do outro.

MAJZOUB et al. ${ }^{64}, 1999$, avaliaram a influência da perfuração da cortical externa da calvária no reparo ósseo, realizando defeitos bilaterais circulares, com auxílio de uma trefina nas calvárias de ratos, penetrando 
somente $1 \mathrm{~mm}$ na cortical de ambos os lados: no lado teste, realizou-se perfurações na cortical externa da calvária com auxilio de brocas esféricas, com a finalidade de criar uma comunicação da região do osso medular da calvária com o espaço criado acima com uma cápsula de titânio de préfabricada de 4,8 $\mathrm{mm}$ de diâmetro e altura de 3,0 mm; no lado controle colocouse somente a cápsula. Com isso avaliar-se-ia a influência do tecido medular na formação óssea em áreas confinadas, ou seja, áreas que receberam exclusivamente nutrição da cortical externa ou do medlua óssea. Os animais foram sacrificados em 10, 21, 42 e 60 dias, sendo avaliada a formação óssea pela análise de histomorfometria. Foi observada também uma maior neogênese em todos os períodos no grupo teste (perfuração do cortical influência da medula) quando comparado ao grupo controle e, quanto à densidade, esta foi maior no grupo teste do que no grupo controle, ou seja, tem-se uma influência positiva da medula na regeneração óssea, acelerando este processo e aumentando a quantidade e qualidade de tecido ósseo neoformado.

VERHEGGEN; MERTEN ${ }^{109}$, 2001, na área médica, realizaram um trabalho clínico e experimental em animais (mini-porcos) avaliando um cimento de hidroxiapatita em defeitos em calvária. Avaliaram-se 10 pacientes que necessitavam de enxertos na área do crânio e que receberam o cimento de hidroxiapatita. Esta avaliação foi através de radiografias após 6 meses do enxerto; no caso dos animais, estes foram sacrificados após 12, 18 e 40 semanas após a cirurgia. Histologiacamente (através dos porcos) observou-se que houve uma total reabsorção do cimento de hidroxiapatita após 40 semanas acompanhadas de uma formação de tecido ósseo na área, sem a perda no tamanho ou volume ósseo. Clinicamente (em humanos), não houve caso de hematoma ou fístula pós-operatória, após 6 meses da cirurgia o cimento de hidroxiapatita mostrou-se densamente radiopaco nas radiografias.

VERNA et al. ${ }^{110}$, 2002, avaliaram o padrão de cicatrização em defeito ósseos em calvária de ratos seguidos de regeneração tecidual guiada, por meio de uma análise de varredura por micro-CT, induzindo defeitos críticos em 48 ratos machos Wistar, que receberam membrana de politetrafluoretileno 
expandida (PTFE-e) oclusiva exo e endocranial (OO; $n=12)$; outro grupo recebeu uma membrana oclusiva exocranial e uma membrana perfurada endocranial (OP; $n=12$ ); uma membrana perfurada exocranial e uma membrana (PP; $n=12$ ). Os animais foram sacrificados após 4 semanas e observou-se que havia um volume ósseo de 31,4\%(OP) e 24,5\%(PP). A fração volumétrica óssea e mineralização na área média foi significantemente maior no grupo OP do que o grupo PP e na área central o grupo $\mathrm{OO}$ e PO foram maior do que o grupo PP, sugerindo que o uso de uma membrana oclusiva de PTFE-e aumenta a formação óssea e maturação do esqueleto da calvária.

O alvo do estudo de MARDAS; KOSTOPOULOS; KARRING ${ }^{65}, 2002$, foi avaliar o efeito da regeneração tecidual guiada (RTG) sozinho, implantação da matriz ossea desmineralizada (DBM) sozinho e do tratamento combinado na cicatrização dos defeitos em crânios que envolvem a sutura cranial sagital, buscando avaliar o crescimento da calvária subseqüente. Sessenta ratos foram usados no estudo e foram distribuídos aleatòriamente em cinco grupos (A-E) de 12 animais. Em quatro grupos (A-D), foram realizados defeitos nas calvárias (5.0 milímetros) que envolviam a sutura sagital, trabalhando da seguinte forma: Grupo A: defeito deixado sem tratamento. Grupo B: DBM implantado no defeito. Grupo C: dura-máter e o defeito superficial coberto com uma membrana do PTFE-e. Grupo D: defeito tratado com a técnica de dupla membrana combinada com a implantação de DBM. Grupo E: Os animais eram operados sem a realização de defeito. Em todos os grupos, dois pontos de guta-percha foram colocados para indicar as beiras laterais dos ossos parietais. Análise histológica foi realizada após 4 meses pós-cirurgia mostrou que os defeitos cranial sem tratamento $(A)$ cicatrizaram com a presença de um tecido conjuntivo fibroso na porção mediana do defeito. Os defeitos enxertados com DBM (B) cicatrizaram completamente contendo partículas de DBM ou parcialmente com osso e o tecido conjuntivo. Os defeitos (D) tratados com o DBM combinado com o RTG cicatrizaram completamente com o osso, quando os defeitos $(\mathrm{C})$ foram tratados com as membranas sozinhas cicatrizaram com osso, mas a sutura estava com tecido similar à sutura sagital normal dos animais do grupo controle (E) sempre presente na porção mediana do defeito. A radiografia cefalométrica demonstrou que o grupo tratado com membrana (C) 
e os animais controle (E) exibiram o crescimento coronal similar do crânio depois do tratamento. Os resultados demonstraram que a cicatrização óssea incluiu uma formação da sutura sagital podendo ser realizado em defeitos em calvária pela técnica da RTG, e o crescimento ósseo da calvária não é uniforme. O tratamento dos defeitos com o DBM sozinho ou o DBM combinado com a RTG resulta na crâniosinostose e um crescimento cranial reduzido.

FOWLER et al. ${ }^{39}$, 2002, avaliaram a evolução do polióleo plurônico como carreador para materiais de enxerto em calvária de ratos. Os polióleos plurônicos são uma família dos agentes de superfícies ativos não-iônico usados atualmente como carreadores de droga para os agentes do antibiótico, antiinflamatórios e anti-neoplásicos. A administração terapêutica desses agentes de superfícies ativos não-iônico facilita a síntese do colágeno e microcirculação, promovendo assim a cicatrização da ferida. Cento e cinqüenta (150) ratos Sprague Dawley machos com a idade de 95 a 105 dias, com peso entre 375 e $425 \mathrm{~g}$ foram distribuídos aleatoriamente e uniformemente em 15 grupos de diferentes tratamentos. Foram anestesiados e foram realizados defeitos críticos na calvária (8 milímetros). Pluriônico F-68 (F-68) ou Pluriônico F-127 (F-127) foram administrados topicamente ou sistemicamente e associado com pó de osso desmineralizado (DBP), trifosfato de cálcio (TCP), ou sem enxerto (controle). Os polióleos pluriônicos são misturados facilmente com o DBP ou o TCP para melhorar a administração do material. As calvárias foram colhidas após 12 meses pós-cirurgia e avaliados histomorfometricamente e radiograficamente pelo contato radiográfico com subseqüente análise de densitometria, através de espectrometria de energia que utiliza um microscópio de elétron de exploração, e por fluorescência microscópica. Nos resultados observaram-se uma diferença significativa na porcentagem do osso preenchido entre o controle, grupos do TCP, e do DBP $(p<0,05)$. A única diferença significativa dentro de todos os grupos foi entre controle do TCP e o TCP mais F-127 sistêmico $(p<0,05)$. Embora houvesse diferenças isoladas, a tendência total era que o polióleo pluriônico e o modo de administração não resultassem em uma mudança significativa no processo de cicatrização óssea medidos pela porcentagem de osso preenchido. Os polióleos pluriônicos podem ser considerados como carreadores para materiais de enxerto ósseo. 
AHN et al. ${ }^{2}, 2003$, realizaram um estudo avaliando o efeito da proteína morfogenética recombinante óssea humana-4 (rhBMP-4) como carreadora em defeitos em calvária de ratos. As proteínas morfogenética do osso (BMPs) estão sendo avaliadas como candidatos para a terapia regenerativa periodontal e óssea. Entretanto, as pesquisas sobre a proteína morfogenética recombinante óssea-4 (rhBMP4) são insuficientes para avaliar sua capacidade real na formação óssea e o seu efeito carreador. Foram realizados defeitos (8 $\mathrm{mm}$ de diâmetro) nas calvárias de 100 ratos Sprague Dawley machos e os animais foram divididos em 5 grupos ( $n=20$ animais). Os defeitos do lado direito foram tratados com rhBMP-4 associado com uma esponja de colágeno absorvível (ACS) $(0,05 \mathrm{mg} / \mathrm{mL}$ de rhBMP-4), rhBMP-4 associado com Fosfato tricálcio B (B-TCP) $(0,05 \mathrm{mg} / \mathrm{mL}$ de rhBMP-4, ACS sozinha, $B$-TCP sozinha e o lado esquerdo de todos os animais permaneceram sem tratamento. Os ratos foram sacrificados após 2 ou 8 semanas da cirurgia, e os resultados foram avaliados pela radiodensitometria, histologicamente, e histomorfometricamente. Para a radiodensitometria o grupo de rhBMP-4/ACS e o rhBMP-4/B-TCP foram mais radiopacos que os outros grupos tanto para 0 período de 2 ou 8 semanas $(P<0,01)$. Histologicamente, os grupos de rh/BMP4/ACS e o rhBMP-4/ß-TCP apresentaram uma formação óssea maior em ambos os períodos quando comparados aos outros grupos. Os resultados histomorfométricos demonstraram que os grupos rh/BMP-4/ACS e o rhBMP4/B-TCP obtiveram maior porcentagem de osso formado em ambos os períodos quando comparados aos demais grupos $(p<0,01)$. A implantação cirúrgica de rhBMP-4/ACS pode ser usado como suporte para regeneração óssea em defeitos críticos na calvária de ratos, e o rhBMP-4/ rh/BMP-4/ACS e o rhBMP-4/B-TCP podem permitir uma regeneração óssea em defeitos de calvária de ratos sem complicações, demonstrando que ambos biomateriais podem servir como carreadores para as rhBMP-4.

RUPPRECHT et al. ${ }^{87}, 2003$, avaliaram o reparo de defeito crítico em calvária de mini-porcos de Goettingen com a utilização de um cimento de hidroxiapatita (BoneSource ${ }^{\mathrm{TM}}$ ). O BoneSource ${ }^{\mathrm{TM}}$ foi aplicado em defeitos bicortical de vários tamanhos nas testas de seis mini-porcos de Goettingen, possibilitando a utilização deste material em blocos de tamanhos diferenciados. 
As áreas foram avaliadas radiográfica e histologicamente após 12, 18 e 40 semanas pós-operatório. Após 40 semanas aproximadamente $90 \%$ do cimento de hidroxiapatita foi absorvida e substituída por osso. Após 12 semanas, aproximadamente $30 \%$ tinham sido degradados, e $40 \%$ após 18 semanas. Em defeitos ósseos pequenos, a mucosa da cavidade óssea frontal alinhou o substituto do osso (BoneSource ${ }^{\mathrm{TM}}$ ). Em reconstruções de grandes áreas, uma membrana foi usada para estabilizar o material. Apesar desta sustentação pela membrana, o material de BoneSource ${ }^{\mathrm{TM}}$ sofreu um colapso na cavidade óssea frontal. Observa-se que o cimento de hidroxiapatita pode ser utilizado para reparo de defeitos ósseos e moldado para dar forma nas reconstruções, porém seu uso é limitado ao tamanho do defeito e pela necessidade de um leito propicio. Por tanto, o BoneSource ${ }^{\mathrm{TM}}$ serve bem para reparar defeitos pequenos com biocmpatibilidade comprovada, entretanto, em defeitos grandes, o material não é suficientemente estável.

FRANCIS et al. ${ }^{41}$, 2003, avaliaram neste trabalho um material aloplástico ósseo regenerativo em calvária de ratos. Aloplástico é um corpo estranho inerte que age como mantenedor de espaço osteocondutor durante a cicatrização óssea, pode também funcionar como carreador para o fator de crescimento que possuem a função de melhorar a neovascularização e o osteoindução; o fator de transformação de crescimento humano recombinante B (rhTGF-B1) é um desse fatores. A finalidade do estudo foi avaliar grânulos divinil estireno (DVSb) na regeneração óssea em calvária de rato num modelo de defeito critico. Os grânulos de di-vinil estireno (DVSb) com ou sem rhTGF-ß1 foram colocados entre a membrana de filme gel em defeitos críticos em calvária de ratos (Rattus norvegicus). Preenchimento ósseo; porcentagem de preenchimento ósseo; taxa de formação óssea (TFO); e mineralização em 3, 6 e 12 semanas pós-cirurgia foram mensurados usando densitometria, histomorfometria, microscopia eletrônica de varredura e marcação com teraciclina - $\mathrm{HCl}$. A média da densidade e da porcentagem foram estatisticamente maior para os grupos com tratamento de DVSb em comparação ao grupo controle $(P=0,05)$. A taxa de formação óssea foi consistente entre 3 e $7 \mu \mathrm{m}$ para todos os grupos; o grupo aloplástico teve uma taxa de formação óssea significativamente maior na 6 semanas $(P=0,05)$; 
entretanto, em 3 e 12 semanas, a taxa de formação óssea no grupo controle, o material ósseo de preenchimento era maior do que os grupos com tratamento $(P=0,05)$. As membranas frequentemente colabaram e pouco preenchimento ósseo ou mineralização ocorreu nos defeitos sem DVSb. A mineralização aparentemente ocorreu adjacente ao aloplástico no período de 12 semanas, visto nos cortes histológicos e microscopia eletrônica de varredura. No DVSb ocorreu um ligação fibrosa em alguns espécimes, não havendo evidências de resposta inflamatória. O DVSb com ou sem rhTGF-B1 aumentou significantemente a regeneração óssea no modelo de defeito crítico em calvária de ratos.

MATZENBACHER et al. ${ }^{67}, 2003$, realizaram um estudo in vivo da efetividade de uma composição de glicerol com osso desmineralizado e liofilizado xenogênico em calvária de ratos. O osso desmineralizado liofilizado (DFDB) geralmente é hidratado com água esterilizada formando uma consistência de pasta, melhorando a manipulação clínica ou utilizada com barreiras biodegradáveis, tais como o glicerol, para promover estabilidade da ferida de cirurgias periodontais humana. Para esta pesquisa foram utilizados 48 (quarenta e oito) ratos Sprague Dawley do gênero masculino e adulto que foram divididos em 4 grupos $(n=12)$ de acordo com o tratamento realizado: glicerol, DFDB, DFDB mais o glicerol, ou controle sem enxerto. Os materiais foram implantados em defeitos críticos ( $8 \mathrm{~mm}$ de diâmetro) nas calvárias dos animais e coletadas após 8 semanas da cirurgia e avaliados histomorfometricamente. Um aumento significantemente estatístico de preenchimento de osso foi detectado no grupo de glicerol/DFBA quando comparado com os demais grupos e obteve-se ainda uma diferença estatística entre os grupos DFBA > glicerol > grupo controle. Nenhuma diferença significativa foi anotada entre o grupo DFDB/glicerol e o grupo com somente DFDB. A adição do glicerol ao DFDB resulta na regeneração óssea comparável ao DFDB sozinho e baseado em um julgamento clínico, características do DFDB foram grandemente melhoradas.

LEE et al. $^{62}$, 2003, através do conceito de regeneração tecidual guiada, realizaram um experimento em calvária de ratos para avaliar o efeito da 
BMP-2 adjunto a uma membrana bioabsorvível. Foi utilizado $5 \mu \mathrm{m}$ de rhBMP-2 dentro de um membrana na forma de redoma esférica feita de poli (L-lactico) e fosfato tricálcio (PPLA/TCP). A cinética de liberação de rhBMP-2 da membrana foi determinada in vitro usando uma BMP-2 humana recombiante. Doze membranas com rhBMP-2 (grupo teste) e 12 membranas controles (grupo controle) foram colocadas num defeito parcial em espessura na calvária de 24 coelhos. Os animais foram sacrificados após 4 e 8 semanas da cirurgia e descalcificadas para preparação das lâminas histológicas. A área de formação óssea e altura foram mensuradas por histomorfometria e calculada pela taxa de porcentagem do total do espaço submembranoso e altura abaixo da membrana. Os resultados in vitro da liberação demonstraram que rhBMP-2 foi consistentemente liberado sobre um período de 4 semanas seguindo uma liberação elevada inicial no primeiro dia. Em 4 e 8 semanas, a análise histomorfometrica revelou que o grupo teste mostrou alturas e áreas maiores estatisticamente significante do que o grupo controle $(p<0,01)$. No grupo controle, a altura do novo osso formado foi de 36,3\% da altura membrana e a área do novo osso formado alcançou $8,2 \%$ da área submembranosa do espaço em 8 semanas, enquanto que o grupo do teste alcançou $87.3 \%$ e $35.4 \%$, respectivamente. Estes resultados sugerem que 0 uso das membranas associadas com o rhBMP- 2 PLLA/TCP pode resultar no aumento adicional do osso, devido às propriedades osteoindutoras do rhBMP-2 liberadas da membrana durante a cicatrização.

FERREIRA et al. ${ }^{37}, 2004$, utilizando o defeito crítico em calvária de ratos avaliaram a capacidade da formação óssea pela BMP bovina associada com uma hidroxiapatita microgranular bioabsorvível. Um defeito de 8 milímetros do diâmetro foi criado na calvária de 25 ratos, sendo que em 15 ratos os defeitos foram preenchidos com o BMPb-HA homogeneizados com sangue (grupo experimental), e em 10 ratos os defeitos foram preenchidos somente com os coágulo sangüíneo (controle). Os calvárias dos ratos experimentais foram coletados 1, 3 e 6 meses após a cirurgia e dos ratos do grupo controle a coleta foi feita ao fim da cirurgia (imediato) e após 6 meses da cirurgia. Os resultados morfogenéticos obtidos nas radiografias mostraram uma ausência da formação óssea em 1 e 3 meses pós-cirurgia e, histologicamente, os 
defeitos foram preenchidos com o tecido conjuntivo fibroso e numerosos focos de corpo estranho em torno dos aglomerados de hidroxiapatita. No fim de 6 meses, o número e o tamanho dos focos granulomatosos diminuíram e a área dos defeitos foi reduzida por $22 \%$ quando comparado ao controle de 0 horas, devido à formação do osso novo em suas bordas, embora a média da área fosse similar ao controle de 6 meses. O uso do BMPb-HA no tratamento de defeitos críticos do osso de tamanho crítico de ratos conduz à formação de corpo estranho e uma reação granulomatosa que inibe a formação óssea, sugerindo que o hidroxiapatita microgranular sintética não representa um bom carreador para as BMPs na formação óssea.

TAMURA et al. ${ }^{98}, 2005$, avaliaram a regeneração óssea através de um tampão de titânio oclusivo na calvária do coelho usando imagens de tomografia computadorizada microfocada. Em 10 coelhos, as calvárias foram expostas e um sulco circular foi preparado. Após ter penetrado na medular, um tampão de titânio hemisférico padrão foi colocado no sulco e coberto com retalho cutâneo. Após 1 ou 3 meses, os animais foram sacrificados e as calvárias e os tampões de titânio foram dissecados. Após a tomada das imagens de tomografia computadorizada microfocada, cortes histológicos foram realizados. Os espécimes foram observados usando as imagens tridimensionais construídas das imagens da tomografia computadorizada microfocada, e os cortes histológicos foram examinados para obter parâmetros do osso. As imagens tridimensionais e os espécimes histológicos mostraram que o osso formado foi na forma plana, na forma de copo, e na forma da abóbada. Os parâmetros ósseos como a espessura trabecular e a proporção do espaço medular através da capacidade do tampão de titânio aumentaram, visto que a densidade do osso diminuiu, e houve diferença significante entre os grupos do 1 e 3 meses. O osso trabecular formou-se ao longo das paredes da cápsula de titânio, e houve preenchimento de osso na cápsula em 3 meses.

PRYOR et al. ${ }^{80}$, 2005, realizaram uma avaliação radiográfica da formação local de osso, seguido da implantação cirúrgica de um preparado de PRP usando um modelo do defeito na calvária de rato de tamanho critico. Trinta ratos Sprague Dawley masculinos com 22 semanas de idade foram 
usados. A preparação de PRP foi obtida de $10 \mathrm{~mL}$ do sangue extraídos de um rato fornecedor. Usando técnicas assépticas, a preparação de PRP foi embebida em uma esponja de colágeno absorvível (ACS) ou ACS sozinho implantado cirurgicamente em defeitos críticos 6 milímetros do lado contralateral da calvária do rato $(n=18)$. Doze animais receberam ACS sozinho contra cirurgia controle contralateral. Os animais foram sacrificados em 4 e 8 semanas após a cirurgia e foram coletados as calvárias, obtidas as radiografias. Setenta e cinco por cento dos sítios (PRP/ACS ou ACS) mostraram o fechamento parcial em 4 semanas; um sitio (ACS) exibiu fechamento completo sem diferenças entre o protocolo $(p=0,1797)$. Cinqüenta por cento dos sítios que receberam PRP/ACS exibiram completo fechamento, $20 \%$ fechamento parcial e 30\% não tiveram o fechamento em 8 semanas, enquanto que no grupo que recebeu somente ACS tivemos valores de $20 \%$ para o completo fechamento e $80 \%$ para fechamento incompleto ( $P=0,07532)$. Não havia nenhuma diferença notável entre os sítios que recebem ACS contra a cirurgia controle em 4 ou 8 semanas. Os resultados sugerem que a preparação de PRP não tem um efeito significativo na osteogênese.

HYUN et al. ${ }^{55}$, 2005, analisaram e compararam a atividade de formação óssea das rhBMP usando um modelo pré-clinico são limitadas. Conseqüentemente, o objetivo do estudo foi avaliar e comparar o potencial osteogênico da rhBMP-2, de -4, e de -7 carreada por uma esponja de colágeno absorvível (ACS) em casos precoces (2 semanas) e finais (8 semanas) de cicatrização dos defeitos críticos em calvária de ratos. Os defeitos foram feitos sob medida crítica de $8,0 \mathrm{~mm}$ em 30 ratos Sprague Dawley masculinos. Os animais foram divididos em três grupos de 10 animais cada um. Os defeitos foram tratados com os $0.025 \mathrm{mg} / \mathrm{ml}$ rhBMP-2/ACS, rhBMP-4/ACS, ou rhBMP7/ACS. Os ratos foram sacrificados em 2 ou 8 semanas $(n=5$ para cada período) após a cirurgia, e os resultados foram avaliados histologicamente, histomorfometricamente, e imunohistoquimicamente. A implantação cirúrgica de rhBMP-2/ACS, de rhBMP-4/ACS, ou de rhBMP-7/ACS resultou na formação local de osso nos defeitos dos ratos em 2 e 8 semanas. A quantidade de fechamento do defeito, a área nova de osso e a densidade foram similares nos três grupos em cada período $(P>0.05)$. Em relação a densidade do osso e a 
área nova do osso, houve diferença estatisticamente significante entre os resultados obtidos em 2 semanas e os aqueles obtidos em 8 semanas em todos os grupos $(P<0,05)$. Análise de variação a dois critérios (ANOVA) revelou que não há nenhuma correlação entre o tempo e as condições $(P>$ 0,05), mas o tempo demonstrou ter uma forte influência no fechamento do defeito, na área nova do osso e na densidade do osso $(P<0,05)$. Indiferente ao tipo do rhBMP, houve uma resposta positiva na imunoreação para o osteopontin (OPN) e de osteocalcin (OCN) em 2 e 8 semanas. Intenso OPN e marcações de OCN foi observado perto do osso neoformado como também algumas celulas dentro do osso neoformado. Dentre os tipos de rhBMP usados, a concentração do rhBMP e o intervalo da observação não parecem influenciar diretamente no potencial regenerativo do osso. Todas as rhBMPs usadas neste estudo podem ser consideradas fatores eficazes para induzir a formação óssea.

PANG et al. ${ }^{76}, 2005$, avaliaram in vitro o efeito de citosan com fibroblastos do ligamento periodontal humano (hPDLF) na formação óssea em defeitos de calvárias de rato. As populações de fibroblastos foram obtidas de indivíduos com um periodonto saudável. Para os grupos experimentais, as células foram cultivadas nas concentrações de 0,$01 ; 0,1 ; 1,0 ;$ ou $2,0 \mathrm{mg} / \mathrm{ml}$. Os 3-(4,5-dimeti-tiazole-2-yl)-2,5-difenil brometo de tetrazolio (MTT), a reação da cadeia da transcrição-polimerase reversa (RT-PCR) e a atividade da fosfatase alcalina (ALPase) foram executados. Foram realizados defeitos de $8 \mathrm{~mm}$ na calvária de 30 ratos Sprague Dawley masculinos. Os animais foram divididos em três grupos de 10 animais. Os defeitos foram tratados com esponja de citosan/esponja de colágeno absorvível (ACS) ou o ACS sozinho nos grupos experimentais ou deixados sem tratamento (controles cirúrgicos). Os animais foram sacrificados em 2 ou 8 semanas pós-cirurgia e os resultados do tratamento foram avaliados usando parâmetros histológicos e histomorfométricos. As respostas proliferativas induzidas pelo citosan do hPDLF alcançaram um platô em uma concentração de $0.1 \mathrm{mg} / \mathrm{ml}(P<0,05)$. Quando o hPDLF foi estimulado com $0.1 \mathrm{mg} / \mathrm{ml}$ de citosan, tanto a expressão do mRNA do colágeno tipo I quanto a atividade ALP foi significantemente maior $(P<0,05)$. A implantação cirúrgica de citosan/ACS aumentou a formação 
óssea no período de 8 semanas pós-cirugia e uma quantidade de formação de tecido ósseo no grupo citosan/ACS foi significantemente maior do que ambos os grupos, controle e ACS sozinho $(P<0,01)$. A área do novo osso $e$ fechamento do defeito no grupo de citosan/ACS foram significantemente maior do que o grupo somente com ACS e o grupo controle no período de 8 semanas $(P<0,01)$. Entretanto, o grupo citosan/ACS exibiu significante perda de densidade óssea que o grupo com somente ACS e o grupo controle no período de 8 semanas $(P<0,01)$. Citosan $(0,1 \mathrm{mg} / \mathrm{mL})$ aumentou a síntese de colágeno tipo I e facilitou a diferenciação de células osteogênicas. Citosan junto com ACS tem um significante potencial de acelerar a regeneração óssea em defeitos críticos em calvária de ratos.

HAN et al. ${ }^{48}$, 2005, avaliaram a possibilidade de um sistema de selamento de fibrina-fibronectina (FFSS) como um carreador para uma BMP-4 recombinante humana (rhBMP-4) e avaliar o potencial osteocondutor do FFSS em um defeito em calvária de rato, com $8 \mathrm{~mm}$ de diâmetro e foi realizado em 30 ratos Sprague Dawley masculinos. Três grupos de 10 animais, sendo os grupos assim constituídos: rhBMP-4 (0.025 mg/ml) em FFSS, de FFSS controle, ou cirurgia controle. Os grupos foram avaliados usando os parâmetros histológicos e histométricos que seguem intervalos de cicatrização de 2 e 8 semanas (cinco animais por o grupo por intervalo de cicatrização). A implantação cirúrgica de rhBMP-4/FFSS resultou na formação local de osso em 2 e 8 semanas. A formação nova do osso era também evidente no controle de FFSS; entretanto, a quantidade de fechamento do defeito, de área nova do osso, e de densidade do osso era significativamente maior no grupo de rhBMP4/FFSS ( $\mathrm{P}<0,05)$. Em 8 semanas, a quantidade do osso novo era maior do que aquela observada em 2 semanas, e os espécimes mostraram um estágio mais avançado de remodelação e consolidação em ambos os grupos $(P<$ $0,05)$. Somente no controle observou-se uma formação muito limitada de osso. Os resultados do estudo atual indicaram que o FFSS tem o potencial osteocondutor e pode ser empregado como um carreador para as BMPs.

PRYOR; SUSIN; WIKESJO ${ }^{81}$, 2006, validaram as avaliações radiográficas de formação de osso em um modelo de defeito ósseo em calvária 
de ratos em tamanho critico (6 milímetros). Foi realizada osteotomia bilateral em 30 ratos Sprague Dawley adulto tratados com PRP preparado de ratos controle, e foram avaliados por medidas radiográficas e histológica depois de 4 ou 8 semanas após cirurgia. A parcela mais central de cada local do defeito era sujeita à análise histológica usando um sistema de analise de imagem PC. As avaliações radiográficas da formação do osso são associadas com as fraquezas significativas que representam o evento atual de cicatrização; $k$ = 0.17 que denota um ligeiro acordo além da possibilidade. Perfeita concordância entre a análise histológica e radiográfica para os locais do defeito que mostraram completo ou parcial preenchimento ósseo que foi de $63 \%$ e $50 \%$ de acordo com os tempos, respectivamente. A concordância alcançou somente $20 \%$ para locais com nenhum ou limitado preenchimento ósseo. Quando nenhum ou limitado preenchimento ósseo ocorreu, a análise radiográfica tendeu a sobreestimar o preenchimento ósseo. Quando ocorreu o preenchimento completo dos locais de defeito houve uma subestimação. A exatidão baixa foi observada quando as avaliações radiográficas foram empregadas para identificar e caracterizar o preenchimento dos defeitos ósseos na calvária dos ratos. Avaliação do osso formado no modelo animal deve ser avaliada através de análises histológicas e não somente radiográficas.

TAMIMI et al. ${ }^{97}$, 2006,compararam a capacidade da regeneração óssea de um carreador de Fosfato tricálcio-ß (ß-TCP)/Fosfato dicálcio hidratado (DCPD) sintetizado no laboratório e Bio-Oss. Foram fixados 2 cilindros de titânio de cada lado da calvária de 14 coelhos de Nova Zelândia: um cilindro foi deixado vazio (controle negativo) e o outro foi preenchido com os grânulos de Bio-Oss ou B-TCP/DCPD (cilindro de teste). Quatro semanas após a intervenção, os animais foram sacrificados e as biópsias foram para exame. Os seguintes parâmetros foram analisados: aumento de tecido ósseo, densidade do osso e reabsorção de minerais do biomaterial. A comparação dos dados entre os grupos foi executada usando o teste de Mann-Whitney com um nível de significância de $\mathrm{p}<0,05$. A média da densidade mineral do osso e o aumento de tecido mineral dentro dos cilindros testes foram similares, mas maiores do que o controle negativo. A reabsorção do material e aumento de tecido ósseo foram significantemente maiores nos defeitos tratados com B-TCP/DCPD 
$(p<0,05)$. Os grânulos de B-TCP/DCPD foram mais reabsorvíveis e geraram maior tecido ósseo do que Bio-Oss dentro dos cilindros de titânio colocados em calvária de coelho.

HONG et al. ${ }^{51}, 2006$, avaliaram o efeito osteogênico de um sistema fibrina-fibronectina (FFSS) combinado com o Fosfato tricálcio-ß (B-TCP) como um sistema de carreador para as proteínas morfogenéticas de osso humano recombinante (rhBMP-2) em defeitos na calvária de ratos de $8 \mathrm{~mm}$. Foram utilizados 100 ratos Sprague Dawley masculinos, divididos em cinco grupos de 20 animais. Os defeitos foram tratados com o rhBMP-2/FFSS, o rhBMP2/FFSS/b B-TCP, FFSS e de FFSS/ B-TCP como carreador controle ou o lado esquerdo não foi tratado, servindo como controle. Os defeitos foram avaliados por parâmetros histológicos depois do 2 e 8 semanas após a cirurgia (10 animais do grupo para cada intervalo de cicatrização). O grupo FFSS/b-TCP foi significativamente maior na área em osso novo em 2 semanas $(p<0,05)$ e na área de tecido novo em 2 e 8 semanas $(p<0,01)$ comparado ao grupo FFSS. $O$ osso novo e a área nova do tecido no grupo de rhBMP-2/FFSS/ B-TCP foi significativamente maior do que no grupo de rhBMP-2/FFSS em 8 semanas $(p<0,01)$. Na observação histológica, os restos de FFSS estavam presentes no período de 2 semanas, mas nos de 8 semanas, o FFSS pareceu estar totalmente reabsorvido. O rhBMP-2 associado com FFSS/B-TCP produziu significantemente mais osso novo e tecido na calvária de ratos. Na conclusão, FFSS/B-TCP pode ser considerado como um carreador disponível para rhBMP2.

JUNG et al. ${ }^{58}, 2006$, realizaram um estudo variando o tamanho das partículas de B-TCP associados com um rhBMP-4 em calvária de ratos, foram utilizados 100 animais da raça Sprague Dawley masculinos. Cinco grupos de 20 animais: rhBMP-4 $(2,5 \mu \mathrm{g})$ usando B-TCP com partículas de 50 a $150 \mu \mathrm{m}$, rhBMP-4 $(2,5 \mu \mathrm{g})$ usando B-TCP com partículas de 150 a $500 \mu \mathrm{m}$, um controle de B-TCP com partículas de tamanho 50 a $150 \mu \mathrm{m}$, controle de B-TCP com partículas de 150 a $500 \mu \mathrm{m}$, ou uma cirurgia controle, sendo avaliados por medidas histológicas e parâmetros histomorfométricos, através dos períodos de 2 e 8 semanas de cicatrização. Não houve nenhuma diferença significativa 
no fechamento do defeito, na área nova do osso, ou no aumento da área entre os dois grupos de rhBMP-4/b-TCP ou entre os dois grupos controles de B-TCP (50 a $150 \mu \mathrm{m}$ e 150 a $500 \mu \mathrm{m}$ ) em 2 e 8 semanas. A rhBMP-4 combinada com partículas pequenas ou grandes de B-TCP teve um efeito significativo na indução da formação do osso comparada ao controle de ß-TCP com partículas pequenas ou grandes ou do controle cirúrgico. Dentro dos parâmetros do estudo, variar o tamanho de partícula do ß-TCP não parece ter um efeito significativo na formação do osso.

POEHLING et al. ${ }^{79}$, 2006, avaliaram a associação (MD05) entre um ß-TCP revestido com uma fator de crescimento/diferenciação humana recombinante (rhGDF-5), como um material osteoindutor e osteocondutor. Utilizou-se ratos adultos Sprange Dawley, realizando defeito críticos $(6,0 \mathrm{~mm}$ de diâmetro) dos dois lados da calvária e os grupos foram divididos de acordo com o material utilizado: 1) MD05; 2)osso bovino mineral; 3) osso bovino e colágeno; 4)osso bovino mineral e peptídeo sintético; 5) ß-TCP (de dois fabricantes diferentes); ou 6) sem material de preenchimento. Análise cega macroscópica, análise histopatológica, e análise histomorfométrica foram realizadas 6 semanas após o implantação. A formação de osso novo, quando avaliada histomorfometricamente, foi aproximadamente cinco vezes maior com MD05 do que com os outros substitutos ósseos testados, e o reparo ósseo foi bem avançado nos defeitos preenchidos com MD05 após 6 semanas. A extensão do tecido fibroso e os grânulos residuais foram significativamente mais baixos no grupo MD05. Em contraste aos outros materiais, o uso de MD05 foi associado a uma completa ossificação do defeito e com presença de uma medular normal. O efeito osteoindutor do rhGDF-5 foi aparente e houve um grande crescimento ósseo com o MD05 comparado com o carreador de ßTCP sozinho, e todos os materiais demonstraram boa biocompatibilidade. MD05 conseguiu uma regeneração óssea superior quando comparada aos materiais convencionais e se demonstrou ser um promissor substituto ósseo para a aplicabilidade odontológica e maxilofacial. 


\subsection{COMPORTAMENTO MECÂNICO DOS OSSOS}

Devido à função estrutural que os ossos desempenham nos animais vertebrados, eles são constantemente submetidos a diversos tipos de esforços, à semelhança de uma estrutura utilizada na engenharia. Portanto, o estudo do comportamento mecânico dos ossos pode ser realizado usando os mesmos princípios e conceitos utilizados na engenharia.

As propriedades mecânicas definem o comportamento de um material, quando sujeito a esforços de natureza mecânica e correspondem às propriedades que, num determinado material, determinam a sua capacidade de transmitir e resistir aos esforços aplicados, sem se romper ou sem que se produzam deformações incontroláveis.

A relação entre a carga aplicada em uma estrutura e a deformação em resposta à carga pode ser observada em uma curva traçada num gráfico "carga $x$ deformação", ou, num gráfico "tensão $x$ deformação" quando a estrutura ensaiada for um corpo de prova com dimensões conhecidas. Esta curva pode ser dividida em duas regiões: a região de deformação elástica (fase elástica) e a região de deformação plástica (fase plástica). O limite entre as duas regiões é chamado de limite de proporcionalidade ou limite elástico (Figura 1). 


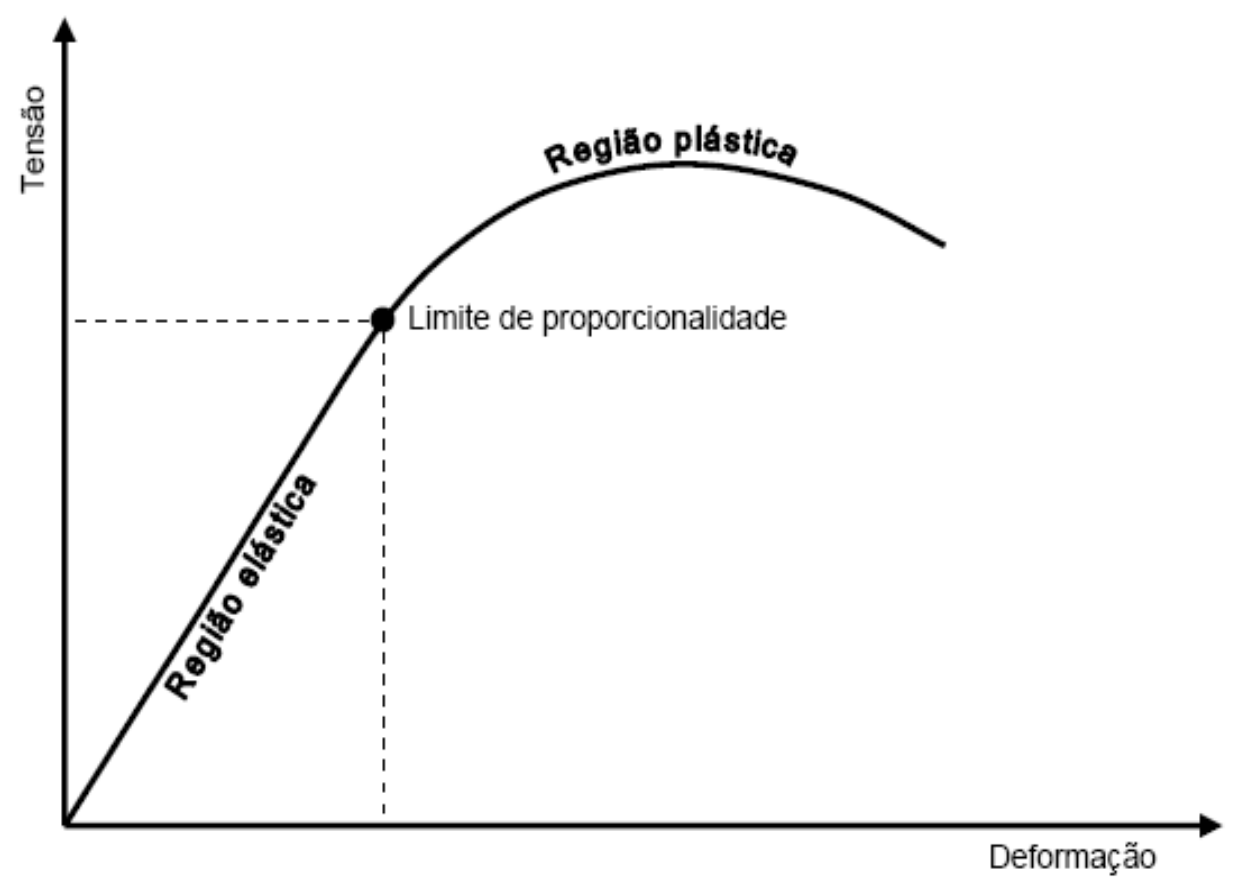

Figura 1 - Desenho teórico representativo das regiões de deformação elástica e plástica observadas em uma curva teórica tensão $x$ deformação.

A região de deformação elástica imita o comportamento de uma mola, onde a deformação aumenta linearmente com o aumento da carga e, após a retirada da carga, retorna à forma original. Mas, nos ossos não se pode considerar como comportamento de uma mola perfeita, pois, efeitos viscoelásticos durante a deformação, em função dos fluídos presentes na matriz óssea, causam perda de energia elástica, que pode ser observada quando se realiza um ensaio de carregamento e descarregamento. As curvas de carregamento e a de descarregamento não fazem o mesmo caminho, formando um ciclo fechado, o que representa um ciclo de histerese (SHIMANO; SHIMANO; VOLPON ${ }^{92}$, 2002).

Já, na região plástica, o material estará com deformações permanentes, mas em muitos casos, esta região é importante, principalmente quando a ruptura não pode ocorrer imediatamente após o limite elástico. Ou seja, o material deverá absorver mais energia antes de romper. 
A inclinação da curva carga $x$ deformação na região elástica determina a rigidez que pode ser rigidez extrínseca ou estrutural, onde os ossos possuem uma maior rigidez. Ao converter a carga em tensão e a deformação em deformação relativa, obtém-se uma curva tensão $x$ deformação relativa e a inclinação desta curva na região elástica é o módulo de elasticidade ou módulo de Young e representa a rigidez intrínseca do material (TURNER; BURR $^{101}$, 1993). Esta diferença pode ser observada ao comparar ensaios em ossos inteiros (rigidez extrínseca) com ensaios realizados em corpos de prova de osso (rigidez intrínseca).

O tecido ósseo por ser formado de materiais de diferentes naturezas (colágeno e hidroxiapatita), distribuídos de diferentes formas (lamelas ósseas, trabéculas, etc), dá aos ossos comportamentos mecânicos característicos como a viscoelasticidade, a anisotropia e a não homogeneidade.

O comportamento de um material viscoelástico pode ser considerado como sendo um conjunto dos comportamentos de um material elástico com o de um material viscoso (SEDLIN $\left.{ }^{91}, 1965\right)$. Um material com comportamento elástico ideal é caracterizado pelo armazenamento de toda energia fornecida a ele durante o processo de deformação mecânica, na forma de energia potencial elástica, e é devolvida ao retirar-se o esforço que a causou, podendo ser exemplificado pelo comportamento de uma mola. Um material com comportamento viscoso se caracteriza por ter toda a energia a ele fornecida no processo de deformação mecânica, dissipada na forma de calor, o mesmo comportamento de um amortecedor. Uma caracterização dos materiais viscoelásticos é a dependência do comportamento mecânico com a taxa de carregamento, ou seja, velocidade de aplicação de carga. BURSTEIN; WRIGHT ${ }^{24}, 1994$, fizeram testes numa série de três corpos de prova de osso cortical, sendo cada um submetido a uma velocidade diferente de aplicação da carga e confirmaram a influência da velocidade de aplicação da carga nas propriedades mecânicas dos ossos.

Materiais anisotrópicos apresentam diferentes propriedades mecânicas quando testados em diferentes direções. Ou seja, o comportamento mecânico depende diretamente da direção e do sentido da força aplicada. E os 
materiais não homogêneos são aqueles cujo comportamento mecânico varia de região em um mesmo material.

A alta concentração de colágeno da fase orgânica permite ao osso resistir a tensões de tração. $E$, a fase inorgânica dá ao osso excelente resistência às tensões de compressão (TUREK $\left.{ }^{100}, 1991\right)$.

Para o osso trabecular a definição de rigidez é mais difícil, pois ele é formado por trabéculas individuais, com rigidez própria, que formam toda a estrutura com uma única rigidez. O osso trabecular possui uma rigidez material que é a rigidez de cada trabécula e uma rigidez estrutural que é a rigidez da estrutura trabecular disposta espacialmente. A maioria dos estudos concentrase nas propriedades estruturais devido à grande dificuldade do estudo em trabéculas individuais. As propriedades estruturais variam para as diferentes regiões anatômicas, pois dependem da densidade e da orientação trabecular.

Para medir as propriedades do osso trabecular, alguns métodos foram desenvolvidos para ensaiar vértebras e o colo femoral (ANDREASSEN; MELSEN; OXLUND ${ }^{5}$, 1996, HOU et al. ${ }^{52}$, 1990). Para vértebras, uma força de compressão é aplicada ao corpo vertebral inteiro ou a uma secção do meio da vértebra, para se ter superfícies paralelas e planas. Para o colo femoral, uma força de compressão é aplicada à cabeça femoral que produz tensões de flexão e compressão.

$\mathrm{RHO}$ et al. ${ }^{84}$, 1997, realizaram um experimento investigador para mensurar as propriedades elásticas intrínsecas dos diversos componentes microestruturais do osso vertebral humano trabecular e osso cortical de tíbia pela técnica de nanoedentação. Espécimes de duas vértebras torácicas ( $\mathrm{T}-12)$ e duas tíbias foram obtidos de cadáveres humanos congelados. Após a secagem e embebição em resina epóxica, os testes de nanoedentação foram conduzidos para medir o módulo de Yong e a dureza do osso trabecular da vértebra em únicos ósteons e osso lamelar intersticial da tíbia. As mensurações do osso trabecular da vértebra foi realizado na transversal, e o módulo de Yong foi de 13,5 $\pm 2,0 \mathrm{GPa}$. Os espécimes da tíbia foram testados no sentido longitudinal e o módulo de Yong foi 22,5 \pm 1,3 GPa para os ósteon, e de 25,8 \pm 
0,7 GPa para as lamelas intersticial. A análise de variância demonstrou que a diferença na medida de módulo de elasticidade foi estatisticamente significante entre eles.

TURNER et al. ${ }^{103}$, 1999, avaliaram e compararam o módulo de elasticidade do osso humano cortical e trabecular de um mesmo doador através de duas técnicas: nanoedentação e microscopia acústica. O corpo de prova foi obtido através de um bloco $(2 \mathrm{~cm})$ do osso medular do côndilo femoral distal e uma secção $(1 \mathrm{~mm})$ do osso cortical da epífise femoral esquerda. Para a avaliação do módulo de elasticidade utilizou-se a mensuração da velocidade acústica que foi realizada através de um microscópio de varredura acústica, e através da nanoedentação, onde se realizou a dureza permanente com um identador sobre os espécimes. $O$ módulo de elasticidade do osso cortical na direção longitudinal foi $40 \%$ maior ( $p$ $<0,01)$ do que o módulo na direção transversal. O módulo de elasticidade no tecido ósseo trabecular foi ligeiramente maior que o módulo transversal do osso cortical. Os resultados encontrados foram consistentes em ambas as mensurações e sugere-se que o módulo de elasticidade do osso trabecular é maior que o osso cortical. Observou-se que em ambas as técnicas houve similaridade de resultados, assim considerando a nanoedentação como uma possibilidade de mensuração do módulo de elasticidade.

ZYSSET et al. ${ }^{114}$, 1999, quantificaram as propriedades elásticas do osso lamelar e comparou essas propriedades com as microestruturas trabecular, intersticial e ósteons da epífise e diáfise femoral humano. A técnica de nanoedentação com sistema de irrigação constante foi usada simultaneamente à mensuração da força. O módulo elástico isotrópico foi calculado através da curva de não carga, assumindo uma proporção de Poisson de 0,3, enquanto a dureza foi definida como a máxima força dividida pela área de contato. O módulo elástico variou entre $6,9 \pm 4,3 \mathrm{GPa}$ no tecido trabecular da cabeça do fêmur de humano feminino de 74 anos e 25,0 \pm 4,3 GPa no tecido intersticial da córtex da diáfise humano feminino de 69 anos, $A$ média do módulo de elasticidade encontrada foi significantemente influenciada pelo tipo lamelar e pelo doador. A interação entre o tipo lamelar e o doador foi 
altamente significante $\left(\mathrm{p}<10^{-6}\right)$. A dureza seguiu uma similar distribuição como o módulo de elasticidade, mas com baixo contraste estatístico. Concluiu-se que a nanoestrutura do tecido ósseo deve diferir substancialmente pelo tipo lamelar, sítio anatômico e indivíduos, sugerindo que a heterogeneidade tecidual é um potencial importante na fragilidade óssea e adaptação.

VAN RIETBERGEN et al. ${ }^{108}$, 1995, determinaram um novo método de avaliação das propriedades elásticas através de um modelo de elemento finito. O tamanho do espécime e a possibilidade do efeito são fatores complicadores quando se usa métodos tradicionais de testes mecânicos. Um cubo de $5 \mathrm{~mm}$ de osso trabecular foi utilizado neste método de avaliação tridimensional, constituindo um modelo com 296.679 elementos. O resultado encontrado no trabalho foi de 2,23 GPa, enquando que na literatura observa-se um valor de módulo de elasticidade de 10,1 GPa. Conclui-se que o modo de deformação da trabécula no presente cubo foi predominantemente na compressão. De acordo com os autores o novo método ofereceu uma nova perspectiva do estudo do osso trabecular.

BECK et al. ${ }^{10}$, 1997, avaliaram o osso trabecular por um método tridimensional desenvolvido no trabalho cuja resolução é independente do tamanho do espécime. Finas camadas foram serialmente removidas de um espécime usando uma máquina computadorizada controlada numericamente milimetrada (CNC), e cada secção foi exposta a uma imagem usando uma câmera digital de baixa magnificação. Espécimes espessos foram digitalizados sem a perda de resolução pelo movimento do espécime sobre a câmera. As imagens de cada campo foram facilmente registradas, secções de alto contraste foram impregnadas pela coloração preta do osso com nitrato de prata e embebidas em metilmetacrilato branco. A principal limitação desta técnica foi que os espécimes foram destruídos e o processo foi relativamente lento, mas devido a sua precisão, independentemente da resolução da imagem, do tamanho do espécime pode ser de fácil implantação, esta nova técnica é um excelente método para determinar a arquitetura do osso trabecular, particularmente quando a alta resolução é requerida. 
RHO; PHARR ${ }^{85}$, 1999, avaliaram propriedades mecânicas do osso após a secagem através do método de nanoedentação. Os testes foram conduzidos para medir o modulo elástico e dureza de dois espécimes cortical de seção transversal obtidos das áreas adjacentes do fêmur de bovinos. Um espécime foi seco completamente no ar antes de ser testado enquanto o outro foi armazenado em água deionizada. As propriedades dos ósteons e das lamelas intersticiais mostraram diferença estatisticamente significante $(p<0,0001)$. Nos espécimes que sofreram a secagem observou-se um aumento do módulo de elasticidade de 9,7\% para as lamelas intersticiais e de 15,4\% para os ósteons. Em relação à dureza houve um aumento de 12,2\% para a lamela intersticial e 17,6\% para os ósteons.

VAN DER LINDEN et al. ${ }^{106}$, 2001, investigaram o efeito das diferentes distribuições minerais através de um modelo de elemento finito 3D do osso trabecular humano e calcularam a rigidez aparente destes modelos. Quando o modelo linear foi usado a distribuição mineral mudou ligeiramente a rigidez aparente, variando entre uma diminuição de $8 \%$ e um aumento de 4\% comparados ao modelo uniforme. O modelo exponencial resultou na rigidez aparente aumentada até $20 \%$ no sentido do longo eixo principal. Uma fina camada mineralizada $(28 \mu \mathrm{m})$ e o osso altamente mineralizado resultaram na rigidez mais elevada e isto leva à reduções do risco da fratura. A distribuição mineral não uniforme nas trabéculas afeta as propriedades mecânicas do osso esponjoso e a rigidez do tecido, usando um modelo FE, poderia ser melhorada incluindo a informação detalhada sobre a distribuição mineral dos modelos trabeculares.

Embora os estudos recentes do nanoindentação revelem a existência de variações substanciais no módulo de elasticidades, pouco é sabido a respeito dos efeitos biomecânicos de tais variações intra-espécimes. JAASMA et al. ${ }^{56}, 2002$, utilizaram o modelo de elemento finito para investigar estes efeitos. Com informação de literatura limitada na distribuição espacial de intra-espécimes das variações no módulo tecidual, duas distribuições espaciais plausíveis foram avaliadas. Além disso, três espécimes (pescoço femoral humano, corpo vertebral humano, e tíbia proximal de bovinos) foram estudados 
para avaliar o papel da arquitetura trabecular. Os resultados indicaram que para todas as combinações do espécime/distribuição, o módulo aparente do espécime inteiro diminui não linearmente com coeficiente de variação crescente (COV) do módulo do tecido dentro do espécime. O módulo aparente diminuiu $4 \%$ enquanto que o módulo COV do tecido foi aumentado de $0 \%$ a $20 \%$ mas diminuiu por 7-24\%, dependendo da suposta distribuição espacial, para um aumento no módulo COV do tecido de $20 \%$ a $50 \%$. Para o carregamento compressivo ao limite elástico, o módulo crescente COV do tecido de $20 \%$ a $50 \%$ causou até um aumento de 28 dobras na quantidade de tecido falhado, dependendo da distribuição espacial suposta e da arquitetura trabecular. As variações intra-espécimes no modulo tecidual, se grandes, podem ter efeitos apreciáveis na falha aparente trabecular do módulo.

FAN et al. ${ }^{36}$, 2002, investigaram os efeitos da anisotropia elástica através de medidas por nanoindentação no osso cortical tibial humano. A nanoindentação foi conduzida em 12 sentidos diferentes em três planos principais para os ósteons e lamelas intersticiais. $O$ módulo experimental do recorte foi encontrado para variar com sentido do recorte e mostrou a anisotropia óbvia (análise de sentido único do teste da variação, $P<0,0001$ ), porque os módulos experimentais do recorte em um sentido específico é determinado por todas as constantes elásticas do osso cortical, um modelo teórico complexo é requerido para analisar os resultados experimentais. Uma análise recentemente desenvolvida do recorte para as propriedades de materiais anisotrópicos foi usada para quantificar o módulo do recorte usando a matriz da rigidez do osso cortical tibial humano, que foi obtido dos estudos precedentes de ultra-som. Após permitir os efeitos da preparação de espécime (os espécimes desidratados na nanoindentação testados contra espécimes úmidos em testes de ultra-som) e as propriedades estruturais do osso (micro componentes diferentes com propriedades mecânicas diferentes), não houve nenhuma diferença estatística significativa entre o módulo experimental do recorte corrigido e o módulo do recorte correspondente (t-teste não pareado, $\mathrm{P}$ $>0,5)$. A variação do módulo do recorte correspondente que foi encontrada exibiu as mesmas tendências que os dados do módulo experimental do recorte 
corrigido. Estes resultados mostram que os efeitos da anisotropia em medidas por nanoindentação podem ser avaliados quantitativamente.

Habilidade de determinar propriedades elásticas trabeculares e da falha do tecido do osso tem importância biológica e clínica. BAYRAKTAR et al. $^{9}, 2004$, tiveram como hipótese que as propriedades elásticas, tensão e compressão do tecido trabecular são similares àquelas do tecido cortical. A eficácia do módulo tecidual e a deformação tecidual foram calibradas para os espécimes femoral humanos de cadáveres feitos em 11 doadores, usando uma combinação de teste mecânico do nível aparente e espécime-específico, alta resolução, modelo de elemento finito não linear. As propriedades trabecular do tecido foram comparadas então ao módulo elástico medido e à tensão dos espécimes de osso cortical de fêmures humanos obtidos de 34 doadores similares. As propriedades do osso cortical obtidas e os efeitos da porosidade vascular foram estatìsticamente eliminados. Os resultados indicaram que 0 modulo elástico foi de $10 \%$ mais baixo $(p<0,05)$ para o tecido trabecular $(18,0 \pm$ 2,8 GPa) do que para o tecido cortical (19.9 $\pm 1.8 \mathrm{GPa})$. A força tensãocompressão da força assimétrica para o tecido trabecular, 0,62 na média, foi similar aos valores relatados na literatura para o osso cortical. As tensões elásticas do módulo e da tensão para o tecido trabecular foram ligeiramente mais baixas do que aquelas do tecido cortical; por causa do efeito acumulativo destas diferenças, a força do tecido é aproximadamente $25 \%$ maior para o osso cortical. 


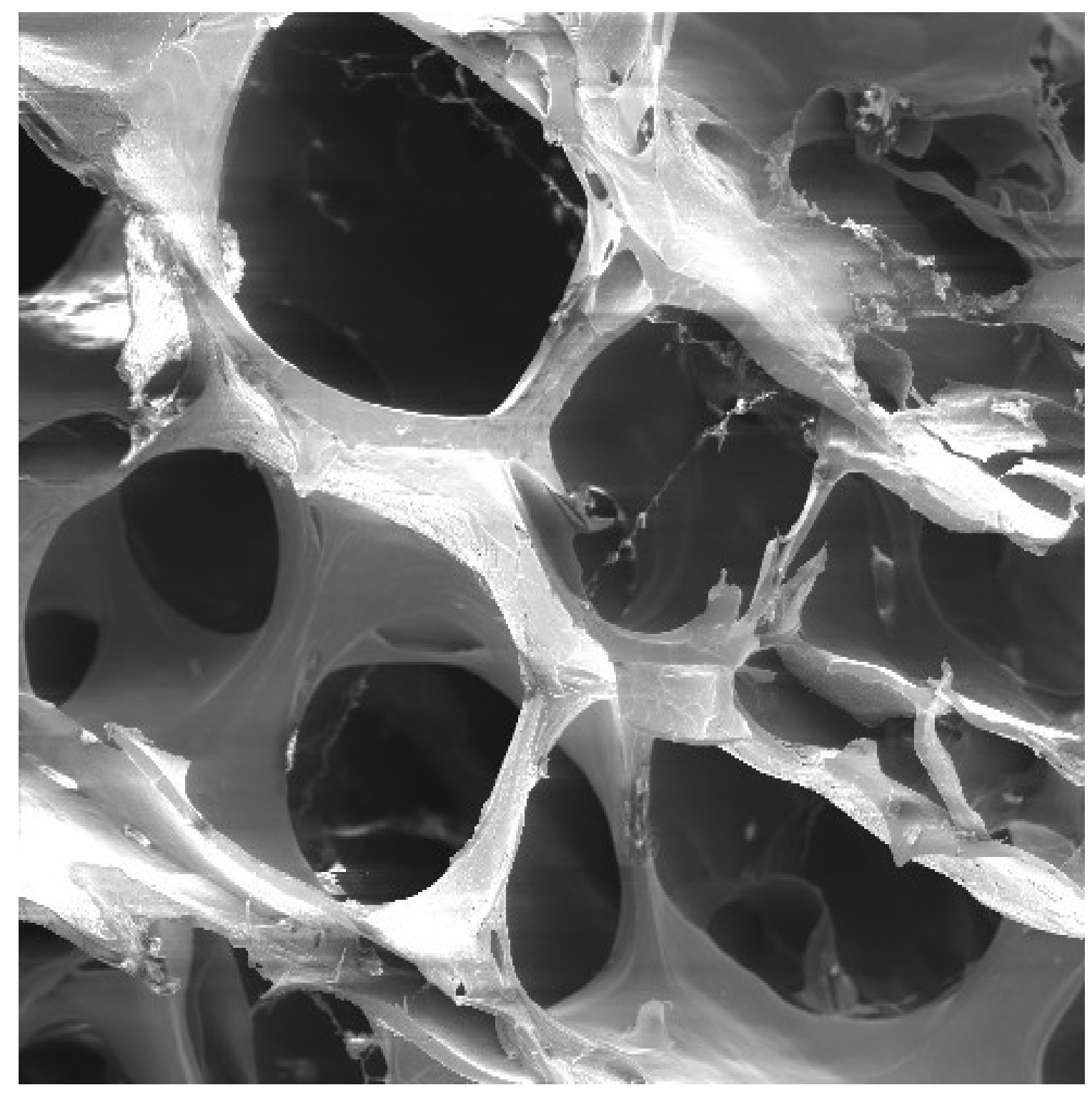

\section{3 - PROPOSIÇÃO}

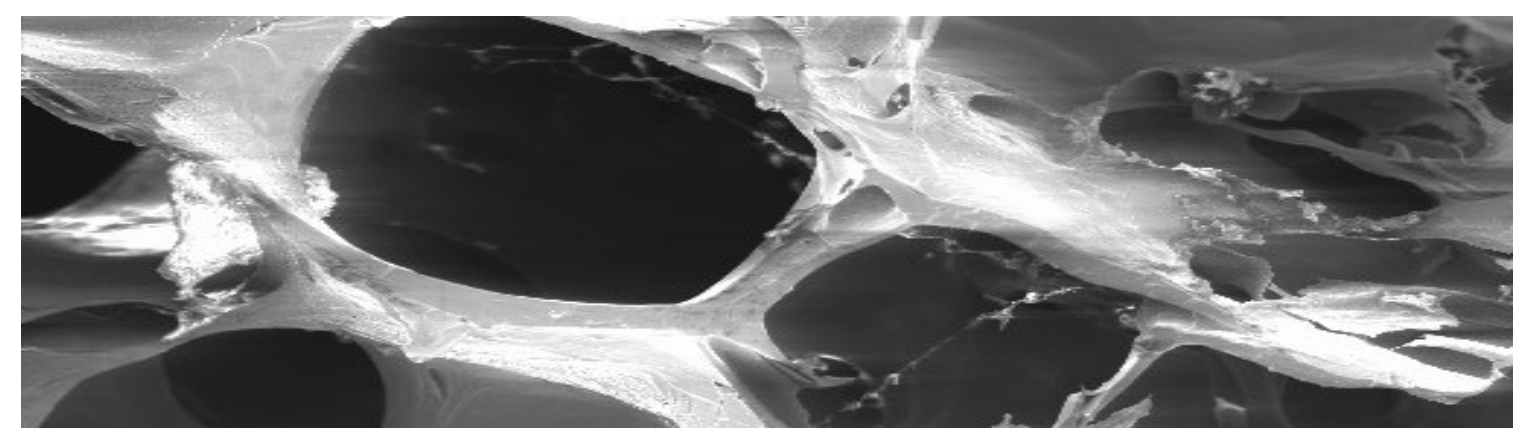




\section{PROPOSIÇÃO}

\subsection{OBJETIVO GERAL}

$\rightarrow$ Determinar a resistência do osso mineralizado e desmineralizado,

$\rightarrow$ Determinar o módulo de elasticidade do osso mineralizado e desmineralizado,

\subsection{OBJETIVO ESPECÍFICO}

$\rightarrow$ Hipótese Nula:

- Não haverá diferença nas propriedades mecânicas de resistência a tração e módulo de elasticidade entre o osso desmineralizado e mineralizado. 


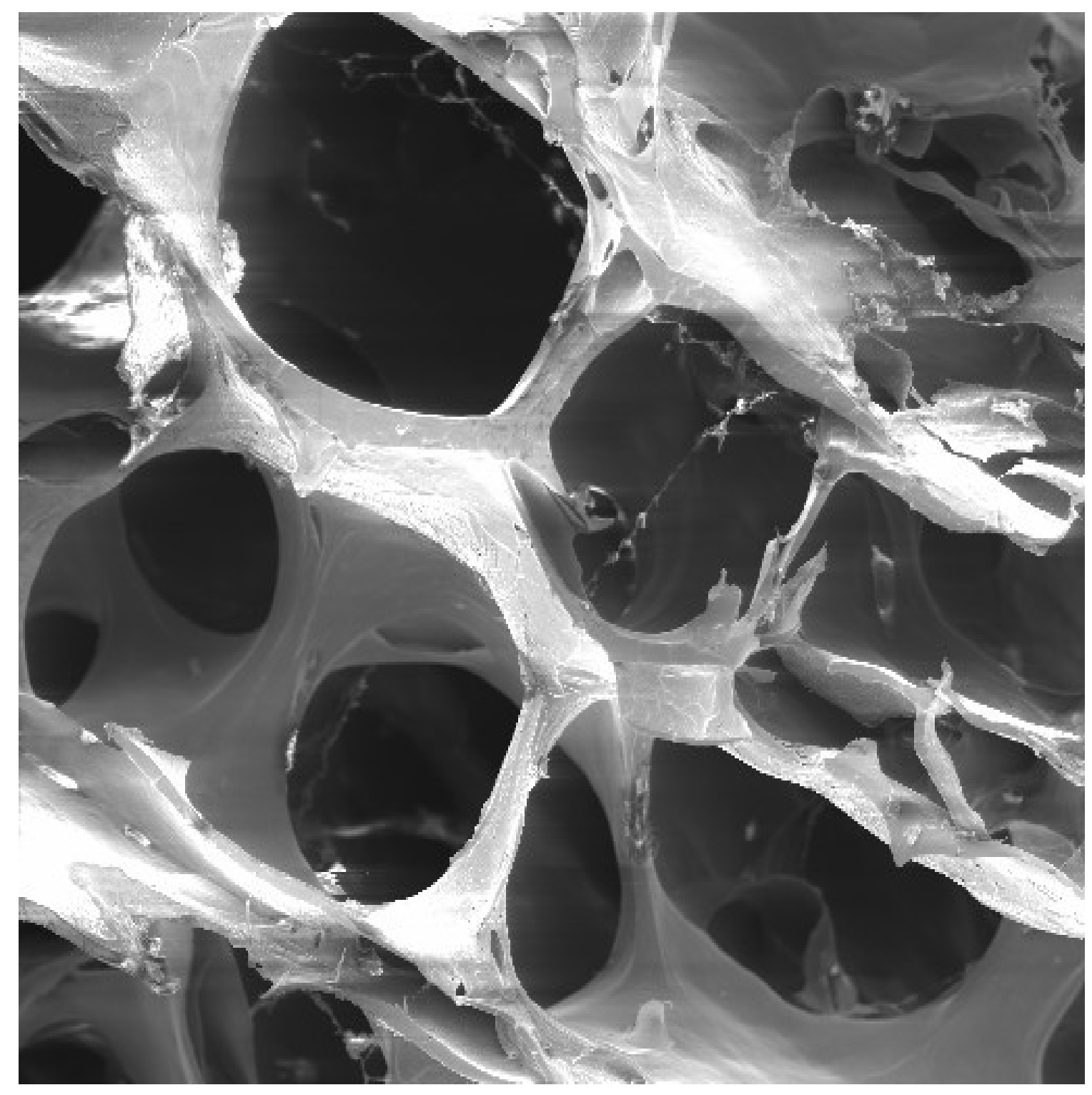

\section{4 - MATERIAIS E MÉTODOS}

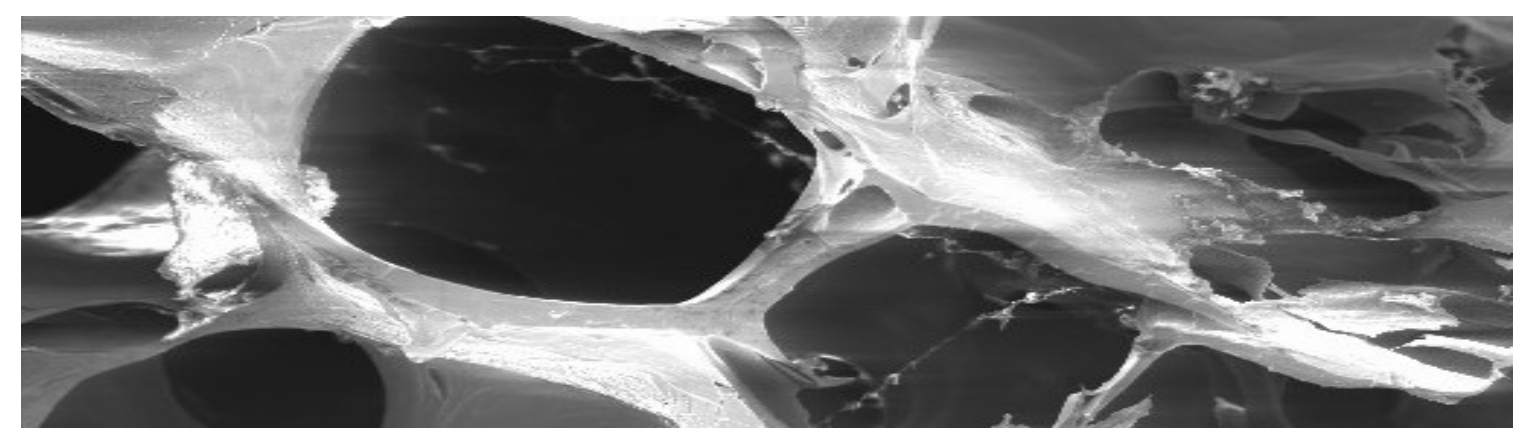




\section{MATERIAIS E MÉTODO}

\subsection{ANIMAIS}

Para este trabalho, foram utilizados 24 ratos albinos da linhagem Wistar (Rattus norvegicus), machos adultos, com aproximadamente 250 a $300 \mathrm{~g}$, fornecidos pelo biotério central da Faculdade de Odontologia de Bauru (Fig. 2), que durante todo o período experimental, receberam dieta normal "ad libitum" composta de ração e água. Desde o nascimento, os animais foram agrupados aleatoriamente em 5 caixas ( 4 caixas continham 5 animais e 1 caixa tinha somente 4 animais) com forragem de maravalhas, substituídas regularmente e, após um período de 5 meses de vida (idade adulta), foram sacrificados através de superdosagem anestésica.

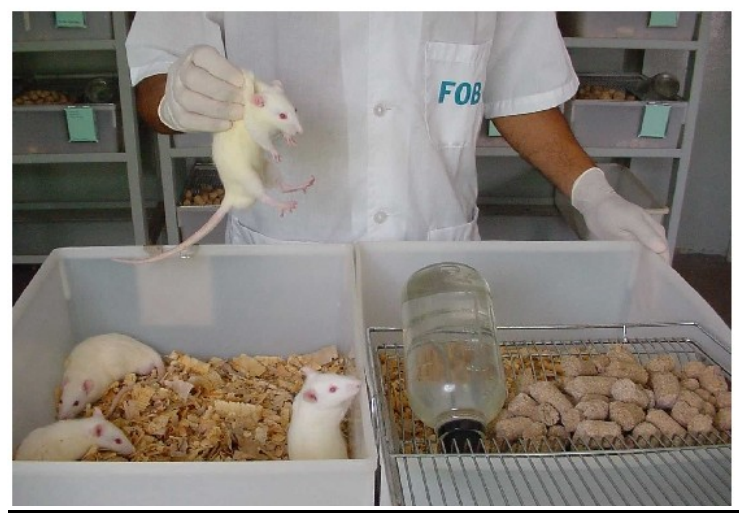

Figura 2 - Ratos albinos da linhagem Wistar (Rattus norvegicus) do Biotério Central da Faculdade de Odontologia de Bauru - USP.

Os vinte quatro animais foram divididos em dois grupos, com 12 animais cada, sendo os grupos determinados através do teste a ser realizado (Microtração ou Módulo de elasticidade). Sabe-se que a calvária dos ratos possui anatomicamente duas parietais (Fig.3) que possibilita a duplicação dos grupos e assim viabilizando a confecção de sub-grupos (mineralizado e desmineralizado), ou seja com os vinte quatro animais houve a possibilidade de confecção de 48 espécimes alocados em 2 grupos com seus respectivos subgrupos (Fig. 4). 


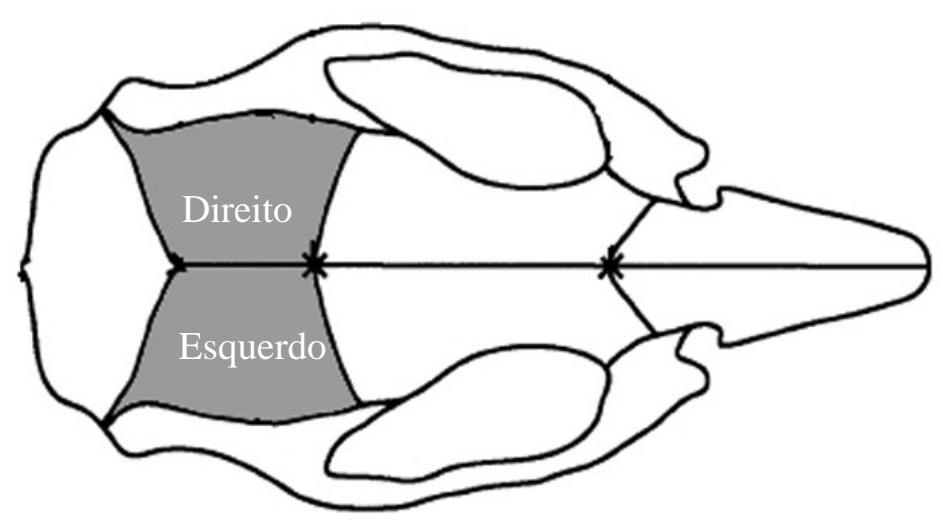

Figura 3 - Esquema da calvária de ratos. A área em destaque refere-se às duas parietais do animal

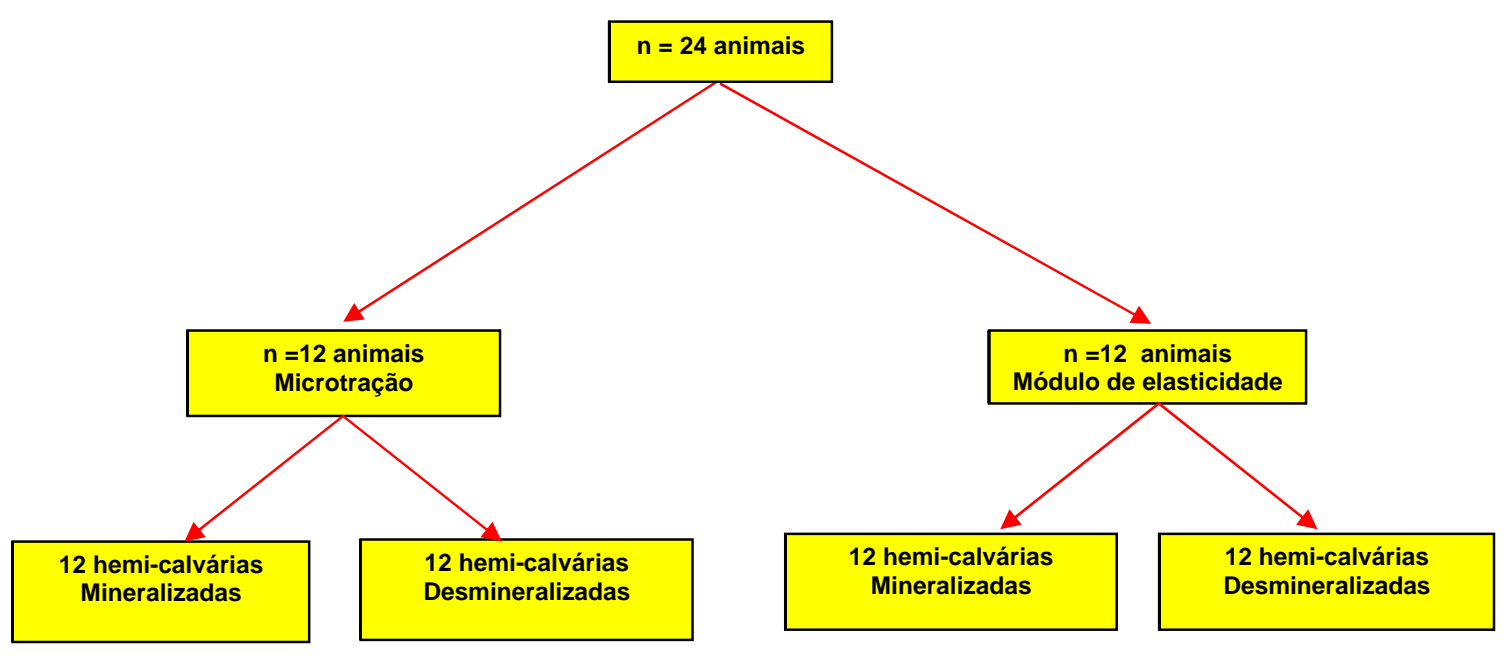

Figura 4 - Esquema das divisões dos grupos e sub-grupos.

\subsection{SACRIFÍCIO DOS ANIMAIS}

Para o sacrifico dos animais foi utilizado o protocolo do biotério central da Faculdade de Odontologia de Bauru - USP. Todos os animais dos grupos apresentados foram mortos por superdosagem de anestésico e relaxante muscular aplicado diretamente no coração do animal (Fig.5).

As drogas utilizadas para tal procedimento foram:

$\rightarrow$ Anasedan $^{\circledR}$ (SESPO - Divisão vetbrands saúde animal, Jacareí, São Paulo, Brasil): principio ativo é a Xilazina (Cloridrato de Xilazina), 
considerado como um anestésico e sedativo, e se apresenta na forma de frasco contendo $10 \mathrm{~mL}$.

$\rightarrow$ Dopalen $^{\circledR}$ (SESPO - Divisão vetbrands saúde animal, Jacareí, São Paulo, Brasil): principio ativo é a Quetamina (Cloridrato de ketamina), considerado como um anestésico e sedativo, e se apresenta na forma de frasco contendo $10 \mathrm{~mL}$.

Para determinar a quantidade de substância a ser utilizada neste procedimento realizou-se um projeto piloto com 4 animais, concluindo-se que poderíamos utilizar $0,8 \mathrm{~mL}$ de solução $\left(0,4 \mathrm{~mL}\right.$ de Dopalen ${ }^{\circledR}$ e $0,4 \mathrm{~mL}$ de Anasedan ${ }^{\circledR}$ ), quando injetada diretamente no coração do animal.

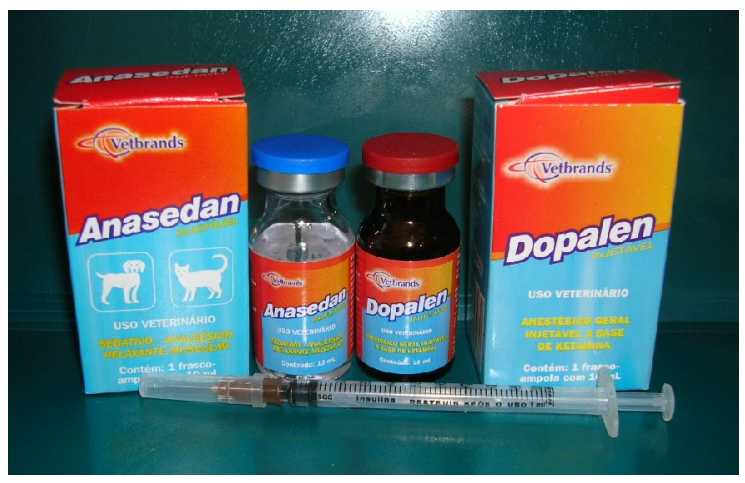

Figura 5 - Drogas utilizadas no procedimento de sacrifício dos animais, Dopalen ${ }^{\circledR} \mathrm{e}$ Anasedan ${ }^{\circledR}$ (SESPO - Divisão vetbrands saúde animal, Jacareí, São Paulo, Brasil).

Após o sacrifício dos animais realizou-se a tricotomia da região da calota craniana dos animais com auxílio de uma lâmina de barbear, para melhor visualização da área a ser removida (as duas parietais).

Com auxílio de uma serra de corte para ossos do Departamento de Anatomia da Faculdade de Odontologia de Bauru realizou-se a remoção da calvária por inteira do animal. 


\subsection{GRUPO MINERALIZADO}

\subsubsection{PREPARO DA PEÇA PARA TESTE DE MICROTRAÇÃO}

Após a coleta das calvárias, as peças foram dissecadas e cortadas com discos de aço em baixa rotação sob constante irrigação, deixando o espécime com as dimensões de 10 - 12 mm de comprimento, 3 - $4 \mathrm{~mm}$ de largura e $1 \mathrm{~mm}$ de espessura, (Fig. 6) observando-se sempre a área das parietais. Após este procedimento, os espécimes foram armazenados em água deionizada a $37^{\circ} \mathrm{C}$, até a realização do teste.

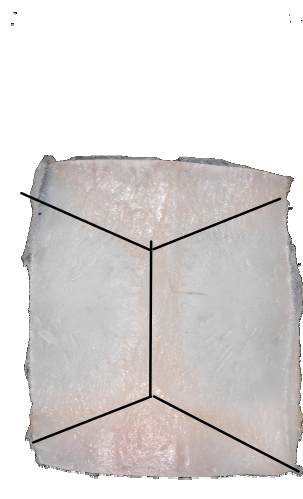

$\mathrm{a}$
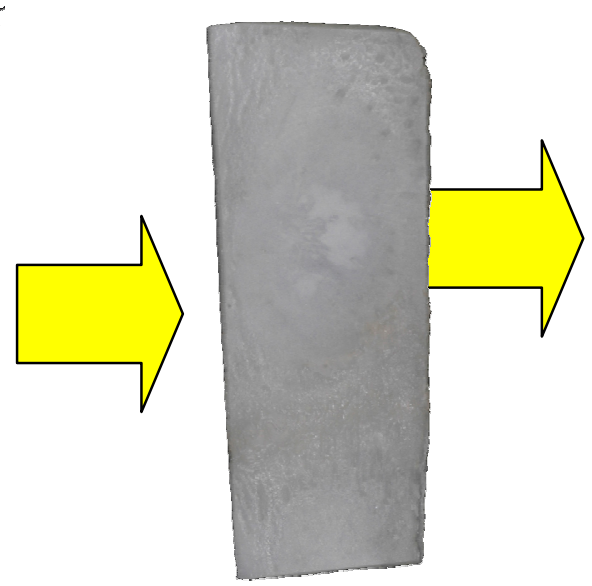

b

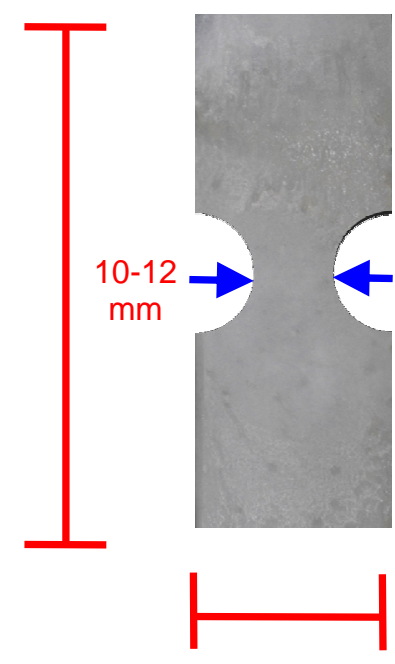

3-4 $\mathrm{mm}$

Figura 6 - Esquema para o preparo do espécime. a) calota craniana após a dissecação pronto para o preparo do corpo de prova. b) Corpo de prova divido ao meio para confecção do espécime. c) padronizado nas dimensões adequadas para teste mecânico $(10 \times 3 \mathrm{~mm})$, seta azul demonstrando a região que foi utilizada para mensuração da secção transversal (largura). 


\subsubsection{TESTE DE MICROTRAÇÃO}

Para a realização do teste de microtração utilizou-se uma máquina de tração Universal de teste Virtodyne, modelo V1000 (Liveco Inc., Burlington, VT) (Fig. 7) que possibilita a fixação dos espécimes na própria máquina.

Os espécimes foram fixados na máquina com auxílio de um adesivo à base de cianocrilato (SANO et al. ${ }^{89}$, 1995) e submetidos ao ensaio de tração a uma velocidade de $1 \mathrm{~mm} / \mathrm{min}$.

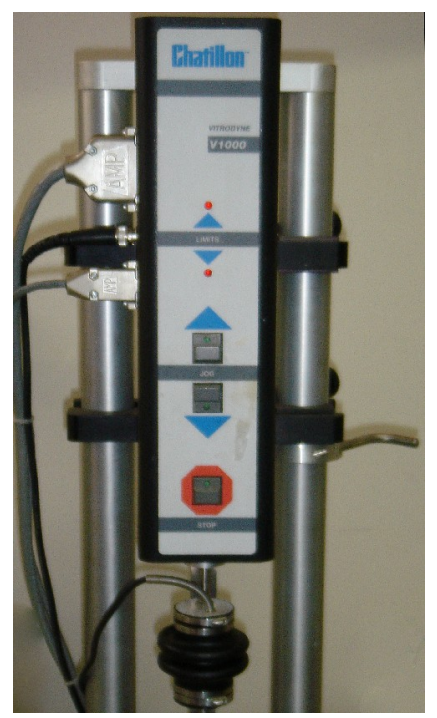

Figura 7 - Máquina de ensaio Vitrodyne, modelo V1000 (Liveco Inc., Burlington, VT).

Após a realização da tração, a máquina revela o valor de tensão máxima gerada para a fratura/rompimento do espécime, sendo o valor projetado em Quilograma $(\mathrm{Kg})$, dividido pela área de secção transversal $\left(\mathrm{cm}^{2}\right)$, que é obtida pela mensuração da largura $x$ a espessura da área central do espécime (Fig.4c, ver seta azul) e multiplicado por uma constante universal $(0,0981)$ chegando ao valor de tensão máxima em MegaPaschal (MPa):

$$
\text { Tensão }=\frac{\text { Tração }(\mathrm{Kg}) \times 0,0981}{\text { Área }\left(\mathrm{cm}^{2}\right)}=\mathrm{MPa}
$$




\subsubsection{PREPARO DA PEÇA PARA TESTE DE MÓDULO DE ELASTICIDADE}

Após a coleta das calvárias, as peças foram dissecadas e cortadas com discos de aço em baixa rotação sob constante irrigação, deixando o espécime com as dimensões de 10 - 12 mm de comprimento, 3 - $4 \mathrm{~mm}$ de largura e $1 \mathrm{~mm}$ de espessura, (Fig. 8). Realizou-se um corte de padronização na área central do corpo de prova para diminuir a área a ser testada, diminuindo a carga da máquina de ensaio. Após este procedimento, os espécimes permaneceram armazenados em água deionizada a $37^{\circ} \mathrm{C}$, até a realização do teste.

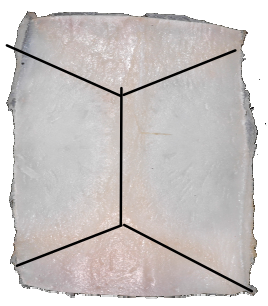

a

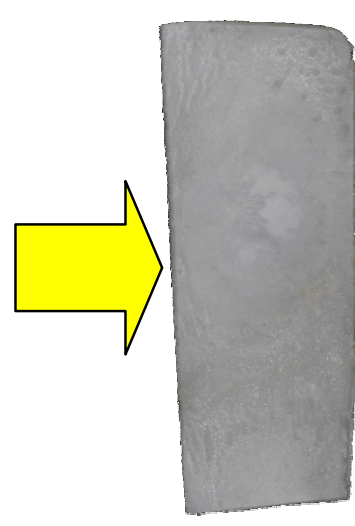

b

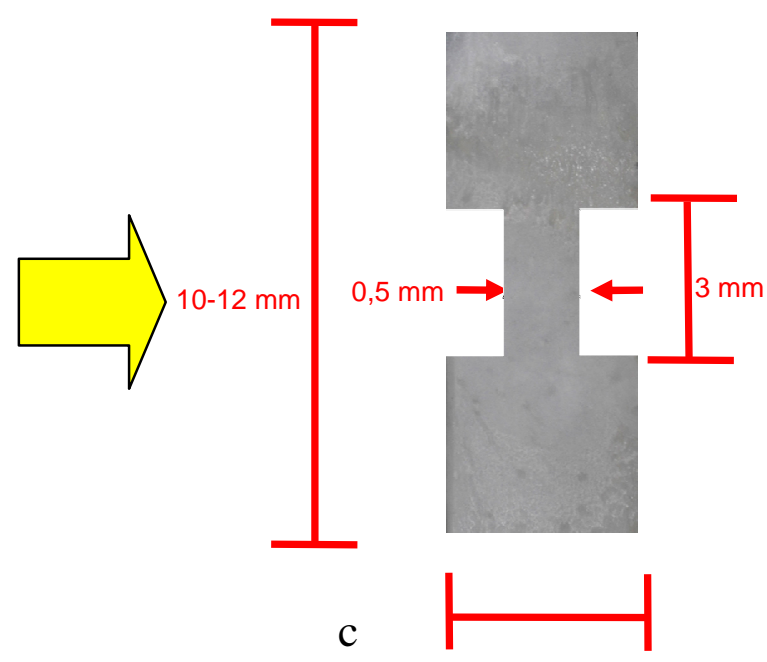

3-4 $\mathrm{mm}$

Figura 8 - Esquema para o preparo do espécime. a) calota craniana após a dissecação pronto para o preparo do corpo de prova. b) Corpo de prova divido ao meio para confecção do espécime. c) padronizado nas dimensões adequadas para teste mecânico $(10 \times 3 \mathrm{~mm})$. 


\subsubsection{TESTE DE MÓDULO DE ELASTICIDADE}

Para a realização do teste de módulo de elasticidade utilizou-se a mesma máquina de tração Universal de teste Virtodyne, modelo V1000 (Liveco Inc., Burlington, VT) (Fig. 7) que possibilita a fixação dos espécimes na própria máquina.

Os espécimes foram fixados com auxílio de um adesivo à base de cioanocrilato (SANO et al. ${ }^{89}$, 1995) e submetidos ao ensaio de tração a uma velocidade de $1,00 \mathrm{~mm} / \mathrm{min}$.

Observa-se que o teste realizado para determinar o módulo de elasticidade foi o mesmo de tração, isso se dá porque a máquina Vitrodyne fornece o quanto o espécime se deslocou até a sua fratura, juntamente com a tensão máxima gerada, possibilitando assim o cálculo do módulo de elasticidade através da seguinte formula:

$$
\begin{aligned}
& E=\frac{T(M P a)}{d(\%)} \\
& E=\text { Módulo de Elasticidade (MPa) } \\
& T=\text { Tensão (MPa) } \\
& d=\text { deformação (\%) } \\
& d=\frac{\Delta L}{L i} \quad(\mathrm{Lf}-\mathrm{Li}) \times 100 \\
& \mathrm{~d}=\text { deformação (\%) } \\
& \Delta \mathrm{L}=\text { Variação do comprimento } \\
& \mathrm{Li}=\text { Tamanho inicial } \\
& \mathrm{Lf}=\text { Tamanho final }
\end{aligned}
$$


Um dos motivos do espécime ser na forma de ângulos vivos (enquanto o de tração á arredondado) é que há possibilidade de medirmos o tamanho inicial e consequentemente acharmos o quanto deslocou (tamanho final) (Fig.9).

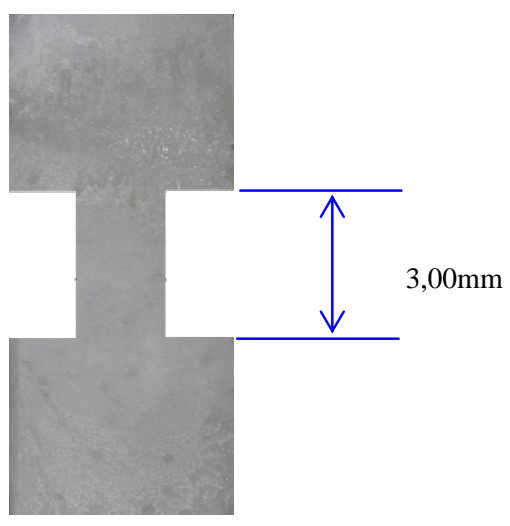

Figura 9 - Desenho do espécime para o teste de módulo de elasticidade. Observar os ângulos vivos criados para conseguir determinar o tamanho inicial da região do espécime que sofrerá a tensão.

\subsection{GRUPO DESMINERALIZADO}

\subsubsection{PREPARO DA PEÇA PARA TESTE DE MÓDULO DE ELASTICIDADE E MICROTRAÇÃO}

Os espécimes foram cortados como descrito anteriormente, a única modificação é que neste caso os espécimes sofreram o processo de desmineralização.

Antes da realização do procedimento de desmineralização os corpos-de-prova foram protegidos na suas extremidades com uma base de unha (Colorama, L'Oréal) para proteção contra o agente desmineraliazante (Fig. 10), pois estas extremidades serão fixadas através de presilhas na máquina de tração.

Após a pintura das extremidades, os espécimes foram submersos em uma solução de EDTA de concentração de 0,5M, por tempo indeterminado. Para a avaliação da completa desmineralização foram realizadas tomadas 
radiográficas, que possibilitaram a visualização da presença ou não de restos de minerais.

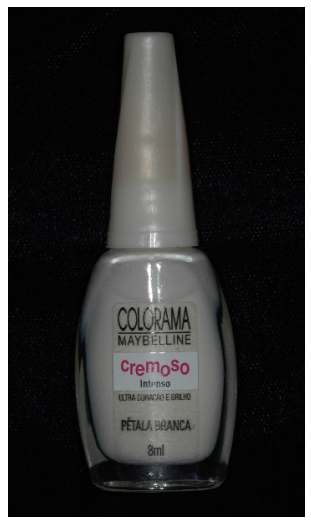

Figura 10 - Esmalte de unha para proteção da desmineralização pelo EDTA 0,5M das extremidades do espécime.

\subsubsection{TESTE DE MICROTRAÇÃO E MÓDULO DE ELASTICIDADE}

Os testes de microtração e módulo de elasticidade foram realizados pela mesma máquina de ensaio descrita anteriormente, sendo que a única modificação foi a necessidade de submersão dos espécimes durante a realização do teste, seja de microtração ou de módulo de elasticidade (Fig. 11), pois há necessidade da hidratação dos espécimes durante o teste. A solução utilizada no nosso experimento foi a água destilada.

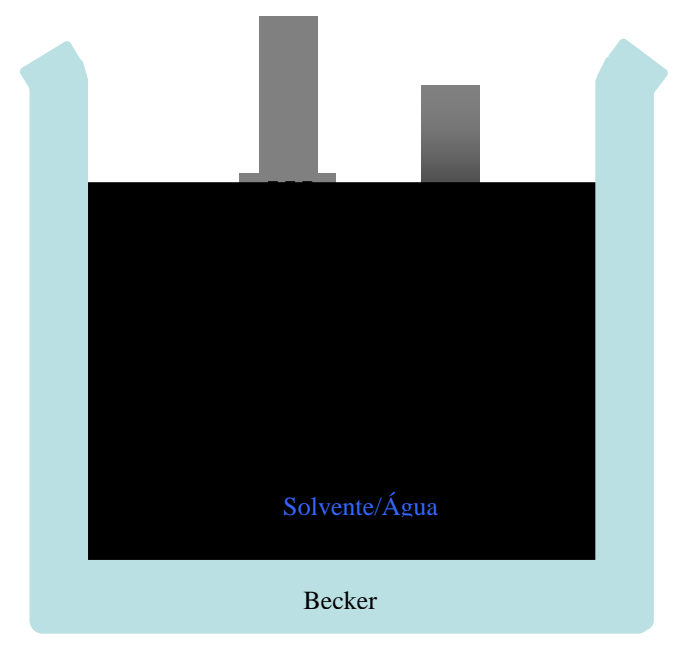

Figura 11 - Esquema do teste de módulo de elasticidade sob imersão de solução aquosa. 


\subsection{ANÁLISE ESTATÍSTICA}

Após os testes de microtração e módulo de elasticidade foram calculados as médias e desvios padrão de cada grupo, na qual foi utilizada uma análise descritiva e em seguida foi realizado o teste T de Student entre os grupos mineralizado e desmineralizado, tanto para os valores de resistência quanto ao módulo de elasticidade.

O programa utilizado para a análise estatística foi o SigmaStat 3,1 (Systat Software Inc., Richmond, California, USA). 


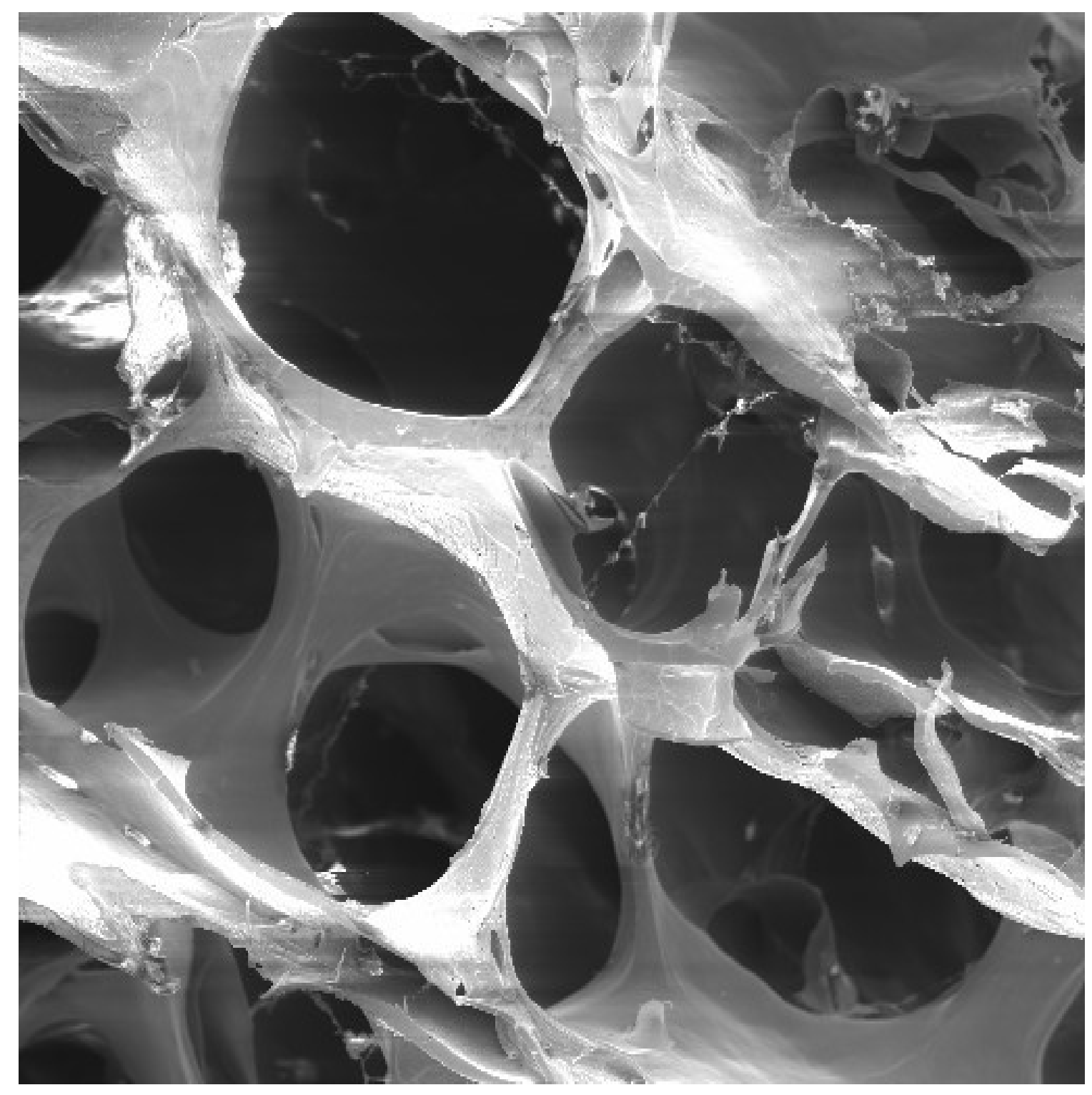

\section{5 - RESULTADOS}

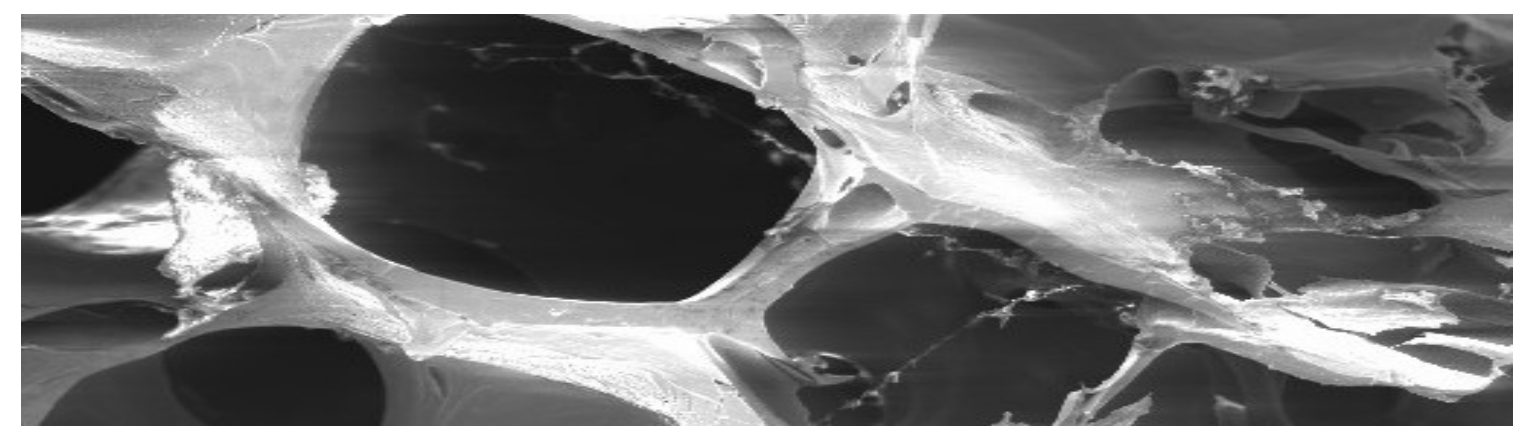




\section{RESULTADOS}

\subsection{MICROTRAÇÃO}

Os valores individuais, desvio padrão e as médias da resistência à tração do sub-grupo mineralizado se encontram na Tabela 1 e do sub-grupo desmineralizado na Tabela 2. A avaliação dos dados pelo programa estatístico SigmaStat 3.1, demonstrando o teste $\mathrm{T}$ de Student para comparação entre os sub-grupos (mineralizado e desmineralizado) está representada pela figura 12 , que foi extraído direto do programa SgimaStat 3.1. Na figura 13 há uma melhor visualização dos resultados com as médias e desvio padrão dos grupos através do gráfico. 
Tabela 1 - Valores individuas para cada espécime do sub-grupo mineralizado frente ao teste de microtração, ilustrando a área da secção transversal $\left(\mathrm{cm}^{2}\right)$, tensão máxima $(\mathrm{KgF})$, tensão máxima sobre a área $\left(\mathrm{KgF} / \mathrm{cm}^{2}\right) \mathrm{e}$ tensão (MPa).

\begin{tabular}{|c|c|c|c|c|}
\hline Espécime & Área $\left(\mathrm{cm}^{2}\right)$ & $\mathrm{KgF}$ & $\mathrm{KgF} / \mathrm{cm}^{2}$ & Tensão (MPa) \\
\hline 1 & 0,00492 & 5,345 & 1086,48 & 106,57 \\
\hline 2 & 0,005863 & 7,345 & 1252,77 & 122,9 \\
\hline 3 & 0,006256 & 7,615 & 1817,83 & 178,32 \\
\hline 4 & 0,009515 & 5,08 & 1125,14 & 110,38 \\
\hline 5 & 0,006624 & 7,415 & 1807,33 & 177,3 \\
\hline 6 & 0,003627 & 4,44 & 1224,15 & 120,09 \\
\hline 7 & 0,005781 & 7,585 & 1312,05 & 128,71 \\
\hline 8 & 0,00685 & 7,845 & 1145,25 & 112,35 \\
\hline 9 & 0,00351 & 4,66 & 1327,63 & 130,24 \\
\hline 10 & 0,009145 & 7,83 & 856,2 & 83,99 \\
\hline 11 & 0,003588 & 7,07 & 1970,45 & 193,3 \\
\hline 12 & 0,006439 & 6,145 & 954,34 & 93,62 \\
\hline Desvio Padrão & 0,001965 & 1,313 & 355,9833 & 34,9217 \\
\hline Média & 0,006009 & 6,531 & 1323,302 & 129,814 \\
\hline
\end{tabular}


Tabela 2 - Valores individuas para cada espécime do sub-grupo desmineralizado frente ao teste de microtração, ilustrando a área da secção transversal $\left(\mathrm{cm}^{2}\right)$, tensão máxima $(\mathrm{KgF})$, tensão máxima sobre a área $\left(\mathrm{KgF} / \mathrm{cm}^{2}\right)$ e tensão (MPa).

\begin{tabular}{|c|c|c|c|c|}
\hline Espécime & Área $\left(\mathrm{cm}^{2}\right)$ & $\mathrm{KgF}$ & $\mathrm{KgF} / \mathrm{cm}^{2}$ & Tensão (MPa) \\
\hline 1 & 0,005565 & 0,990 & 177,89757 & 17,45 \\
\hline 2 & 0,004725 & 0,670 & 141,79894 & 13,91 \\
\hline 3 & 0,004920 & 0,980 & 199,18699 & 19,54 \\
\hline 4 & 0,006370 & 1,745 & 273,94034 & 26,87 \\
\hline 5 & 0,00500 & 0,760 & 152,00000 & 14,91 \\
\hline 6 & 0,003240 & 0,660 & 213,70370 & 19,98 \\
\hline 7 & 0,005986 & 0,700 & 116,93952 & 11,47 \\
\hline 8 & 0,005490 & 1,145 & 208,56102 & 20,45 \\
\hline 9 & 0,005502 & 0,945 & 171,75572 & 16,84 \\
\hline 10 & 0,003920 & 0,940 & 239,79591 & 23,52 \\
\hline 11 & 0,006050 & 1,195 & 197,52066 & 19,37 \\
\hline 12 & 0,005460 & 1,105 & 202,38095 & 19,85 \\
\hline Desvio Padrão & 0,000899 & 0,301821 & 42,9489 & 3,682 \\
\hline Média & 0,00518 & 0,98625 & 191,29011 & 18,547 \\
\hline
\end{tabular}




\begin{tabular}{|c|c|c|c|c|}
\hline \multicolumn{2}{|c|}{ Teste de normalidade: } & Passou & \multicolumn{2}{|l|}{$(P=0.089)$} \\
\hline Sub-grupos & $\mathrm{N}$ & Ausentes & & \\
\hline Mineralizado & 12 & 0 & & \\
\hline Desmineralizado & 12 & 0 & & \\
\hline Sub-grupos & & Médias & DesvioPadrão & SEM \\
\hline Mineralizado & & 129.814 & 34.922 & 10.081 \\
\hline Desmineralizado & & 18.547 & 3.682 & 1.063 \\
\hline Diferença & & 111.267 & 35.715 & 10.310 \\
\hline \multicolumn{5}{|c|}{$\begin{array}{l}\rightarrow \text { Intervalo de confiabilidade de } 95 \% \text { para as diferenças das médias: } 88.574 \\
\text { a } 133.959\end{array}$} \\
\hline$\rightarrow$ Não houve dife & ença & estatisticam & nte significante $(P=<$ & \\
\hline
\end{tabular}

Figura 12 - Análise estatística pelo programa SigmaStat 3,1. Teste T de Student avaliando as Médias, Desvio Padrão, Grau de Liberdade, Intervalo de Confiabilidade e Diferença Estatísicas. 


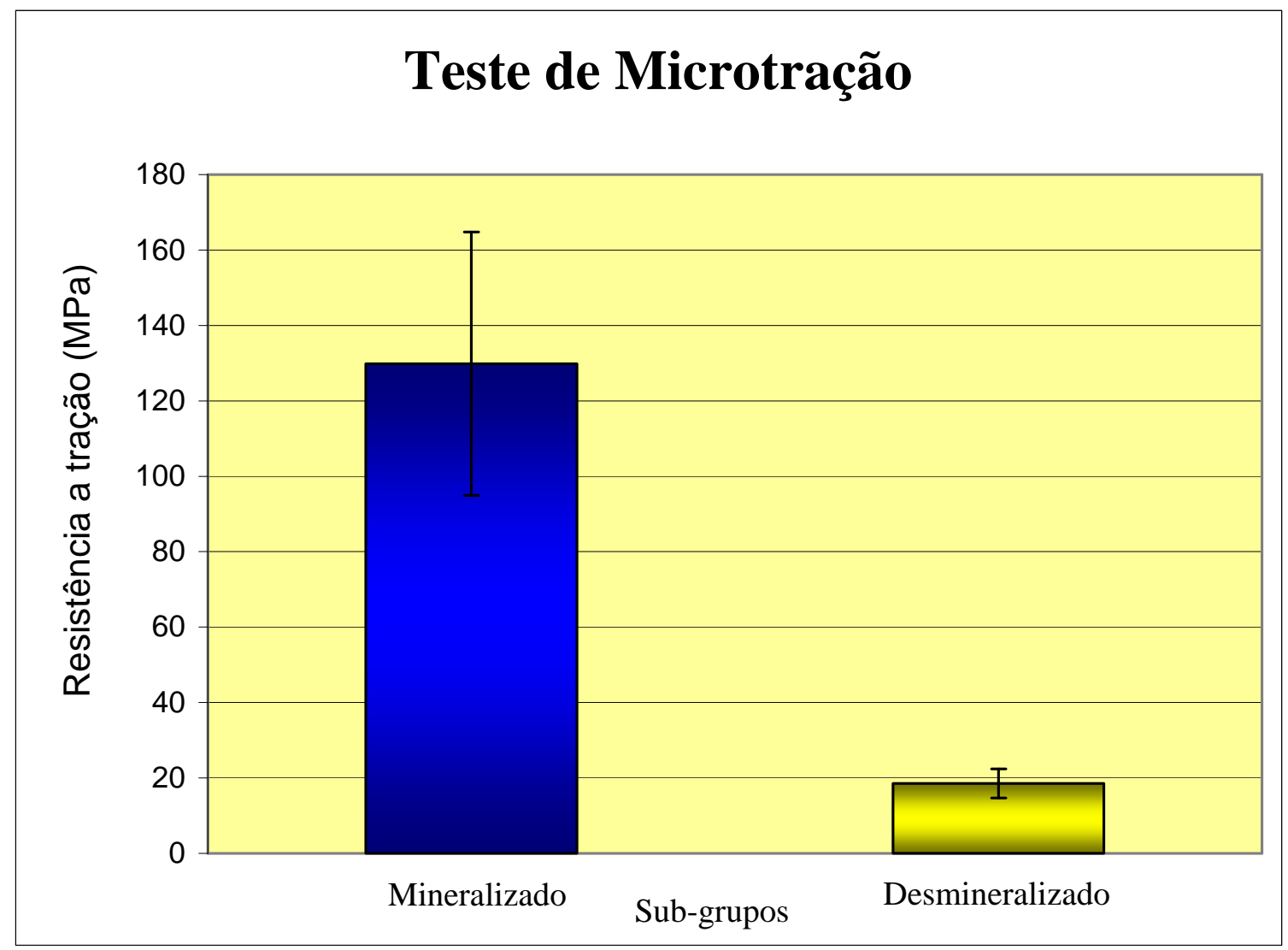

Figura 13 - Representação gráfica dos valores médios, em MPa, da Resistência a Tração para cada sub-grupo. As barras dentro das colunas são representações do desvio padrão. 


\subsection{MÓDULO DE ELASTICIDADE}

Os valores individuais, desvio padrão e as médias do módulo de elasticidade do sub-grupo mineralizado se encontram na Tabela 3 e do subgrupo desmineralizado na Tabela 4. A avaliação dos dados pelo programa estatístico SigmaStat 3.1, demonstrando o teste T de Student para comparação entre os sub-grupos (mineralizado e desmineralizado) está representado pela figura 14, que foi extraído direto do programa SgimaStat 3.1. Na figura 15 há uma melhor visualização dos resultados com as médias e desvio padrão dos grupos através de um gráfico. 
Tabela 3 - Valores individuas para cada espécime do sub-grupo mineralizado frente ao teste de Módulo de Elasticidade, ilustrando o Módulo de Elasticidade ( $\mathrm{MPa})$, Tensão ( $\mathrm{MPa})$, Deformação (\%) e a área de secção transversal $\left(\mathrm{cm}^{2}\right)$.

\begin{tabular}{|c|c|c|c|c|}
\hline Espécime & Módulo (MPa) & Tensão (MPa) & Deformação (\%) & Área $\left(\mathrm{cm}^{2}\right)$ \\
\hline 1 & 1261,7 & 102,83 & 8,15 & 0,0029 \\
\hline 2 & 1372,9 & 108,81 & 7,925 & 0,0027 \\
\hline 3 & 1279,9 & 127,99 & 7,5 & 0,0035 \\
\hline 4 & 1658,8 & 108,155 & 6,52 & 0,002 \\
\hline 5 & 1730,2 & 112,815 & 6,52 & 0,0025 \\
\hline 6 & 1218,2 & 115,365 & 9,47 & 0,0025 \\
\hline 7 & 1704,2 & 114,188 & 6,7 & 0,0025 \\
\hline 8 & 1220,2 & 89,305 & 7,32 & 0,0037 \\
\hline 9 & 1196 & 98,1 & 8,2 & 0,0025 \\
\hline 10 & 1311,2 & 95,327 & 7,27 & 0,0023 \\
\hline 11 & 1146,1 & 113,469 & 9,9 & 0,003 \\
\hline 12 & 1434,1 & 111,435 & 7,77 & 0,0032 \\
\hline Desvio Padrão & 208,3316 & 10,411 & 1,069 & 0,0005 \\
\hline Média & 1377,792 & 108,149 & 7,770 & 0,00278 \\
\hline
\end{tabular}


Tabela 4 - Valores individuas para cada espécime do sub-grupo desmineralizado frente ao teste de Módulo de Elasticidade, ilustrando o Módulo de Elasticidade (MPa), Tensão (MPa), Deformação (\%) e a área de secção transversal $\left(\mathrm{cm}^{2}\right)$.

\begin{tabular}{|c|c|c|c|c|}
\hline Espécime & Módulo (MPa) & Tensão (MPa) & Deformação (\%) & Área $\left(\mathrm{cm}^{2}\right)$ \\
\hline 1 & 58,4104 & 13,04 & 22,32 & 0,0041 \\
\hline 2 & 69,30722 & 16,56 & 23,9 & 0,0061 \\
\hline 3 & 24,87352 & 9,97 & 40,1 & 0,005 \\
\hline 4 & 37,29708 & 12,16 & 32,6 & 0,0052 \\
\hline 5 & 54,06048 & 12,97 & 24 & 0,0031 \\
\hline 6 & 47,16346 & 8,58 & 18,2 & 0,0048 \\
\hline 7 & 41,17874 & 5,95 & 14,45 & 0,0042 \\
\hline 8 & 53,99045 & 12,33 & 22,85 & 0,0033 \\
\hline 9 & 58,4104 & 13,06 & 23,8 & 0,0046 \\
\hline 10 & 43,056076 & 9,78 & 22,01 & 0,0051 \\
\hline 11 & 53,99045 & 13,45 & 23,56 & 0,0048 \\
\hline 12 & 54,3 & 13,24 & 22,98 & 0,0042 \\
\hline Desvio Padrão & 11,2046 & 2,6513 & 6,236733 & 0,000794 \\
\hline Média & 49,66985 & 11,7575 & 24,2308 & 0,00454 \\
\hline
\end{tabular}




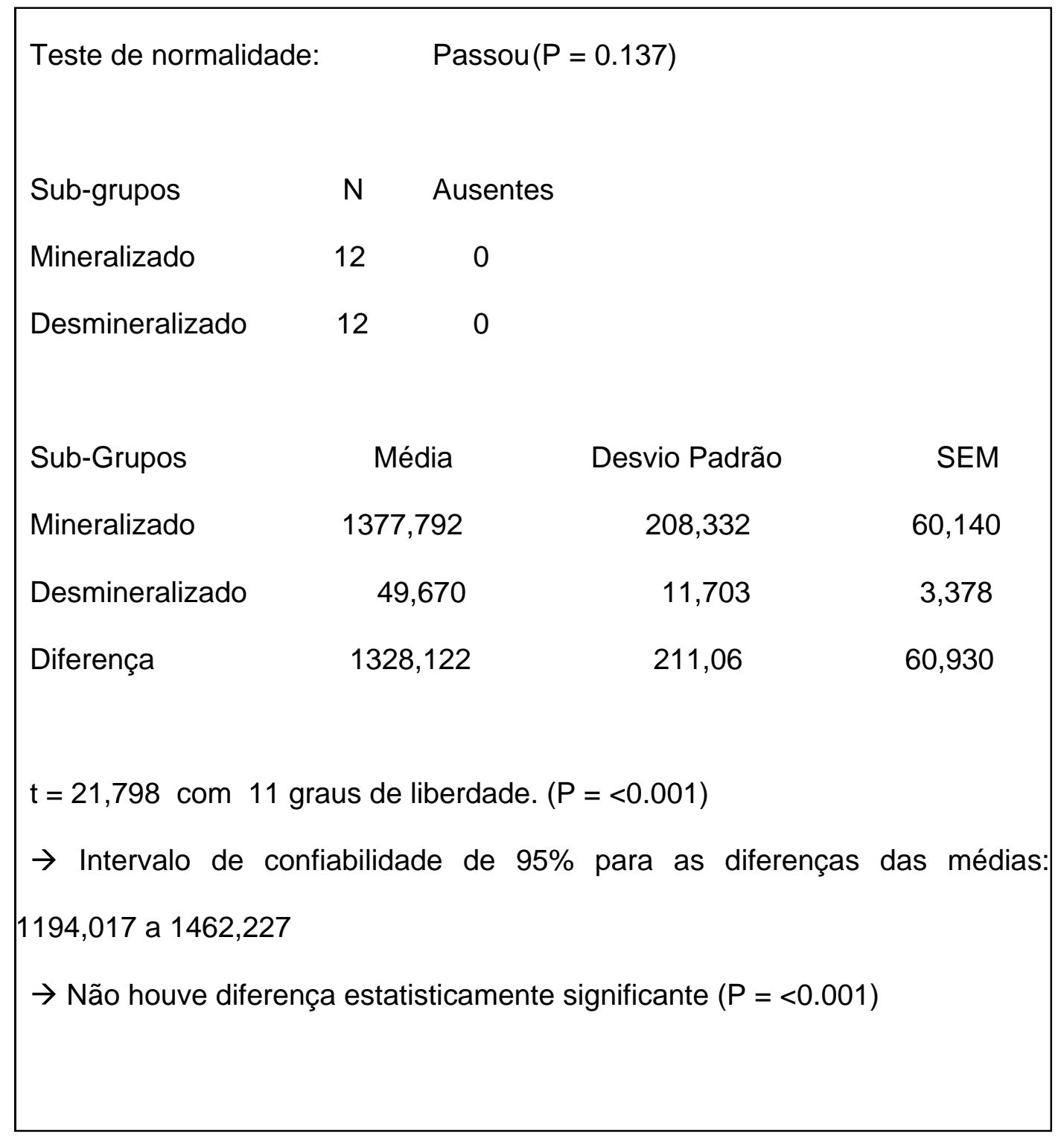

Figura 14 - Análise estatística pelo programa SigmaStat 3,1. Teste T de Student avaliando as Médias, Desvio Padrão, Grau de Liberdade, Intervalo de Confiabilidade e Diferença Estatísicas 


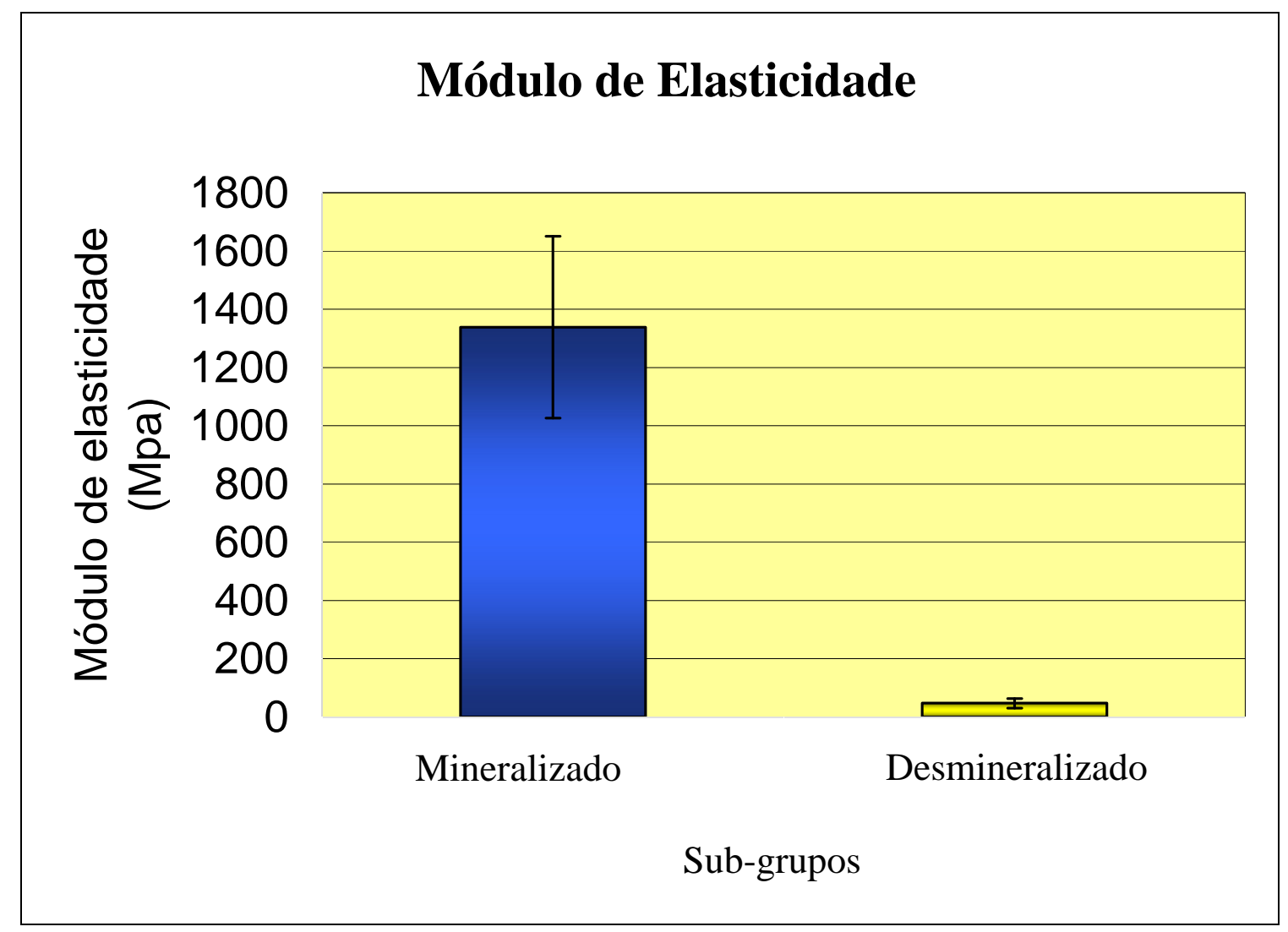

Figura 15 - Representação gráfica dos valores médios, em MPa, do Módulo de Elasticidade para cada grupo. As barras dentro das colunas são representações do desvio padrão. 
A figura 16 representa um modelo comparativo de um espécime de cada sub-grupo (mineralizado e desmineralizado), demonstrando a diferença do padrão da relação tensão x deformação, assim possibilitando observar a diferença entre o módulo de elasticidade de cada grupos

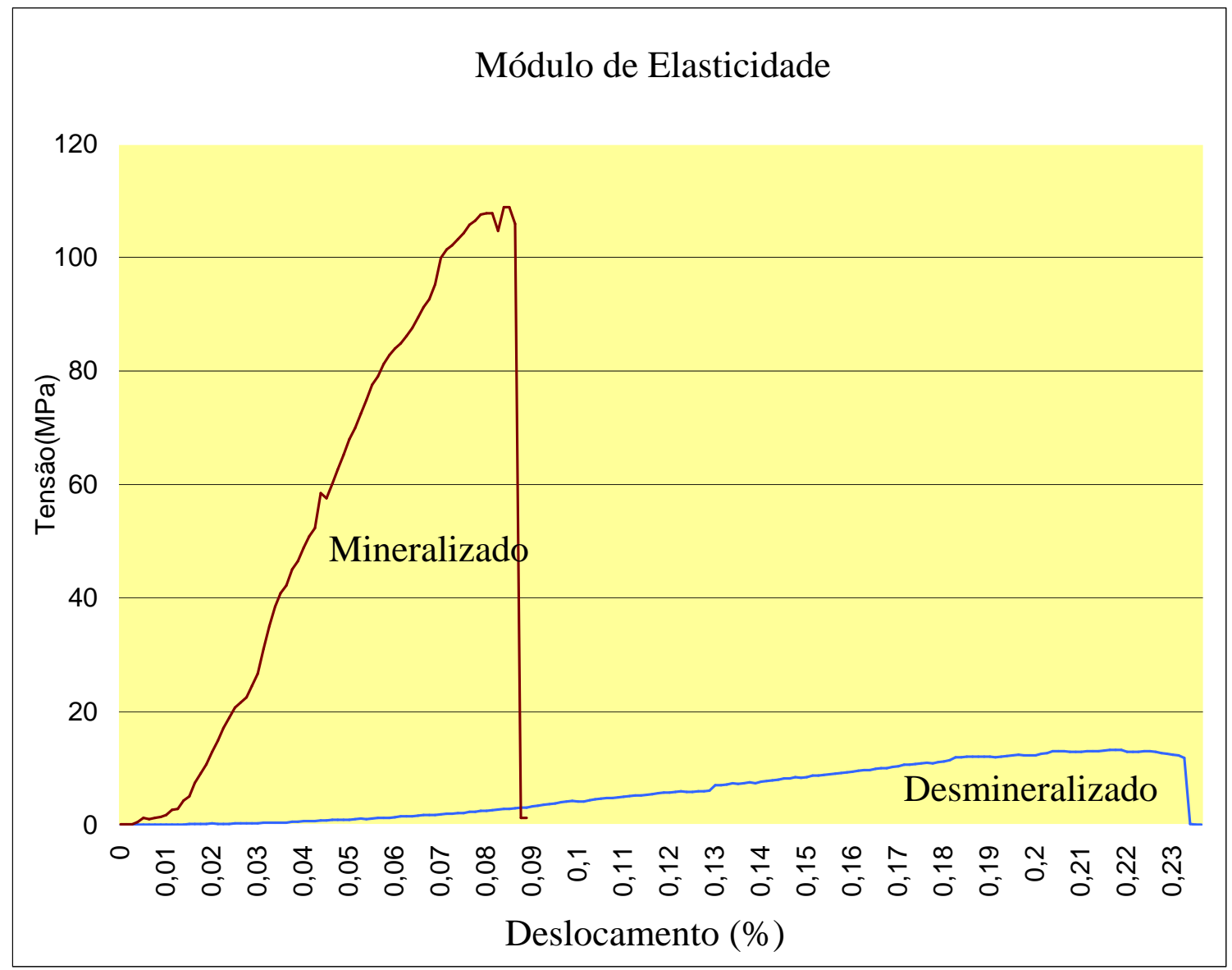

Figura 16 - Representação gráfica de um espécime de cada sub-grupo (mineralizado e desmineralizado) dos valores de tensão em relação ao deslocamento do espécime (\%). 


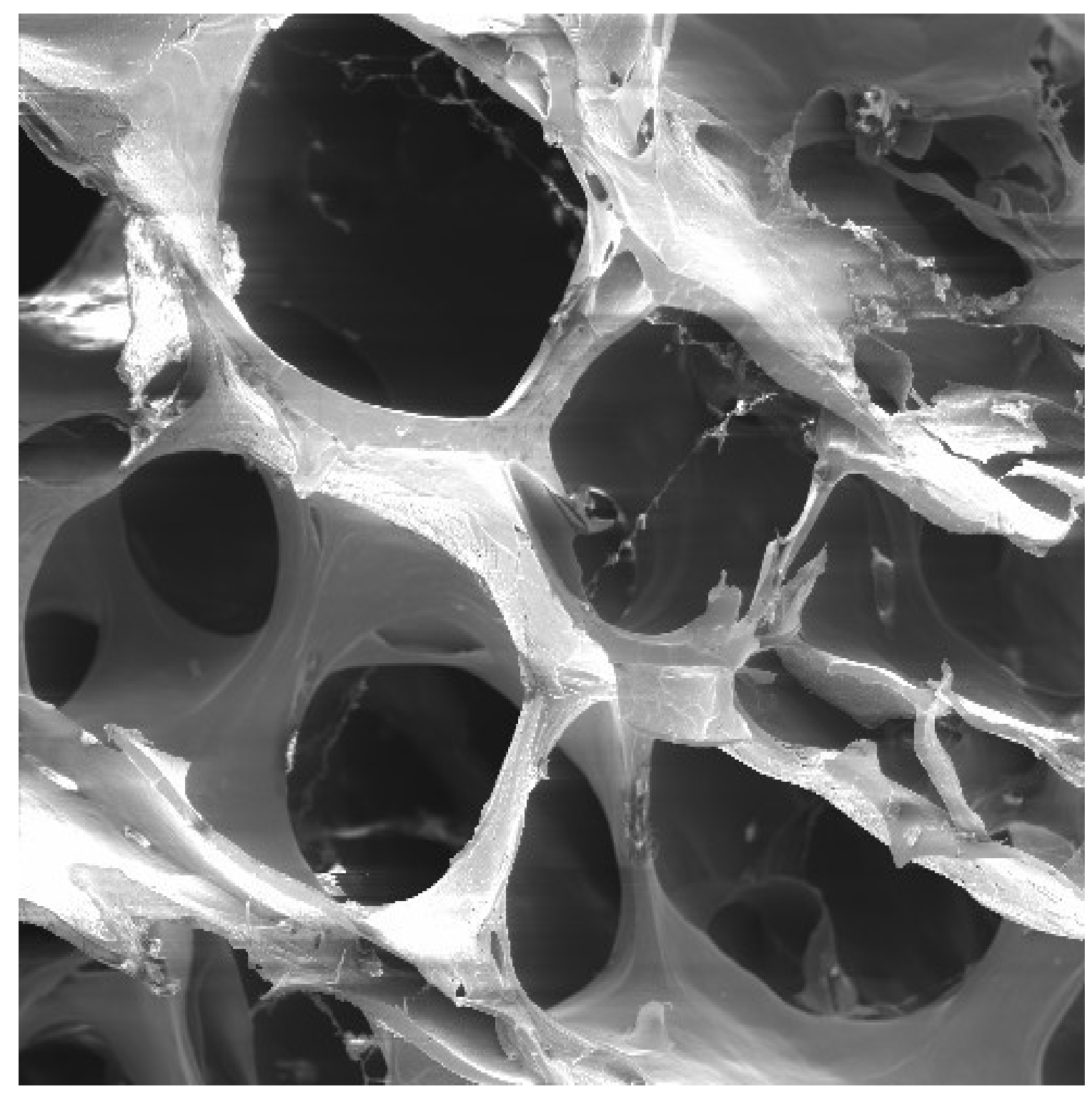

\section{6 - DISCUSSÃO}

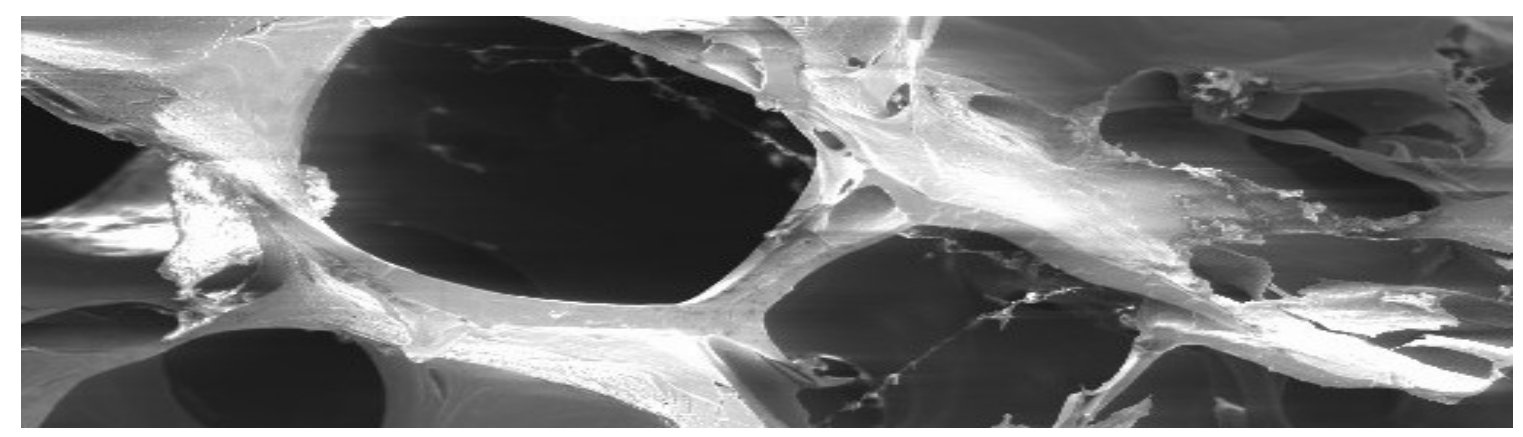




\section{DISCUSSÃO}

A perda do elemento dentário pode desencadear um processo fisiológico de reabsorção óssea alveolar. Esta taxa de reabsorção é bem definida na revisão de literatura para humanos, bem como em animais de laboratório, variando entre a maxila e mandíbula devido a vários fatores sistêmicos (diabetes melitus, osteoporose, doenças sanguíneas) (HOWELL et al. ${ }^{53}, 1997$, JAHANGIRI et al. $.^{57}, 1998$, SCHEER; BOYNE ${ }^{90}, 1987$ ).

À partir do aparecimento do titânio como matéria utilizando na confecção de implantes osseointegrados, os quais são inseridos no tecido ósseo mandibular ou maxilar,tem alavancando o tratamento reabilitador de pacientes total ou parcialmente desdentados. Para a colocação destes implantes há necessidade de certa quantidade de tecido ósseo local, tanto em altura como em espessura para que este possa receber uma prótese e absorver cargas durante o processo de mastigação. Uma alternativa para minimizar a perda óssea decorrente da extração dos dentes é o uso de biomateriais nestes alvéolos, visando a manutenção deste tecido ósseo (quanto em altura como em espessura) (HOWELL et al. $\left.{ }^{53}, 1997\right)$.

A técnica de colocação de um biomaterial no alvéolo é conhecida na periodontia como uma regeneração guiada óssea (ROG), onde se tem como principio a indução de uma formação óssea sem a interferência dos tecidos moles adjacentes aos alvéolos, utilizando-se uma membrana para obstruir essa migração tecidual.

Para avaliação destes biomateriais, principalmente no que concerne à formação óssea (qualidade e quantidade), ostecondução, osteoindução e respostas celulares, um dos modelos experimentais utilizados é a calvária de ratos onde se realizam defeitos críticos ou não nestas áreas, observando-se a resposta do biomaterial quanto ao seu processo biológico restaurador.

Neste estudo foi utilizado este modelo experimental (calvária de ratos) baseado em literatura estudada para os testes mecânicos, visto o grande embasamento cientifico na parte biológica deste modelo, observando-se uma grande gama de biomateriais avaliados, como as BMPs (AHN et al. ${ }^{2}, 2003$, FERREIRA et al. ${ }^{37}, 2004$, HAN et al. ${ }^{48}, 2005$, HONG et al. ${ }^{51}, 2006$, JUNG et 
al. $^{58}$, 2006, LEE et al. ${ }^{62}$, 2003), polímeros (FERREIRA et al. ${ }^{37}, 2004$, FOWLER et al. ${ }^{39}, 2002$, FRANCIS et al. ${ }^{41}, 2003$, HONG et al. ${ }^{51}, 2006$, LEE et al. ${ }^{62}, 2003$, RUPPRECHT et al. ${ }^{87}, 2003$, TAMIMI et al. ${ }^{97}, 2006$, VERHEGGEN; MERTEN ${ }^{109}$, 2001), xenoenxertos (MATZENBACHER et al. ${ }^{67}, 2003$, TAMIMI et al. ${ }^{97}, 2006$ ), membranas (MARDAS; KOSTOPOULOS; KARRING ${ }^{65}, 2002$, TAMURA et al. ${ }^{98}$, 2005, VERNA et al. ${ }^{110}$, 2002), aloenxertos (GLOWACKI; ALTOBELLI; MULLIKEN ${ }^{45}$, 1981, MARDAS; KOSTOPOULOS; KARRING ${ }^{65}$, 2002), PRP (HYUN et al. ${ }^{55}$, 2005, PRYOR; SUSIN; WIKESJO ${ }^{81}$, 2006, PRYOR et al. ${ }^{82}$, 2005). Como método de análise do comportamento da calvária, foi usada uma metodologia denominada teste de microtração, que permite encontrar valores numéricos de resistência à tração e módulo de elasticidade.

Ainda que o método de microtração, quando aplicado ao teste de resistência de união entre materiais odontológicos e a estrutura dental, tenha sido pioneiramente descrito por SANO et al. ${ }^{88}$, 1994, o conceito e o teste em si já foram empregados anteriormente para se testar propriedades mecânicas da dentina (AKHTER; FAN; RHO ${ }^{3}$, 2004, BOWEN; RODRIGUEZ ${ }^{17}$, 1962, SANO et al. $^{88}$, 1994) e osso (RHO; ASHMAN; TURNER ${ }^{83}$, 1993). Embora pareça complexo em sua configuração, aparentemente inaplicável às condições disponíveis nos laboratórios, o conceito e mecânica do teste são verdadeiramente simples. Adotando a mecânica fundamental do teste de tração convencional, adaptando-se as extremidades fixa e móvel da máquina de ensaios para a fixação de um espécime de dimensões reduzidas.

O método de microtração pode ser empregado para se avaliar propriedades mecânicas de substratos como o esmalte (CARVALHO et al. ${ }^{30}$, 1996), dentina (CARVALHO et al. ${ }^{29}$, 2001, SANO et al. ${ }^{88}$, 1994), materiais odontológicos (MENDONCA; SOUZA; CARVALHO ${ }^{69}$, 2003) e propriedades mecânicas ósseas (RHO; ASHMAN; TURNER ${ }^{83}$, 1993). É fundamental entender que a microtração é um método e não um fim, podendo ser adaptado às necessidades de investigação das respectivas hipóteses experimentais levantadas no estudo, desde que as adaptações não comprometam os princípios mecânicos fundamentais do teste. A particularidade do método em permitir testes em áreas de dimensões reduzidas, aliada a uma boa dose de criatividade dos pesquisadores, oferecem a oportunidade de se planejar experimentos que trazem informações inovadoras para a área. As 
possibilidades do método de microtração são inúmeras e incluem vantagens como trabalhar-se com animais com estrutura óssea reduzidas sem a necessidade de uma grande quantidade de animais ou da avaliação em humanos que seria de grande dificuldade devido aos problemas éticos.

Após a remoção das calvárias foram formados dois grupos, mineralizado e desmineralizados, submetidos aos testes de microtração.

Os valores de resistência à fratura encontrados foram de 129,814 \pm 34,9217 MPa para a grupo mineralizado e de 18,547 \pm 3,682 MPa para o desmineralizado. Em um estudo, analisando o comportamento do osso cortical de fêmures e vértebra em humanos, BILEZIKIAN; RAISZ; RODAN ${ }^{14}, 2002$, relataram os valores de resistência encontrados, quanto à direção e tipo de carga utilizada (Tabela).

Tabela 5 - Valores médios do osso humano (adaptação de BILEZIKIAN; RAISZ; $\left.\operatorname{RODAN}^{14}, 2002,\right)$

\begin{tabular}{ccccc}
\hline Tipo de osso & Direção e tipo de carga & $\begin{array}{c}\text { Densidade } \\
\text { aparente } \\
\left(\mathrm{g} / \mathrm{cm}^{3}\right)\end{array}$ & $\begin{array}{c}\text { Resistência/ } \\
\text { tensão } \\
\text { máxima } \\
(\mathrm{MPa})\end{array}$ & $\begin{array}{c}\text { Módulo de } \\
\text { elasticidade } \\
\left(10^{6} \mathrm{MPa}\right)\end{array}$ \\
\hline Cortical & Tensão longitudinal & 1,85 & 133 & 17 \\
(corpo do fêmur) & Compressão longitudinal & 1,85 & 193 & 17 \\
Trabécula & Comsão transversal & 1,85 & 51 & 11,5 \\
(corpo vertebral) & Compressão & 1,85 & 33 & 11,5 \\
\hline
\end{tabular}

Quando se analisa os resultados encontrados neste trabalho, para a resistência à tração do osso mineralizado $(129,814 \pm 34,9217 \mathrm{MPa})$, verifica-se que estes são similares aos encontrados por BILEZIKIAN; RAISZ; RODAN ${ }^{14}$, 2002, quando comparado ao osso cortical do fêmur com uma tensão

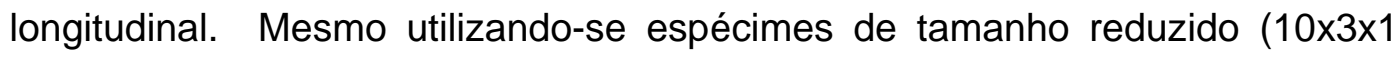
$\mathrm{mm}$ ) os resultados foram semelhantes aos encontrados na literatura (BURSTEIN; REILLY; MARTENS ${ }^{23}$, 1976, CARTER; HAYES ${ }^{28}, 1977$, HERT; FIALA; PETRTYL ${ }^{50}, 1994$, TURNER; CHANDRAN; PIDAPARTI $\left.{ }^{102}, 1995\right)$.

Para o grupo de osso desmineralizado é sabido que sua composição é somente de fibras colágenas podendo levar à uma análise de valores com 
osso trabecular, o qual na sua composição possui uma grande quantidade de colágeno e poucas estruturas minerais. Embora ocorram estas semelhanças suas estruturas são diferentes, limitando as suas comparações.

Esta reflexão e plausível de ser analisada, pois não existem na literatura trabalhos que reforcem comparativamente resultados de osso desmineralizados, quando submetidos à testes de tração.

O módulo de elasticidade descreve a relativa rigidez do material, que é medida pela curva da porção elástica de um gráfico tensão/deformação. Se a carga suportada pelo espécime, dentro do seu limite elástico, for dividida pelo valor correspondente de deformação, uma constante de proporcionalidade será obtida, conhecida como o módulo de elasticidade, módulo flexional, módulo elástico ou módulo de Young. O módulo de elasticidade de um material é uma constante e, ao contrário da resistência flexional, não constitui uma medida de resistência. Segundo ANUSAVICE ${ }^{6}$, 1999, quanto menor for a deformação para um determinado valor de tensão, maior será o valor do módulo de elasticidade. É importante elucidar que o módulo de elasticidade nem sempre está diretamente relacionado com as outras propriedades mecânicas. Dois materiais, por exemplo, podem possuir valores de resistência flexional semelhantes, porém, módulos de elasticidade que se diferem consideravelmente (ANUSAVICE ${ }^{6}, \quad 1999$, HARRISON; HUGGETT; HANDLEY ${ }^{49}$, 1979). Diante destas informações entendemos que a resistência flexional indica a carga suportada pelas regiões mais finas de um determinado material submetido à flexão até a sua deformação permanente. Isto significa que materiais com maior módulo de elasticidade necessitam de uma maior carga para induzir a sua deformação (OGAWA; TANAKA; KOYANO ${ }^{73}, 2000$, UZUN; HERSEK; TINCER $\left.{ }^{105}, 1999\right)$.

Os testes mais utilizados para avaliação do módulo de elasticidade de osso são: microtração (RHO; ASHMAN; TURNER ${ }^{83}$, 1993), nanoedentação (FAN et al. ${ }^{36}$, 2002, RHO et al. ${ }^{84}$, 1997, RHO; PHARR ${ }^{85}$, 1999, TURNER et al. $^{103}, 1999$, ZYSSET et al. ${ }^{114}$, 1999), compressão (ANDREASSEN; MELSEN; OXLUND $^{5}, 1996$, BAYRAKTAR et al. ${ }^{9}, 2004$, HOU et al. $\left.{ }^{52}, 1990\right)$, microscopia acústica (TURNER et al. ${ }^{103}$, 1999), elemento finito/imagens tridimensionais (BECK et al. ${ }^{10}$, 1997, JAASMA et al. ${ }^{56}$, 2002, VAN DER LINDEN; VERHAAR; WEINANS ${ }^{107}, 2001$, VAN RIETBERGEN et al. ${ }^{108}$, 1995) e tensão (BAYRAKTAR 
et al. $^{9}$, 2004). Observa-se, grande quantidade de testes (Tabela 6) e enorme variabilidade nos resultados de módulo de elasticidade, podendo ser explicado pela decorrência a outras variáveis presentes nos diversos estudos, que poderiam interferir positivamente ou negativamente nos resultados.

Tabela 6 - Estudos que avaliaram de alguma forma o módulo de elasticidade.

\begin{tabular}{|c|c|c|c|}
\hline Estudos & $\begin{array}{l}\text { Modelo de } \\
\text { teste }\end{array}$ & $\begin{array}{l}\text { Área utilizada } \\
\text { para o teste }\end{array}$ & Resultados \\
\hline $\mathrm{RHO}$ et al. ${ }^{84}, 1997$ & Nanoedentação & $\begin{array}{l}\text { - Vértebra } \\
\text { humana } \\
\text { - Cortical da } \\
\text { tíbia }\end{array}$ & $\begin{array}{c}13,5 \pm 2,0 \mathrm{GPa} \\
22,5 \pm 1,3 \mathrm{GPa}- \\
\text { Ostéos } \\
25,8 \pm 0,7 \mathrm{GPa}- \\
\text { Lamelas }\end{array}$ \\
\hline $\begin{array}{c}\text { TURNER et al. }{ }^{103}, \\
1999\end{array}$ & Nanoedentação & $\begin{array}{c}\text { - Osso } \\
\text { trabecular } \\
\text { - Osso cortical }\end{array}$ & $\begin{array}{l}18,14 \pm 1,7 \mathrm{GPa} \\
20,02 \pm 0,27 \mathrm{GPa}\end{array}$ \\
\hline $\begin{array}{c}\text { ZYSSET et al. }^{114}, \\
1999\end{array}$ & Nanoedentação & $\begin{array}{c}\text { - Cabeça do } \\
\text { fêmur humano } \\
\text { - Diáfise } \\
\text { humano }\end{array}$ & $\begin{array}{c}6,9 \pm 4,3 \mathrm{GPa} \\
25,0 \pm 4,3 \mathrm{GPa}\end{array}$ \\
\hline $\begin{array}{c}\text { VAN RIETBERGEN } \\
\text { et al. }{ }^{108}, 1995\end{array}$ & Elemento finito & $\begin{array}{l}\text { Trabécula de } \\
\text { humano }\end{array}$ & $2,23 \mathrm{GPa}$ \\
\hline $\begin{array}{c}\mathrm{RHO} ; \mathrm{PHARR}^{85} \\
1999\end{array}$ & Nanoedentação & Cortical bovina & $\begin{array}{c}21,1 \pm 2,0 \text { ostéons } \\
\text { úmidos } \\
25,1 \pm 1,6 \text { lamelas } \\
\text { úmidos } \\
24,4 \pm 2,2 \text { ostéons secos } \\
27,5 \pm 1,2 \text { lamelas secas }\end{array}$ \\
\hline $\begin{array}{l}\text { VAN DER LINDEN; } \\
\text { VERHAAR; } \\
\text { WEINANS }^{107}, 2001\end{array}$ & Imagem 3D & $\begin{array}{c}\text { Osso trabecular } \\
\text { humano }\end{array}$ & \\
\hline FAN et al. ${ }^{36}, 2002$ & nanoedentação & $\begin{array}{c}\text { Cortical da tíbia } \\
\text { humana }\end{array}$ & \\
\hline $\begin{array}{c}\text { BAYRAKTAR et al. }{ }^{9}, \\
2004\end{array}$ & $\begin{array}{c}\text { Tensão } \\
\text { longitudinal }\end{array}$ & $\begin{array}{l}\text { - Trabécula } \\
\text { humana } \\
\text { - Cortical } \\
\text { humana }\end{array}$ & $\begin{array}{l}18,0 \pm 2,8 \mathrm{GPa} \\
19,9 \pm 1,8 \mathrm{GPa}\end{array}$ \\
\hline
\end{tabular}


O módulo de elasticidade encontrado através de um ensaio de microtração neste trabalho foi de $1377,792 \pm 208,3316 \mathrm{MPa}$ para o grupo mineralizado e 49,66985 \pm 11,2046 MPa para o grupo desmineralizado.

Ao observar os resultados $(1377,792 \pm 208,3316 \mathrm{MPa}$ - mineralizado e 49,66985 \pm 11,2046 MPa - desmineralizado) com aqueles encontrados na literatura, foi observado uma diferença entre esses valores, devido à vários fatores como, o tipo de modelo experimental utilizado, pois se sabe que na sua grande maioria os trabalhos nesta área (médica/ortopedia) são realizados em cadáveres (ANDREASSEN; MELSEN; OXLUND ${ }^{5}$, 1996, BAYRAKTAR et al. ${ }^{9}$, 2004, BECK et al. ${ }^{10}$, 1997, FAN et al. ${ }^{36}$, 2002, HOU et al. ${ }^{52}$, 1990, JAASMA et al. ${ }^{56}, 2002$, RHO et al. ${ }^{84}$, 1997, RHO; PHARR ${ }^{85}$, 1999, TURNER et al. ${ }^{103}, 1999$, VAN RIETBERGEN et al. ${ }^{108}$, 1995, ZYSSET et al. ${ }^{114}$, 1999) ou osso de bovinos (JAASMA et al. ${ }^{56}, 2002$ ), pois o interesse destas pesquisas está na resistência à fadiga em osso longos e em áreas reparadas após fraturas. No caso desta pesquisa o foco é de se avaliar e criar um padrão de valor do módulo de elasticidade e resistência em modelos experimentais mais representativos na área odontológica, principalmente na área de enxertia para implantodontia.

Outros fatores que possibilitaram a diferença destes resultados (BAYRAKTAR et al. ${ }^{9}$, 2004, BECK et al. ${ }^{10}$, 1997, FAN; $\mathrm{RHO}^{35}$, 2003, FAN et al. $^{36}, 2002$, JAASMA et al. ${ }^{56}, 2002$, RHO et al. ${ }^{84}$, 1997, RHO; PHARR ${ }^{85}$, 1999, RHO et al. ${ }^{86}, 1999$, TURNER et al. ${ }^{103}$, 1999, VAN DER LINDEN et al. ${ }^{106}, 2001$, VAN RIETBERGEN et al. ${ }^{108}$, 1995, ZYSSET et al. ${ }^{114}$, 1999) podem ser devido à uma grande diversificação de localização da área testada (fêmur, cabeça da tíbia, corpo da tíbia), tipo do osso (medular ou cortical), tipo estrutural (ostéons ou lamelas) e o tipo de teste realizado para obtenção dos valores de módulo de elasticidade.

Os valores de modulo de elasticidade encontrados na literatura são geralmente de espécimes originados da região medular ou cortical dos ossos. Neste trabalho utilizou-se um osso cortical da calvária de ratos, variando somente o tratamento dos espécimes após o sacrifício dos mesmos, diferentemente da literatura que compara a cortical e medular de ossos longos de humanos ou bovinos, dificultando a comparação com os resultados obtidos.

Este trabalho visa não obter valores semelhantes de comparação da literatura e sim valores padrões máximos e mínimos tanto para a resistência 
quanto ao módulo de elasticidade, para que em futuros trabalhos de avaliação do reparo de calvária de ratos com biomateriais, possam ser comparados entre esses padrões, frente à testes mecânicos e não somente testes biológicos.

Estes resultados podem em curto prazo auxiliar a implantodontia necessitando-se, porém outras pesquisas, comparando seus resultados, com agora os desta, que se apresentam como índices comparativos para estas situações. 


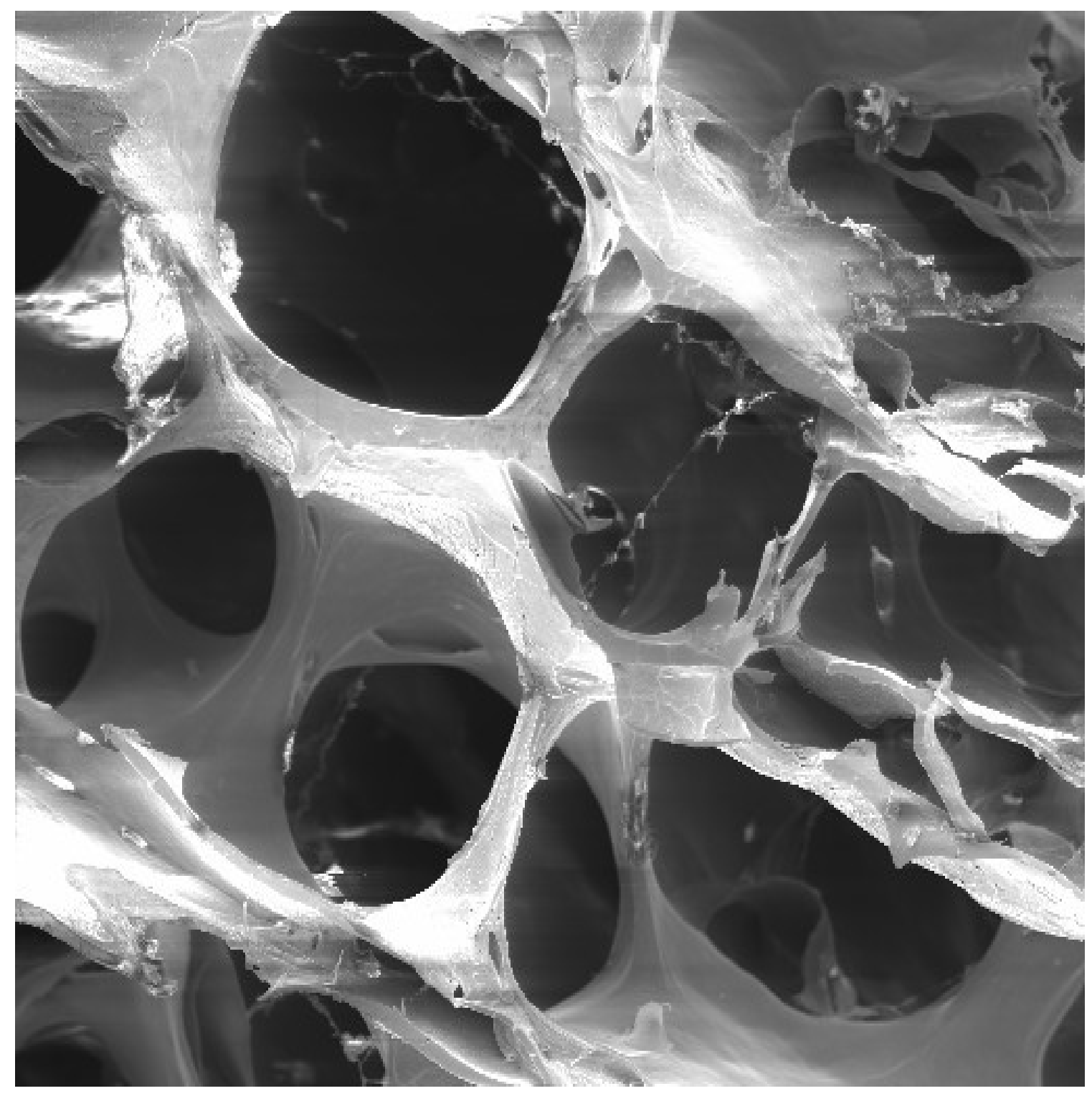

\section{7 - CONCLUSÃO}

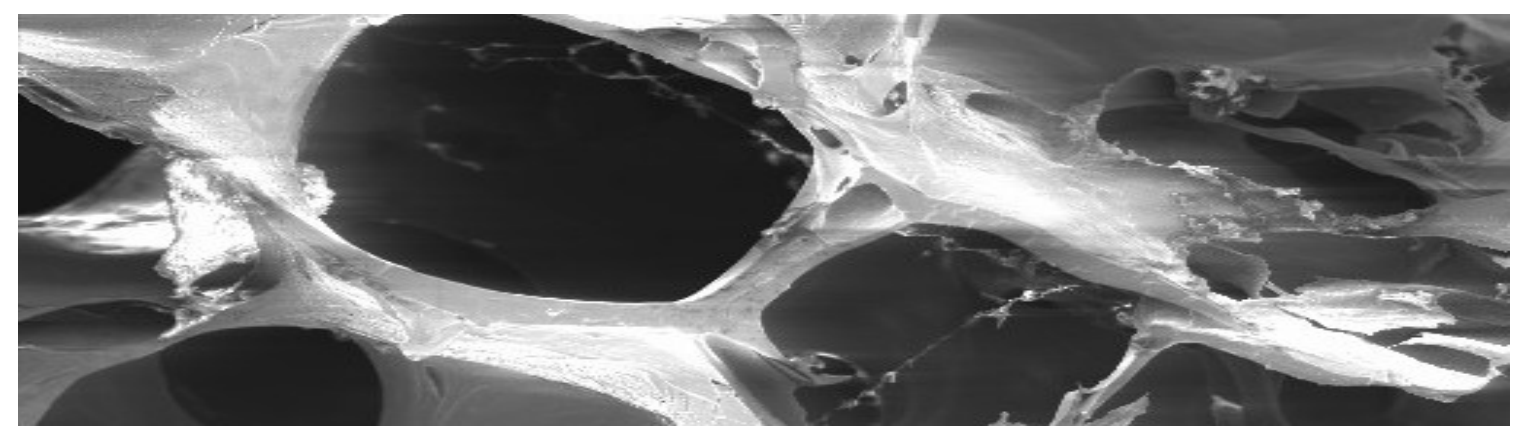




\section{CONCLUSÃO}

Segundo os métodos empregados e com base nos resultados obtidos nas condições laboratoriais deste estudo, podemos concluir que:

a) Sobre a resistência à microtração:

O valor do subgrupo mineralizado foi de 129,814 $\pm 34,9217 \mathrm{MPa}$, sendo estatisticamente maior ( $P=0,001)$ que o grupo desmineralizado com valor de $18,547 \pm 3,682 \mathrm{MPa}$.

b) Sobre o módulo de elasticidade:

Como foi observado na resistência, o módulo de elasticidade do subgrupo mineralizado $(1377,792 \pm 208,331 \mathrm{MPa})$ também foi estatisticamente maior $(P=0,001)$ do que o grupo desmineralizado $(49,669 \pm 11,204$ $\mathrm{MPa})$.

c) Metodologia:

Devido a falta de metodologia na literatura para avaliação de propriedades mecânicas de osso na área odontológica associada com avaliação biológica, este trabalho obteve a determinação de padrões máximos (mineralizado) e mínimos (desmineralizado) das propriedades mecânicas (resistência à microtração e módulo de elasticidade) para possibilitar futuras comparações de áreas enxertadas com diversos biomateriais em calvária de ratos. 


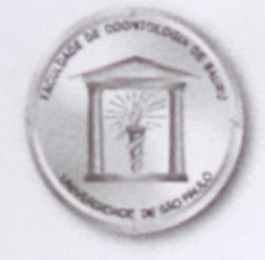

\section{Universidade de São Paulo Faculdade de Odontologia de Bauru}

Al. Dr. Octávio Pinheiro Brisolla, 9-75 - Bauru-SP - CEP 17012-901 - C.P. 73

PABX (0XX14)3235-8000 - FAX (0XX14)3223-4679

Comissão de Ética no Ensino e Pesquisa em Animais

CEEPA-Proc. $N^{\circ} 22 / 2004$

Bauru, 29 de outubro de 2004.

Senhor Professor,

Informamos que após o envio dos esclarecimentos solicitados quanto ao projeto de pesquisa "Análise histomorfométrica e das propriedades mecânicas do fêmur de ratos após implantação de xenoenxertos”, de autoria de Jefferson Tomio Sanada, sob sua orientação, julgado em reunião do dia 06 de outubro de 2004 e novamente avaliado por esta Comissão, somos de parecer favorável à condução do trabalho, uma vez que não apresenta infrações éticas.

Sendo o que nos apresenta para o momento, despedimo-nos,

Atenciosamente,

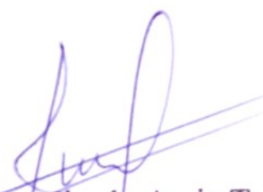

Prof. Dr. Luis Antonio de Assis Taveira

Vice-Presidente da Comissão de Ética no

Ensino e Pesquisa em Animais

Ilm Sr. Prof. Dr. Accácio Lins do Valle

DD. Docente do Departamento de Prótese 
REFERÊNCIAS 


\section{Referências}

1 Aaboe M, Pinholt EM, Hjorting-Hansen E. Healing of experimentally created defects: a review. Br J Oral Maxillofac Surg 1995;33(5):312-8.

2 Ahn SH, Kim CS, Suk HJ, Lee YJ, Choi SH, Chai JK, et al. Effect of recombinant human bone morphogenetic protein-4 with carriers in rat calvarial defects. $\mathbf{J}$ Periodontol 2003;74(6):787-97.

3 Akhter MP, Fan Z, Rho JY. Bone intrinsic material properties in three inbred mouse strains. Calcif Tissue Int 2004;75(5):416-20.

4 Amler $\mathrm{MH}$. The time sequence of tissue regeneration in human extraction wounds. Oral Surg Oral Med Oral Pathol 1969;27(3):309-18.

5 Andreassen TT, Melsen F, Oxlund HT. The influence of growth hormone on cancellous and cortical bone of the vertebral body in aged rats. Journal of Bone and Mineral Research 1996;11:1094-102.

6 Anusavice KJ. Materiais Dentários - Phillips. 10 ed. São Paulo: Guanabara Koogan; 1999.

7 Artzi Z, Nemcovsky CE, Tal H. Efficacy of porous bovine bone mineral in various types of osseous deficiencies: clinical observations and literature review. Int $\mathbf{J}$ Periodontics Restorative Dent 2001;21(4):395-405.

8 Artzi Z, Tal H, Dayan D. Porous bovine bone mineral in healing of human extraction sockets. Part 1: histomorphometric evaluations at 9 months. $\mathbf{J}$ Periodontol 2000;71(6):1015-23.

9 Bayraktar HH, Morgan EF, Niebur GL, Morris GE, Wong EK, Keaveny TM. Comparison of the elastic and yield properties of human femoral trabecular and cortical bone tissue. J Biomech 2004;37(1):27-35.

10 Beck JD, Canfield BL, Haddock SM, Chen TJ, Kothari M, Keaveny TM. Threedimensional imaging of trabecular bone using the computer numerically controlled milling technique. Bone 1997;21(3):281-7.

11 Becker W, Becker BE, Caffesse R. A comparison of demineralized freeze-dried bone and autologous bone to induce bone formation in human extraction sockets. J Periodontol 1994;65(12):1128-33. 
12 Becker W, Clokie C, Sennerby L, Urist MR, Becker BE. Histologic findings after implantation and evaluation of different grafting materials and titanium micro screws into extraction sockets: case reports. J Periodontol 1998;69(4):414-21.

13 Becker W, Lynch SE, Lekholm U, Becker BE, Caffesse R, Donath K, et al. A comparison of ePTFE membranes alone or in combination with platelet-derived growth factors and insulin-like growth factor-I or demineralized freeze-dried bone in promoting bone formation around immediate extraction socket implants. $\mathbf{J}$ Periodontol 1992;63(11):929-40.

14 Bilezikian JP, Raisz LG, Rodan GA. Principles of bone biology 2ed. San Diego Academic Press; 2002.

15 Bonachela WC, Molo JR, Taga EM, Granjeiro JM. Manutenção do rebordo alveolar com hidroxiapatita microgranular. Rev Gaúcha Odont 1992;40:212-4.

16 Bosch C, Melsen B, Vargervik K. Importance of the critical-size bone defect in testing bone-regenerating materials. J Craniofac Surg 1998;9(4):310-6.

17 Bowen RL, Rodriguez MS. Tensile strength and modulus of elasticity of tooth structure and several restorative materials. J Am Dent Assoc 1962;64:378-87.

18 Brandao AC, Brentegani LG, Novaes Junior AB, Grisi MF, Souza SL, Taba Junior $\mathrm{M}$, et al. Histomorphometric analysis of rat alveolar wound healing with hydroxyapatite alone or associated to BMPs. Braz Dent J 2002;13(3):147-54.

19 Buck BE, Malinin TI, Brown MD. Bone transplantation and human immunodeficiency virus. An estimate of risk of acquired immunodeficiency syndrome (AIDS). Clin Orthop Relat Res 1989(240):129-36.

20 Buck BE, Resnick L, Shah SM, Malinin TI. Human immunodeficiency virus cultured from bone. Implications for transplantation. Clin Orthop Relat Res 1990(251):249-53.

21 Burchardt $H$. The biology of bone graft repair. Clin Orthop Relat Res 1983(174):28-42.

22 Burg KJ, Porter S, Kellam JF. Biomaterial developments for bone tissue engineering. Biomaterials 2000;21(23):2347-59.

23 Burstein AH, Reilly DT, Martens M. Aging of bone tissue: mechanical properties. J Bone Joint Surg Am 1976;58(1):82-6.

24 Burstein $\mathrm{AH}$, Wright TM. Fundamentals of orthopaedic biomechanics.: Williams \& Wilkins; 1994. 
25 Burstein FD, Cohen SR, Hudgins R, Boydston W. The use of porous granular hydroxyapatite in secondary orbitocranial reconstruction. Plast Reconstr Surg 1997;100(4):869-74.

26 Calixto RF, Teofilo JM, Brentegani LG, Carvalho TL. Implantation of flakes of castor oil resin in rat dental alveolus. Pesqui Odontol Bras 2001;15(3):257-62.

27 Camargo PM, Lekovic V, Weinlaender M, Klokkevold PR, Kenney EB, Dimitrijevic B, et al. Influence of bioactive glass on changes in alveolar process dimensions after exodontia. Oral Surg Oral Med Oral Pathol Oral Radiol Endod 2000;90(5):581-6.

28 Carter DR, Hayes WC. The compressive behavior of bone as a two-phase porous structure. J Bone Joint Surg Am 1977;59(7):954-62.

29 Carvalho RM, Fernandes CA, Villanueva R, Wang L, Pashley DH. Tensile strength of human dentin as a function of tubule orientation and density. $\mathbf{J}$ Adhes Dent 2001;3(4):309-14.

30 Carvalho RM, Yoshiyama M, Brewer PD, Pashley DH. Dimensional changes of demineralized human dentine during preparation for scanning electron microscopy. Arch Oral Biol 1996;41(4):379-86.

31 Cordioli MAG, Pustiglioni FE, Georgetti MAP. Reparação óssea alveolar pósexodontia em cães, com e sem uso de membrana de PTFE-e - analise histológica. Rev Pós Grad 2000;7:320-7.

32 de Groot K. Bioceramics consisting of calcium phosphate salts. Biomaterials 1980;1(1):47-50.

33 Denissen H, Montanari C, Martinetti R, van Lingen A, van den Hooff A. Alveolar bone response to submerged bisphosphonate-complexed hydroxyapatite implants. J Periodontol 2000;71(2):279-86.

34 Dies F, Etienne D, Abboud NB, Ouhayoun JP. Bone regeneration in extraction sites after immediate placement of an e-PTFE membrane with or without a biomaterial. A report on 12 consecutive cases. Clin Oral Implants Res 1996;7(3):277-85.

35 Fan Z, Rho JY. Effects of viscoelasticity and time-dependent plasticity on nanoindentation measurements of human cortical bone. J Biomed Mater Res A 2003;67(1):208-14. 
36 Fan Z, Swadener JG, Rho JY, Roy ME, Pharr GM. Anisotropic properties of human tibial cortical bone as measured by nanoindentation. J Orthop Res 2002;20(4):806-10.

37 Ferreira GR, Cestari TM, Granjeiro JM, Taga R. Lack of repair of rat skull critical size defect treated with bovine morphometric protein bound to microgranular bioabsorbable hydroxyapatite. Braz Dent J 2004;15(3):175-80.

38 Fisher JP, Lalani Z, Bossano CM, Brey EM, Demian N, Johnston CM, et al. Effect of biomaterial properties on bone healing in a rabbit tooth extraction socket model. J Biomed Mater Res A 2004;68(3):428-38.

39 Fowler EB, Cuenin MF, Hokett SD, Peacock ME, McPherson JC, 3rd, Dirksen TR, et al. Evaluation of pluronic polyols as carriers for grafting materials: study in rat calvaria defects. J Periodontol 2002;73(2):191-7.

40 Frame JW. Hydroxyapatite as a biomaterial for alveolar ridge augmentation. Int J Oral Maxillofac Surg 1987;16(6):642-55.

41 Francis PO, McPherson JC, 3rd, Cuenin MF, Hokett SD, Peacock ME, Billman MA, et al. Evaluation of a novel alloplast for osseous regeneration in the rat calvarial model. J Periodontol 2003;74(7):1023-31.

42 Froum S, Cho SC, Rosenberg E, Rohrer M, Tarnow D. Histological comparison of healing extraction sockets implanted with bioactive glass or demineralized freeze-dried bone allograft: a pilot study. J Periodontol 2002;73(1):94-102.

43 Gamal AY, Mailhot JM, Garnick JJ, Newhouse R, Sharawy MM. Human periodontal ligament fibroblast response to PDGF-BB and IGF-1 application on tetracycline $\mathrm{HCl}$ conditioned root surfaces. J Clin Periodontol 1998;25(5):40412.

44 Gauthier O, Boix D, Grimandi G, Aguado E, Bouler JM, Weiss P, et al. A new injectable calcium phosphate biomaterial for immediate bone filling of extraction sockets: a preliminary study in dogs. J Periodontol 1999;70(4):375-83.

45 Glowacki J, Altobelli D, Mulliken JB. Fate of mineralized and demineralized osseous implants in cranial defects. Calcif Tissue Int 1981;33(1):71-6.

46 Gosain AK. Hydroxyapatite cement paste cranioplasty for the treatment of temporal hollowing after cranial vault remodeling in a growing child. J Craniofac Surg 1997;8(6):506-11. 
47 Haase HR, Clarkson RW, Waters MJ, Bartold PM. Growth factor modulation of mitogenic responses and proteoglycan synthesis by human periodontal fibroblasts. J Cell Physiol 1998;174(3):353-61.

48 Han DK, Kim CS, Jung UW, Chai JK, Choi SH, Kim CK, et al. Effect of a fibrinfibronectin sealing system as a carrier for recombinant human bone morphogenetic protein-4 on bone formation in rat calvarial defects. $\mathbf{J}$ Periodontol 2005;76(12):2216-22.

49 Harrison A, Huggett R, Handley RW. A correlation between abrasion resistance and other properties of some acrylic resins used in dentistry. $\mathbf{J}$ Biomed Mater Res 1979;13(1):23-34.

50 Hert J, Fiala P, Petrtyl M. Osteon orientation of the diaphysis of the long bones in man. Bone 1994;15(3):269-77.

51 Hong SJ, Kim CS, Han DK, Cho IH, Jung UW, Choi SH, et al. The effect of a fibrin-fibronectin/beta-tricalcium phosphate/recombinant human bone morphogenetic protein-2 system on bone formation in rat calvarial defects. Biomaterials 2006;27(20):3810-6.

52 Hou JCH, Salem GJ, Zernicke RF, Barnard RJ. Structural and mechanical adaptations of immature trabecular bone to strenuous exercise. Journal of Applied Physiology 1990;69(4):1309-14.

53 Howell TH, Fiorellini J, Jones A, Alder M, Nummikoski P, Lazaro M, et al. A feasibility study evaluating rhBMP-2/absorbable collagen sponge device for local alveolar ridge preservation or augmentation. Int $\mathbf{J}$ Periodontics Restorative Dent 1997;17(2):124-39.

54 Hunt DR, Jovanovic SA. Autogenous bone harvesting: a chin graft technique for particulate and monocortical bone blocks. Int J Periodontics Restorative Dent 1999;19(2):165-73.

55 Hyun SJ, Han DK, Choi SH, Chai JK, Cho KS, Kim CK, et al. Effect of recombinant human bone morphogenetic protein-2, -4 , and -7 on bone formation in rat calvarial defects. J Periodontol 2005;76(10):1667-74.

56 Jaasma MJ, Bayraktar HH, Niebur GL, Keaveny TM. Biomechanical effects of intraspecimen variations in tissue modulus for trabecular bone. $\mathbf{J}$ Biomech 2002;35(2):237-46. 
57 Jahangiri L, Devlin H, Ting K, Nishimura I. Current perspectives in residual ridge remodeling and its clinical implications: a review. $\mathbf{J}$ Prosthet Dent 1998;80(2):224-37.

58 Jung UW, Choi SY, Pang EK, Kim CS, Choi SH, Cho KS. The effect of varying the particle size of beta tricalcium phosphate carrier of recombinant human bone morphogenetic protein-4 on bone formation in rat calvarial defects. $\mathbf{J}$ Periodontol 2006;77(5):765-72.

59 Koole $\mathrm{R}$, Bosker $\mathrm{H}$, van der Dussen FN. Late secondary autogenous bone grafting in cleft patients comparing mandibular (ectomesenchymal) and iliac crest (mesenchymal) grafts. J Craniomaxillofac Surg 1989;17 Suppl 1:28-30.

60 Lane JM. Biochemistry of fracture repair. Chicago: American Academy of Orthopedic Surgery; 1979.

61 Lane JM. Bone graft substitute. Western J Med 1995:565-67.

62 Lee YM, Nam SH, Seol YJ, Kim TI, Lee SJ, Ku Y, et al. Enhanced bone augmentation by controlled release of recombinant human bone morphogenetic protein-2 from bioabsorbable membranes. J Periodontol 2003;74(6):865-72.

63 Lekovic V, Camargo PM, Klokkevold PR, Weinlaender M, Kenney EB, Dimitrijevic $B$, et al. Preservation of alveolar bone in extraction sockets using bioabsorbable membranes. J Periodontol 1998;69(9):1044-9.

64 Majzoub Z, Berengo M, Giardino R, Aldini NN, Cordioli G. Role of intramarrow penetration in osseous repair: a pilot study in the rabbit calvaria. $\mathbf{J}$ Periodontol 1999;70(12):1501-10.

65 Mardas N, Kostopoulos L, Karring T. Bone and suture regeneration in calvarial defects by e-PTFE-membranes and demineralized bone matrix and the impact on calvarial growth: an experimental study in the rat. $\mathbf{J}$ Craniofac Surg 2002;13(3):453-62; discussion 62-4.

66 Matsuda N, Lin WL, Kumar NM, Cho MI, Genco RJ. Mitogenic, chemotactic, and synthetic responses of rat periodontal ligament fibroblastic cells to polypeptide growth factors in vitro. J Periodontol 1992;63(6):515-25.

67 Matzenbacher SA, Mailhot JM, McPherson JC, 3rd, Cuenin MF, Hokett SD, Sharawy $M$, et al. In vivo effectiveness of a glycerol-compounded demineralized freeze-dried bone xenograft in the rat calvarium. $\mathbf{J}$ Periodontol 2003;74(11):1641-6. 
68 Mellonig JT, Prewett AB, Moyer MP. HIV inactivation in a bone allograft. J Periodontol 1992;63(12):979-83.

69 Mendonca JS, Souza MH, Jr., Carvalho RM. Effect of storage time on microtensile strength of polyacid-modified resin composites. Dent Mater 2003;19(4):308-12.

70 Miller TA, Ishida K, Kobayashi M, Wollman JS, Turk AE, Holmes RE. The induction of bone by an osteogenic protein and the conduction of bone by porous hydroxyapatite: a laboratory study in the rabbit. Plast Reconstr Surg 1991;87(1):87-95.

71 Misch CE, Dietsh F. Bone-grafting materials in implant dentistry. Implant Dent 1993;2(3):158-67.

72 Norton MR, Odell EW, Thompson ID, Cook RJ. Efficacy of bovine bone mineral for alveolar augmentation: a human histologic study. Clin Oral Implants Res 2003;14(6):775-83.

73 Ogawa T, Tanaka M, Koyano K. Effect of water temperature during polymerization on strength of autopolymerizing resin. $\mathbf{J}$ Prosthet Dent 2000;84(2):222-4.

74 Okamoto T, Perri de Carvalho AC, Milanezi LA, Tagliavini RL. Implante de boplant em alvéolo dentais. Rev Fac Odont Araçatuba 1974;3:13-21.

75 Oreffo RO, Triffitt JT. Future potentials for using osteogenic stem cells and biomaterials in orthopedics. Bone 1999;25(2 Suppl):5S-9S.

76 Pang EK, Paik JW, Kim SK, Jung UW, Kim CS, Cho KS, et al. Effects of chitosan on human periodontal ligament fibroblasts in vitro and on bone formation in rat calvarial defects. J Periodontol 2005;76(9):1526-33.

77 Perri de Carvalho AC, Okamoto T, Garcia Jr. IR. Empregos de membrana de teflon para a reparação guiada em exodontia. Rev Gaúcha Odont 1998;3:12731.

78 Pinto LP, Brosco HB, Taga R, Taga EM. Regeneração óssea guiada de alvéolos de extração dentaria: Porque faze-la? Rev Bras Implant 2000:9-12.

79 Poehling S, Pippig SD, Hellerbrand K, Siedler M, Schutz A, Dony C. Superior effect of MD05, beta-tricalcium phosphate coated with recombinant human growth/differentiation factor-5, compared to conventional bone substitutes in the rat calvarial defect model. J Periodontol 2006;77(9):1582-90. 
80 Pryor ME, Polimeni G, Koo KT, Hartman MJ, Gross H, April M, et al. Analysis of rat calvaria defects implanted with a platelet-rich plasma preparation: histologic and histometric observations. J Clin Periodontol 2005;32(9):966-72.

81 Pryor ME, Susin C, Wikesjo UM. Validity of radiographic evaluations of bone formation in a rat calvaria osteotomy defect model. J Clin Periodontol 2006;33(6):455-60.

82 Pryor ME, Yang J, Polimeni G, Koo KT, Hartman MJ, Gross H, et al. Analysis of rat calvaria defects implanted with a platelet-rich plasma preparation: radiographic observations. J Periodontol 2005;76(8):1287-92.

83 Rho JY, Ashman RB, Turner CH. Young's modulus of trabecular and cortical bone material: ultrasonic and microtensile measurements. $\mathbf{J}$ Biomech 1993;26(2):111-9.

84 Rho JY, Flaitz D, Swarnakar V, Acharya RS. The characterization of broadband ultrasound attenuation and fractal analysis by biomechanical properties. Bone 1997;20(5):497-504.

85 Rho JY, Pharr GM. Effects of drying on the mechanical properties of bovine femur measured by nanoindentation. J Mater Sci Mater Med 1999;10(8):485-8.

86 Rho JY, Zioupos P, Currey JD, Pharr GM. Variations in the individual thick lamellar properties within osteons by nanoindentation. Bone 1999;25(3):295300.

87 Rupprecht S, Merten HA, Kessler P, Wiltfang J. Hydroxyapatite cement (BoneSource) for repair of critical sized calvarian defects--an experimental study. J Craniomaxillofac Surg 2003;31(3):149-53.

88 Sano $H$, Shono $T$, Sonoda H, Takatsu T, Ciucchi B, Carvalho R, et al. Relationship between surface area for adhesion and tensile bond strength-evaluation of a micro-tensile bond test. Dent Mater 1994;10(4):236-40.

89 Sano H, Takatsu T, Ciucchi B, Russell CM, Pashley DH. Tensile properties of resin-infiltrated demineralized human dentin. J Dent Res 1995;74(4):1093-102.

90 Scheer P, Boyne PJ. Maintenance of alveolar bone through implantation of bone graft substitutes in tooth extraction sockets. J Am Dent Assoc 1987;114(5):5947. 
91 Sedlin ED. A rheologic model for cortical bone. A study of the physical propertiesof human femoral samples. Acta Orthopaedica Scandinavica 1965;Supplementum 83.

92 Shimano MM, Shimano AC, Volpon JB. Histerese de fêmures de ratas submetidos a ensaios de flexão, em diferentes faixas etárias. Revista Brasileira de Engenharia Biomédica 2002;18(2):89-97.

93 Simpson HE. The healing of extraction wounds. Br Dent J 1969;126(12):550-7.

94 Smukler H, Landi L, Setayesh R. Histomorphometric evaluation of extraction sockets and deficient alveolar ridges treated with allograft and barrier membrane: a pilot study. Int J Oral Maxillofac Implants 1999;14(3):407-16.

95 Stephan EB, Jiang D, Lynch S, Bush P, Dziak R. Anorganic bovine bone supports osteoblastic cell attachment and proliferation. $\mathbf{J}$ Periodontol 1999;70(4):364-9.

96 Tal H. Autogenous masticatory mucosal grafts in extraction socket seal procedures: a comparison between sockets grafted with demineralized freezedried bone and deproteinized bovine bone mineral. Clin Oral Implants Res 1999;10(4):289-96.

97 Tamimi FM, Torres J, Tresguerres I, Clemente C, Lopez-Cabarcos E, Blanco LJ. Bone augmentation in rabbit calvariae: comparative study between Bio-Oss and a novel beta-TCP/DCPD granulate. J Clin Periodontol 2006;33(12):922-8.

98 Tamura T, Fukase Y, Goke E, Yamada Y, Sato S, Nishiyama M, et al. Threedimensional evaluation for augmented bone using guided bone regeneration. $\mathbf{J}$ Periodontal Res 2005;40(3):269-76.

99 Thompson DM. Extraction sites--foundations for restorative excellence. Compend Contin Educ Dent 1999;20(3 Spec No):10-8; quiz 9.

100 Turek SL. Ortopedia: princípios e sua aplicação. São Paulo: Manole LTDA; 1991.

101 Turner $\mathrm{CH}$, Burr DB. Basic biomechanical measurements of bone: a tutorial. Bone 1993;14(4):595-608.

102 Turner $\mathrm{CH}$, Chandran A, Pidaparti RM. The anisotropy of osteonal bone and its ultrastructural implications. Bone 1995;17(1):85-9. 
103 Turner $\mathrm{CH}$, Rho J, Takano Y, Tsui TY, Pharr GM. The elastic properties of trabecular and cortical bone tissues are similar: results from two microscopic measurement techniques. J Biomech 1999;32(4):437-41.

104 Urist MR. Bone: formation by autoinduction. Science 1965;150(698):893-9.

105 Uzun G, Hersek N, Tincer T. Effect of five woven fiber reinforcements on the impact and transverse strength of a denture base resin. $\mathbf{J}$ Prosthet Dent 1999;81(5):616-20.

106 van der Linden JC, Birkenhager-Frenkel DH, Verhaar JA, Weinans $H$. Trabecular bone's mechanical properties are affected by its non-uniform mineral distribution. J Biomech 2001;34(12):1573-80.

107 Van Der Linden JC, Verhaar JA, Weinans H. A three-dimensional simulation of age-related remodeling in trabecular bone. J Bone Miner Res 2001;16(4):68896.

108 van Rietbergen B, Weinans $H$, Huiskes $R$, Odgaard A. A new method to determine trabecular bone elastic properties and loading using micromechanical finite-element models. J Biomech 1995;28(1):69-81.

109 Verheggen R, Merten HA. Correction of skull defects using hydroxyapatite cement (HAC)--evidence derived from animal experiments and clinical experience. Acta Neurochir (Wien) 2001;143(9):919-26.

110 Verna C, Dalstra M, Wikesjo UM, Trombelli L. Healing patterns in calvarial bone defects following guided bone regeneration in rats. A micro-CT scan analysis. $\mathbf{J}$ Clin Periodontol 2002;29(9):865-70.

111 Wenz B, Oesch B, Horst M. Analysis of the risk of transmitting bovine spongiform encephalopathy through bone grafts derived from bovine bone. Biomaterials 2001;22(12):1599-606.

112 Wozney JM. The potential role of bone morphogenetic proteins in periodontal reconstruction. J Periodontol 1995;66(6):506-10.

113 Zhao YF, Mendes M, Symington JM, Listrom RD, Pritzker KP. Experimental study of bone growth around a dental implant after Surgibone grafting. Int J Oral Maxillofac Implants 1999;14(6):889-97.

114 Zysset PK, Guo XE, Hoffler CE, Moore KE, Goldstein SA. Elastic modulus and hardness of cortical and trabecular bone lamellae measured by nanoindentation in the human femur. J Biomech 1999;32(10):1005-12. 


\begin{abstract}
Evaluation of the resistance and modulus of elasticity of bone mineralized and desmineralized for the tests of microtensile.
\end{abstract}

The loss of the alveolar bone as resulted of periodontal illness or second to the surgery is sources of innumerable complications for the surgeons dentists, and the solution for such problem if it bases on regenerative procedures. Regeneration is made through bone grafts that establish one scaffold for the tecidual repairing, increasing bone fabrics in the resultant defects of trauma or surgeries, filling the alveolous after extraction to preserve the height and thickness of the alveolar rigde and being increased and/or reconstructing the alveolar rigde. These procedures are carried through the use of autogenous, alografts, aloplastic or xenogenics grafts, having each one its characteristics and indications. With the development of the osseointegrated implants, it was seen necessity to keep a good amount and bone quality. This project has as objective to evaluate the resistance the traction and modulus of elasticity of the mineralized bone and desmineralized. of calvarium of rats, similar to determine initial standards (maximum and minimum) for comparisons with possible biomateriais of fulfilling of osteoinduction and osteoconduction. 24 animals divided in 2 groups had been used. Group $1(n=12)$ : modulus of elasticity being that we will use the two parietals of the animal, having made possible 24 specimens, subdivided in mineralized $(n=12)$ and desmineralized $(n=12)$. Group $2(n=12)$ : microtraction, being that 12 hemi-calvarium had been used for 12 the desmineralized sub-group and the others hemi-calvarium for the mineralized sub-group. After the death of the animals, the specimens will be collected and treated in accordance with the sub-group (mineralized and desmineralized). The tests had been carried through in a machine of universal test (Vitrodyme, V1000). The resistance averages the traction of the mineralized one was mineralized 129,814 $\pm 34.921 \mathrm{MPa}$ and the desmineralized one was $18,547 \pm 3,682 \mathrm{MPa}$. For the modulus of elasticity we got values of $1377,792 \pm 208.331 \mathrm{MPa}$ for the mineralized group and 49,669 $\pm 11,204$ $\mathrm{MPa}$ for the desmineralized group, when comparing the resistance and modulus of elasticity the traction between the desmineralized and mineralized sub-group observes a estatistical significant difference for the mineralized group $(p<0,001)$. 
Concluded that the microtraction test can be used to evaluate the mechanical properties in this biological experimental model.

Keywords: Dental Implants. Bone. Biocompatible Materials. 